\title{
Categorization of Used Nuclear Fuel Inventory in Support of a Comprehensive National Nuclear Fuel Cycle Strategy
}

December 2012

\section{Prepared by} John C. Wagner, ORNL Joshua L. Peterson, ORNL Don E. Mueller, ORNL Jess C. Gehin, ORNL Andrew Worrall, ORNL Temitope Taiwo, ANL Mark Nutt, ANL Mark A. Williamson, ANL Mike Todosow, BNL Roald Wigeland, INL William G. Halsey, LLNL Ronald P. Omberg, PNNL Peter N. Swift, SNL Joe T. Carter, SRNL

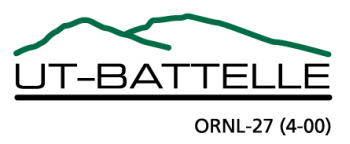




\section{DOCUMENT AVAILABILITY}

Reports produced after January 1, 1996, are generally available free via the U.S. Department of Energy (DOE) Information Bridge.

Web site http://www.osti.gov/bridge

Reports produced before January 1, 1996, may be purchased by members of the public from the following source.

National Technical Information Service

5285 Port Royal Road

Springfield, VA 22161

Telephone 703-605-6000 (1-800-553-6847)

TDD 703-487-4639

Fax 703-605-6900

E-mail info@ntis.gov

Web site http://www.ntis.gov/support/ordernowabout.htm

Reports are available to DOE employees, DOE contractors, Energy Technology Data Exchange (ETDE) representatives, and International Nuclear Information System (INIS) representatives from the following source.

Office of Scientific and Technical Information

P.O. Box 62

Oak Ridge, TN 37831

Telephone 865-576-8401

Fax 865-576-5728

E-mail reports@osti.gov

Web site http://www.osti.gov/contact.html

This report was prepared as an account of work sponsored by an agency of the United States Government. Neither the United States Government nor any agency thereof, nor any of their employees, makes any warranty, express or implied, or assumes any legal liability or responsibility for the accuracy, completeness, or usefulness of any information, apparatus, product, or process disclosed, or represents that its use would not infringe privately owned rights. Reference herein to any specific commercial product, process, or service by trade name, trademark, manufacturer, or otherwise, does not necessarily constitute or imply its endorsement, recommendation, or favoring by the United States Government or any agency thereof. The views and opinions of authors expressed herein do not necessarily state or reflect those of the United States Government or any agency thereof. 
ORNL/TM-2012/308

FCRD-FCT-2012-000232

Reactor and Nuclear Systems Division

\title{
CATEGORIZATION OF USED NUCLEAR FUEL INVENTORY IN SUPPORT OF A COMPREHENSIVE NATIONAL NUCLEAR FUEL CYCLE STRATEGY
}

\author{
John C. Wagner, Joshua L. Peterson, Don E. Mueller, Jess C. Gehin, Andrew Worrall \\ Oak Ridge National Laboratory \\ Temitope Taiwo, Mark Nutt, Mark A. Williamson \\ Argonne National Laboratory \\ Mike Todosow \\ Brookhaven National Laboratory \\ Roald Wigeland \\ Idaho National Laboratory \\ William G. Halsey \\ Lawrence Livermore National Laboratory \\ Ronald P. Omberg \\ Pacific Northwest National Laboratory \\ Peter N. Swift \\ Sandia National Laboratories \\ Joe T. Carter \\ Savannah River National Laboratory
}

Date Published: December 2012

Prepared by

OAK RIDGE NATIONAL LABORATORY

Oak Ridge, Tennessee 37831-6283

managed by

UT-BATTELLE, LLC

for the

U.S. DEPARTMENT OF ENERGY

under contract DE-AC05-00OR22725 



\section{CONTENTS}

Page

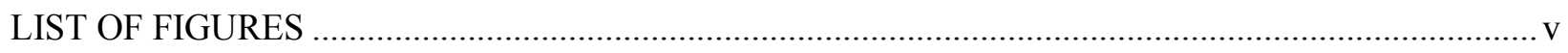

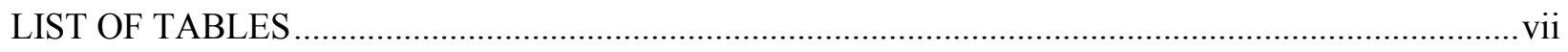

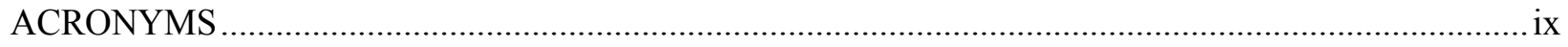

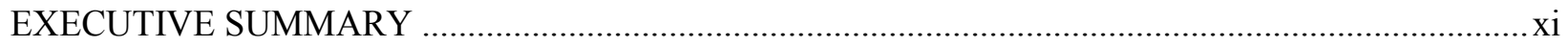

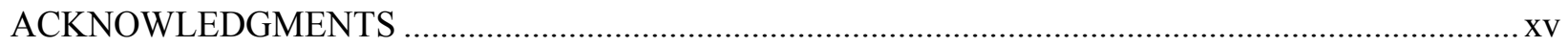

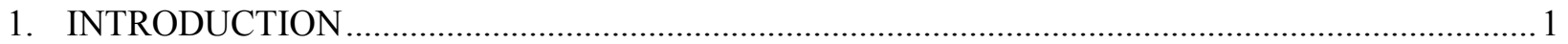

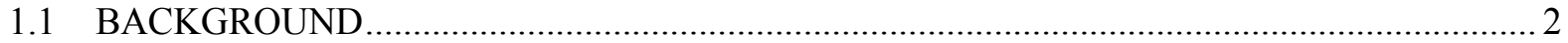

2. OVERVIEW OF THE DOMESTIC USED NUCLEAR FUEL INVENTORY ...............................5

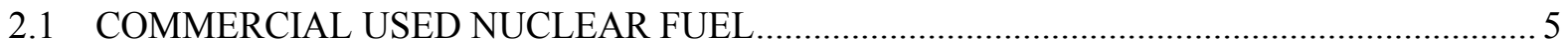

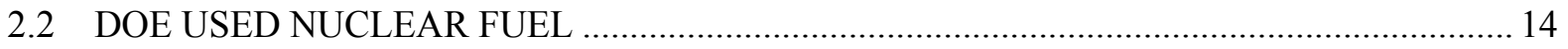

2.3 HIGHLY ENRICHED URANIUM USED NUCLEAR FUEL ........................................... 15

3. ASSESSMENT OF USED NUCLEAR FUEL RELATIVE TO RETENTION NEEDS ................... 17

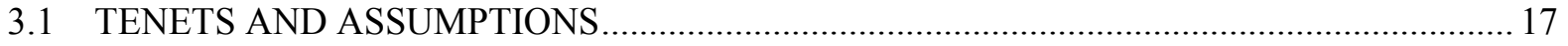

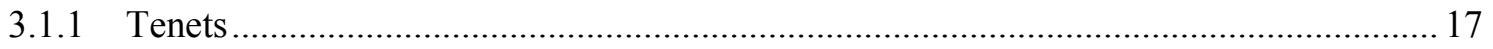

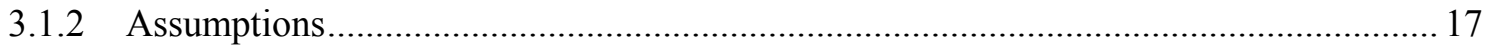

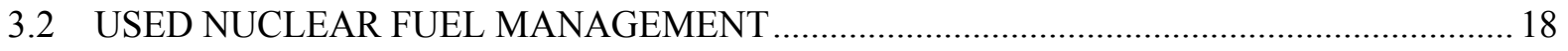

3.2.1 Used Nuclear Fuel Material Need.................................................................................. 18

3.2.2 Selection Criteria for Used Nuclear Fuel ................................................................... 19

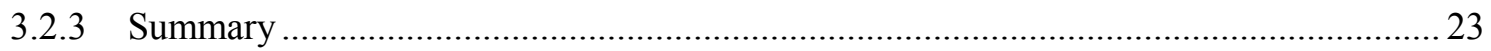

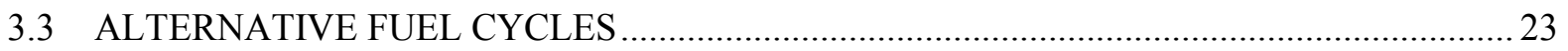

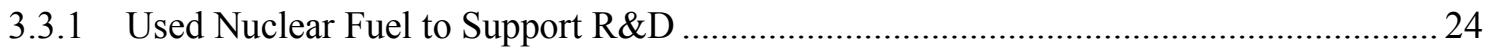

3.3.2 Used Nuclear Fuel to Support Recycle Fuel Cycle Deployment ...................................28

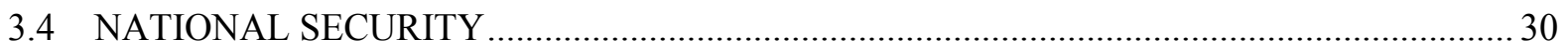

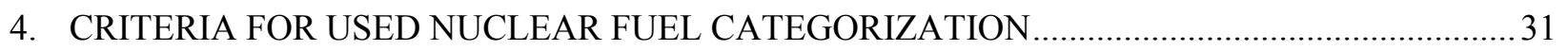

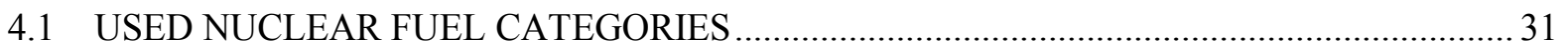

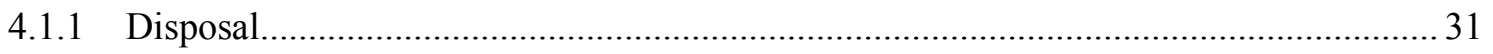

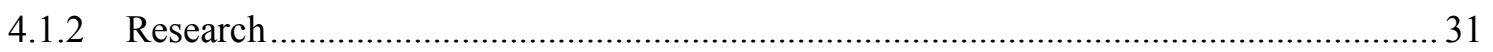

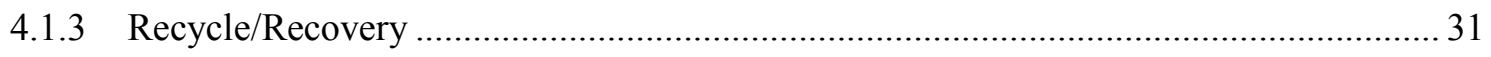

4.2 ATTRIBUTES AND ISSUES AFFECTING CATEGORIZATION ......................................... 31

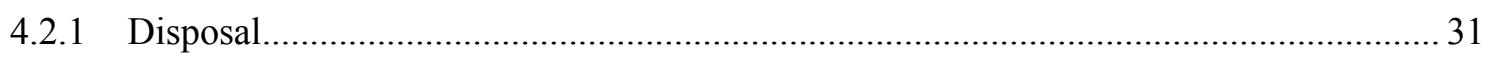

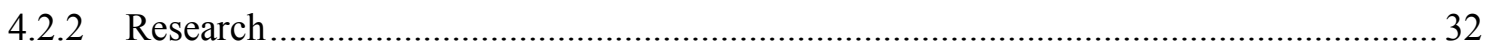




\section{CONTENTS (continued)}

Page

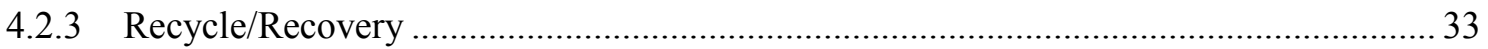

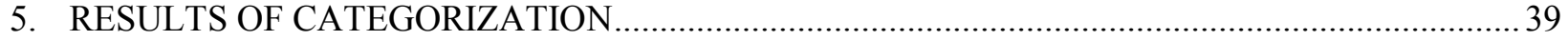

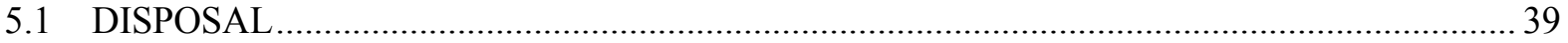

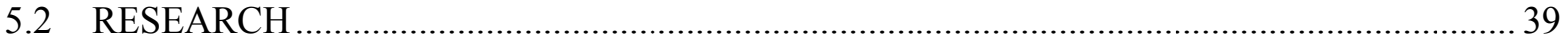

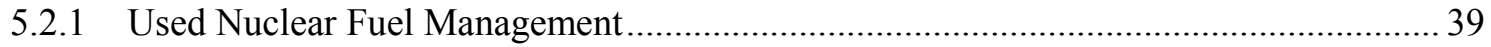

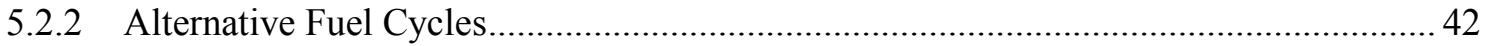

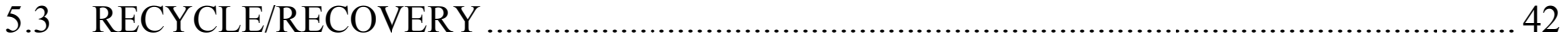

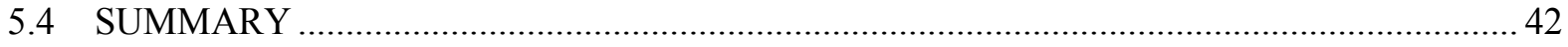

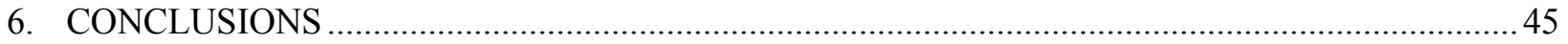

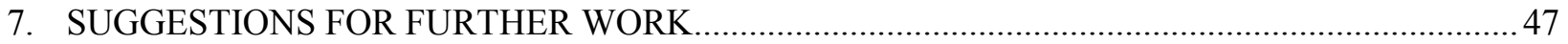

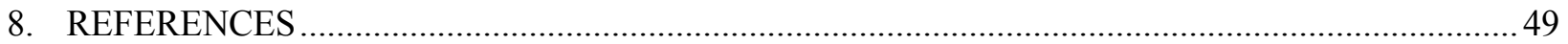

APPENDIX A: COMMERCIAL USED NUCLEAR FUEL CHARACTERISTICS ............................ A-1

APPENDIX B: DOE-OWNED USED NUCLEAR FUEL CHARACTERISTICS ............................. B-1 


\section{LIST OF FIGURES}

Page

Figure ES-1. Categorization of UNF assuming current discharge rate and recycling beginning in 2030 xiii

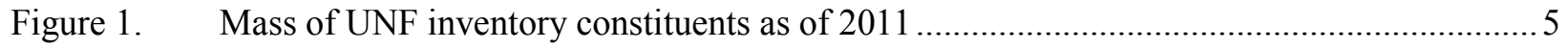

Figure 2. Operating and shutdown commercial reactor sites ...................................................... 6

Figure 3. Distribution of current (2011) commercial UNF inventory from PWRs and BWRs in wet and dry storage.....

Figure 4. Distribution (through 2002) of assembly lattice sizes by mass (units are percentage of total MTHM) in the commercial UNF inventory 8

Figure 5. Distribution (through 2002) of fuel vendors by mass (units are percentage of total MTHM) in the commercial UNF inventory.....

Figure 6. Distribution of assembly classes by total mass in the commercial UNF inventory as of 2002

Figure 7. Distribution of PWR fuel assembly types by mass (units of MTHM) in the commercial UNF inventory as of 2002

Figure 8. Distribution of BWR fuel assembly types by mass (units of MTHM) in the commercial UNF inventory as of 2002

Figure 9. Assembly-average initial enrichment as a function of time ............................................ 12

Figure 10. Assembly-average discharge burnup as a function of time............................................. 12

Figure 11. PWR assembly class discharges as a function of time through 2002 ............................... 13

Figure 12. BWR assembly class discharges as a function of time through 2002 ............................. 13

Figure 13. Distribution of assembly average burnup for all PWR and BWR fuel assemblies

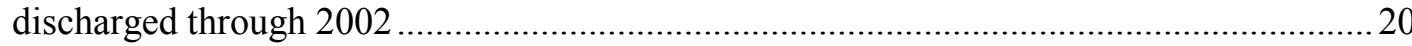

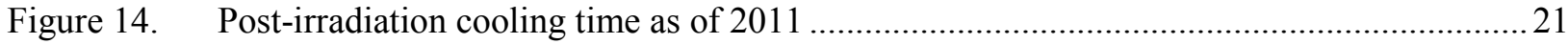

Figure 15. Historical and projected discharges of commercial used nuclear fuel ...............................22

Figure 16. Plutonium-239 equivalence for a thermal reactor as a function of burnup, discharged date, and reactor type .26

Figure 17. Plutonium-239 equivalence for a fast reactor as a function of burnup, discharged date, and reactor type

Figure 18. Categorization of UNF assuming current discharge rate and recycling beginning in 2030

Figure 19. Predicted number of light water reactors and fast reactors required to match potential nuclear growth scenario

Figure 20. Discharge isotopic composition of a WE $17 \times 17$ assembly with initial enrichment of $4.5 \mathrm{wt} \%$ that has accumulated $45 \mathrm{GWd} / \mathrm{MTU}$ burnup.

Figure 21. Isotopic composition of used nuclear fuel as a function of burnup for a generic PWR $17 \times 17$ assembly for zero cooling time. 


\section{LIST OF FIGURES (continued)}

Page

Figure 22. Distribution of assembly initial uranium mass by assembly class in the commercial UNF inventory as of 2002 ...... 36

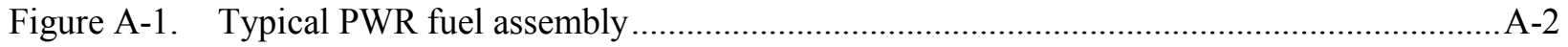

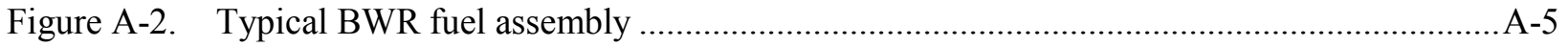




\section{LIST OF TABLES}

Page

Table 1. Estimated mass of UNF for which access should be retained to support UNF management R\&D 41

Table 2. Summary of UNF categorization results (units are MTHM) ......................................... 43

Table A-1. Physical characteristics of pressurized water reactor assembly classes .......................... A-3

Table A-2. Physical characteristics of boiling water reactor assembly classes ................................. A-6

Table A-3. Assembly types and their main characteristics as of December 31, 2002 .......................A-9

Table A-4. Summary of UNF characteristics from which representative samples may be selected.

Table A-5. Summary of UNF characteristics from which representative samples may be selected for PWR fuel assemblies.

Table A-6. Summary of UNF characteristics from which representative samples may be selected for BWR fuel assemblies.

Table B-1. Ranges of nominal properties for DOE-owned used nuclear fuel. 



\section{ACRONYMS}

\begin{tabular}{|c|c|}
\hline $\mathrm{AC}$ & Allis Chalmers \\
\hline ANF & Advanced Nuclear Fuels \\
\hline APSRA & axial power shaping rod assembly \\
\hline $\mathrm{B} \& \mathrm{~W}$ & Babcock and Wilcox \\
\hline BPRA & burnable poison rod assemblies \\
\hline BWR & boiling water reactor \\
\hline $\mathrm{CE}$ & Combustion Engineering \\
\hline $\mathrm{COL}$ & Combined (construct and operate) license \\
\hline DOE & Department of Energy \\
\hline DOE-EM & Department of Energy, Office of Environmental Management \\
\hline DOE-NE & Department of Energy, Office of Nuclear Energy \\
\hline EPA & Environmental Protection Agency \\
\hline EPRI & Electric Power Research Institute \\
\hline FCT & Fuel Cycle Technologies \\
\hline GA & General Atomics \\
\hline GE & General Electric \\
\hline GNF & Global Nuclear Fuels \\
\hline GWd & gigawatt-day \\
\hline HEU & highly enriched uranium \\
\hline INL & Idaho National Laboratory \\
\hline ISFSI & independent spent fuel storage installations \\
\hline LWR & light water reactor \\
\hline MOX & mixed oxide \\
\hline MTHM & metric ton of heavy metal \\
\hline MTU & metric ton uranium \\
\hline MWd & megawatt-day \\
\hline NFS & Nuclear Fuel Services \\
\hline NRC & Nuclear Regulatory Commission \\
\hline NU & Northeast Utilities \\
\hline NWTRB & Nuclear Waste Technical Review Board \\
\hline PWR & pressurized water reactor \\
\hline RCCA & rod control cluster assembly \\
\hline R\&D & research and development \\
\hline RD\&D & research, development, and demonstration \\
\hline UFDC & Used Fuel Disposition Campaign \\
\hline UNC & United Nuclear Corporation \\
\hline UNF & used nuclear fuel \\
\hline WE & Westinghouse Electric \\
\hline wt $\%$ & weight percent \\
\hline
\end{tabular}





\section{EXECUTIVE SUMMARY}

The Department of Energy's Office of Fuel Cycle Technologies (FCT) in the Office of Nuclear Energy (DOE-NE) has conducted a technical review and assessment of the total current inventory

[ 70,150 MTHM (metric ton of heavy metal) as of 2011] of domestic discharged used nuclear fuel (UNF) and estimated that up to 1700 MTHM of existing commercial UNF should be considered for retention to support research, development, and demonstration (RD\&D) needs and national security interests. The 70,150 MTHM includes commercial ( 67,600 MTHM), highly enriched uranium (HEU) ( 50 MTHM), and DOE-owned ( 2500 MTHM) UNF. The remainder, $\sim 68,450$ MTHM (both DOE-owned and commercial UNF) or $\sim 98 \%$ of the total current inventory by mass, can proceed to permanent disposal without the need to ensure retrievability for reuse or research purposes. The assumptions used for this assessment are consistent with the DOE-NE R\&D Roadmap; "specifically, the time to complete the needed RD\&D places commercial reprocessing availability no sooner than the 2030 time frame. This assessment does not assume any decision about future fuel cycle options or preclude any potential options, including those with potential recycling of commercial UNF, since the 2000 MTHM that is generated annually could provide the feedstock needed for deployment of alternative fuel cycles; for example, by 2030 an additional 40,000 MTHM of commercial UNF will have been generated.

The technical assessment considered discharged UNF from commercial nuclear electricity generation and defense and research programs and divided the current (as of 2011) UNF inventory into the following three categories:

1. Disposal - excess material that is not needed for other purposes;

2. Research - material needed for RD\&D purposes to support waste management (e.g., UNF storage, transportation, and disposal) and development of alternative fuel cycles (e.g., separations and advanced fuels); and

3. Recycle/Recovery - material with inherent and/or strategic value.

As a result of consideration of RD\&D needs within the DOE-NE programs, time frames in which recycle fuel cycles could be deployed, projections for electricity and nuclear growth, and possible uses to support national security interests, it is proposed that the vast majority of the total UNF inventory should be placed in the first category and permanently disposed, without the need to make fuel retrievable from disposal for reuse or research purposes. It is proposed that material in the latter two categories should be retained to support ongoing and planned RD\&D needs and national security interests. The amount of material designated for retention includes a sufficient margin to provide assurance that future retrievability from disposal will not be necessary for reuse or research purposes.

Key tenets and assumptions used in this technical assessment include the following.

1. Access to some amount of UNF is needed to support RD\&D for the DOE-NE FCT program objectives related to UNF management and alternative fuel cycles.

2. The two principal options for addressing UNF management are geologic disposal and recycling.

3. U.S. nuclear power plants will continue to discharge 2000 MTHM annually for the next couple of decades; projections beyond the next couple of decades are less certain.

\footnotetext{
${ }^{*}$ Nuclear Energy Research and Development Roadmap, Report to Congress, U.S. Department of Energy, Office of Nuclear Energy, Washington, DC, April 2010, http://www.ne.doe.gov/pdfFiles/NuclearEnergy_Roadmap_Final.pdf.
} 
4. The option of recycling commercial UNF at a future date is maintained, pending a decision.

5. Although fuel recycling depends on future decisions, it is assumed that industrial-scale (100s to $1000 \mathrm{~s}$ of MTHM/y) recycling of commercial UNF is unlikely to begin for at least 20 years (2030 time frame), at which time an additional 40,000 MTHM of UNF will have been discharged.

6. Recycling in any potential future alternative fuel cycle would likely be designed and optimized for the material needs of the associated reactor fleet based on the current and projected UNF discharges and inventory at that time, rather than UNF feedstock that is no longer being produced.

7. The time frame for the development of alternative fuel cycles is assumed to be consistent with the schedule in the DOE-NE R\&D Roadmap.

8. It is assumed that the transportation and placement of the current UNF inventory in disposal is unlikely to begin for at least 10 years and will take several decades.

The current inventory of domestic UNF is massive, diverse, dispersed, and increasing. Approximately $67,600 \mathrm{MTHM}$ of commercial UNF, representing a total of $\sim 23$ billion curies of long-lived radioactivity, ${ }^{\dagger}$ $\sim 2500$ MTHM of DOE-owned UNF, and 50 MTHM of HEU UNF are currently stored at 79 sites in 34 states. The commercial UNF inventory is currently increasing annually by $\sim 2000 \mathrm{MTHM}^{\ddagger}$ and will increase at a greater rate in the future if nuclear power generation increases. Reactor and fuel designs, as well as reactor operating conditions, have evolved in the United States since the first commercial development of nuclear power, resulting in considerable variation in the characteristics (e.g., fuel assembly and cladding materials, initial enrichment, discharge burnup, and irradiation exposure conditions) of the current UNF inventory. These variations may raise issues with aspects of nuclear fuel management, for example, demonstrating compliance with storage, transportation, and disposal regulatory criteria for all the variations present in the current UNF inventory.

The technical assessment of the domestic UNF inventory included a set of attributes relative to permanent geologic disposal, UNF research needs, deployment of alternative fuel cycles, and national security materials strategy and then used the attributes to categorize the current UNF inventory. Attributes considered include isotopic compositions (e.g., fissile and non-fissile content), physical and material characteristics that impact recycling and/or disposal facility design and operations (e.g., accessibility of material, diversity of material, condition of material, and material hazards), national security materials strategy, and current and projected RD\&D needs to support UNF management and alternative fuel cycle development. Consideration was given to the fact that since the United States is generating 2000 MTHM annually, disposal of the majority of the current commercial UNF does not preclude the option of recycling commercial UNF at a future date. For example, assuming the current discharge rate remains constant, if the United States built and began operation of an industrial-scale reprocessing facility with annual capacity of up to 2000 MTHM by 2030 that used 5-year-cooled fuel, a portion of the discharged UNF would not need to be retained to support this facility until 2025.

\footnotetext{
*Spent Nuclear Fuel: Accumulating Quantities at Commercial Reactors Present Storage and Other Challenges, GAO-12-797, U.S. Government Accountability Office, August 2012.

${ }^{\dagger}$ J. T. Carter, A. J. Luptak, and J. Gastelum, Fuel Cycle Potential Waste Inventory for Disposition, FCR\&D-USED-2010000031 REV 5, U.S. Department of Energy, July 2012.

${ }^{\ddagger}$ Effects of a Termination of the Yucca Mountain Repository Program and Lessons Learned, GAO-11-229, U.S. Government Accountability Office, April 2011.
} 
An example projection of the identified material for disposal and retention (research and recycle) on a per-decade basis is provided in Figure ES-1. This figure shows the total current UNF inventory in 2011 and designates all but $\sim 1700$ MTHM for disposal. For UNF generated in subsequent decades, the figure identifies the material for disposal and retention assuming a constant discharge rate of $2000 \mathrm{MTHM} / \mathrm{y}$ and a recycling strategy implemented by 2030 . Note that UNF is systematically retained for RD\&D purposes prior to 2025 , after which the UNF is retained principally for recycling. This example is just one possible scenario and is only provided to illustrate the point that disposal of the current UNF inventory will not adversely impact deployment of an alternative fuel cycle in the future, even for a recycle fuel cycle.

Based on the technical assessment, $\sim 68,450$ MTHM or $\sim 98 \%$ of the total current inventory by mass, can proceed to permanent disposal without the need to ensure retrievability for reuse or research purposes.

Execution of the DOE-NE's Office of FCT mission * requires immediate and continued access to select UNF material for research purposes. Access to this material is needed to support the development of the safety basis for extended storage of commercial UNF and transportation following extended storage periods (e.g., commercial UNF with varying cladding materials and exposure conditions may be needed to address long term fuel integrity) and disposal (e.g., a range of uranium oxide fuel may be needed to demonstrate how UNF degrades in various environments). Additionally, access to material is needed for RD\&D to support development of potential future alternative fuel cycles. As recommended by the Blue Ribbon Commission on America's Nuclear Future, ${ }^{\dagger}$ fuel cycle R\&D activities are critical to maintaining "Active U.S. leadership in international efforts to address safety, waste management, non-proliferation, and security concerns."

HEU UNF may be useful to support national security missions and represents a small fraction of the current UNF inventory (up to $\sim 50 \mathrm{MTHM}$ ). This material represents U.S.-origin enriched uranium that is not subject to international consent agreements. For example, it could be used to offset the need for a dedicated enrichment plant to support national security missions. Given the special nature of this material, it is recommended that a study be conducted to evaluate the benefits of recovering this material.

In conclusion, an assessment of the UNF inventory and the RD\&D needs has estimated that access to $\sim 1700$ MTHM of the existing commercial UNF inventory should be retained to support the DOE-NE FCT mission. The quantity was determined based on projected RD\&D needs and practical considerations for access to a sufficient quantity of representative samples of the diverse commercial UNF inventory to

\footnotetext{
*"to develop used nuclear fuel management strategies and technologies to support meeting federal government responsibility to manage and dispose of the nation's commercial used nuclear fuel and high-level waste; develop sustainable fuel cycle technologies and options that improve resource utilization and energy generation, and reduce waste generation, enhance safety, and limit proliferation risk."

${ }^{\dagger}$ Blue Ribbon Commission on America's Nuclear Future, Report to the Secretary of Energy, January 2012, http://brc.gov/sites/default/files/documents/brc finalreport jan2012.pdf.
} 
support UNF storage, transportation, and disposal; access to high-burnup UNF representative of future discharges in quantities sufficient to support fuel cycle technology development; and a sufficient margin to provide assurance that future retrievability from disposal will not be necessary. The main conclusion of this assessment is not the specific amounts or specific assemblies for retention and disposal but rather that access to some small fraction of the existing UNF should be retained, while the remainder can proceed to disposal without the need to ensure retrievability for reuse or research purposes. Because a repository is not anticipated to be available for more than a decade, time is available to refine, if needed, the specific amounts and select specific assemblies as the RD\&D programs proceed and the associated UNF material needs are better defined.

Finally, note that categorization of UNF for disposal does not require a determination that it has no value. In principle, all irradiated fuel has some potential value as an energy source. The determination instead supports a comprehensive national fuel cycle strategy. 


\section{ACKNOWLEDGMENTS}

This work was supported by the Department of Energy Office of Nuclear Energy's (DOE-NE) Office of Fuel Cycle Technologies (FCT). The authors gratefully acknowledge the initiation of this study by Monica Regalbuto and the subsequent guidance and review throughout the performance of this work by Monica Regalbuto, John Herczeg, Jeff Williams, and Pete Lyons of DOE-NE. The authors also gratefully acknowledge the thoughtful reviews of the draft report by Robert Howard and Cecil Parks of Oak Ridge National Laboratory, Burton Richter of Stanford Linear Accelerator Center, Everett L. Redmond II of the Nuclear Energy Institute, Andrew Sowder of the Electric Power Research Institute, and the U.S. Nuclear Waste Technical Review Board. Finally, the authors are grateful to Debbie Weaver for document preparation and formatting and Debbie Stevens for editorial review of this report. 



\section{INTRODUCTION}

This report documents a technical review and assessment of the current inventory of domestic discharged used nuclear fuel (UNF) in support of a comprehensive national nuclear fuel cycle strategy. The objective of the review and assessment is to determine if the domestic UNF inventory can be separated into different, distinguishable categories relative to disposition options and, if so, to quantitatively differentiate the UNF inventory relative to the defined categories. This assessment is consistent with the Department of Energy Office of Nuclear Energy's (DOE-NE) Fuel Cycle Technologies (FCT) Office mission, "to develop used nuclear fuel management strategies and technologies to support meeting federal government responsibility to manage and dispose of the nation's commercial used nuclear fuel and high-level waste; develop sustainable fuel cycle technologies and options that improve resource utilization and energy generation, and reduce waste generation, enhance safety, and limit proliferation risk," and is motivated by the recognition that characterization and categorization of the domestic UNF inventory can inform decisions relative to domestic disposition options and UNF management. For example, if a certain fraction of the UNF inventory is determined to be excess material that is not needed for other purposes, that information can clarify needs for geologic disposal, such as capacity and retrievability, as well as impact how and where that material is handled and stored in the future.

Alternatively, if a certain fraction is determined to be useful for recycling, that knowledge can clarify needs for future reprocessing facilities, such as capacity and other facility characteristics, as well as how and where the UNF is handled and stored, including the importance of assembly integrity and retrievability. The scope of this assessment includes the current (as of 2011) inventory of discharged UNF from commercial nuclear electricity generation and defense and research programs.

The current inventory of domestic UNF is massive, diverse, dispersed, and increasing. Although the UNF inventory has been and continues to be managed safely, it represents a significant financial liability. The two principal options for addressing UNF management are geologic disposal and recycling, which also requires geologic disposal for resulting high-level waste. Given the current mass [ 70,150 MTHM (metric ton of heavy metal)] and diversity of the domestic UNF inventory and the fact that U.S. nuclear power plants are discharging 2000 MTHM annually, it is difficult to conceive a realistic or financially viable alternative nuclear fuel cycle in which the current inventory would need to be retained for reuse. On the other hand, geologic disposal of the entire current inventory would reduce and potentially eliminate access to UNF that may be needed to support UNF management and alternative fuel cycle research, development, and demonstration (RD\&D). Therefore, the focus of this assessment is on the determination of the characteristics and amounts of UNF that should be retained for potential future use and those that should be designated for disposal.

The assessment approach includes the following:

1. Collection and analysis of current and projected UNF inventory data;

2. Assessment of the UNF inventory relative to retention needs for RD\&D, potential future recycle, and recovery for national security interests;

3. Determination of appropriate categories and criteria for categorizing the UNF inventory; and

4. Categorization of the UNF inventory relative to the identified categories.

Key tenets and assumptions include the following.

1. Access to some amount of UNF is needed to support RD\&D for the DOE-NE FCT program objectives related to UNF management and alternative fuel cycles. 
2. The two principal options for addressing UNF management are geologic disposal and recycling.

3. U.S. nuclear power plants will continue to discharge 2000 MTHM annually for the next couple of decades; projections beyond the next couple of decades are less certain.

4. The option of recycling commercial UNF at a future date is maintained, pending a decision.

5. Although fuel recycling depends on future decisions, it is assumed that industrial-scale (100s to $1000 \mathrm{~s}$ of MTHM/y) recycling of commercial UNF is unlikely to begin for at least 20 years (2030 time frame), at which time an additional 40,000 MTHM of UNF will have been discharged.

6. Recycling in any potential future alternative fuel cycle would likely be designed and optimized for the material needs of the associated reactor fleet based on the current and projected UNF discharges and inventory at that time, rather than UNF feedstock that is no longer being produced.

7. The time frame for the development of alternative fuel cycles is assumed to be consistent with the schedule in the DOE-NE R\&D Roadmap.

8. It is assumed that the transportation and placement of the current UNF inventory in disposal is unlikely to begin for at least 10 years and will take several decades.

This report is organized as follows. Relevant background information is provided in Section 1.1. An overview of the domestic UNF inventory is presented in Section 2. Section 3 provides an assessment of the UNF relative to retention needs. Section 4 defines the categories and criteria used for categorizing the UNF inventory. Section 5 presents the results of the categorization. Conclusions and suggestions for future work are described in Sections 6 and 7, respectively.

\subsection{BACKGROUND}

In 2010, the DOE-NE developed a research and development (R\&D) roadmap ${ }^{2}$ to ensure nuclear energy remains a viable energy option for the United States. The DOE-NE Roadmap identified the following key challenges to the increased use of nuclear energy.

- "The capital cost of new large plants is high and can challenge the ability of electric utilities to deploy new nuclear power plants.

- The exemplary safety performance of the U.S. nuclear industry over the past thirty years must be maintained by an expanding reactor fleet.

- There is currently no integrated and permanent solution to high-level nuclear waste management.

- International expansion of the use of nuclear energy raises concerns about the proliferation of nuclear weapons stemming from potential access to special nuclear materials and technologies."

To address the challenges to expanding the use of nuclear energy, the DOE-NE Roadmap organized the $R \& D$ activities along the following four main $R \& D$ objectives.

1. Develop technologies and other solutions that can improve the reliability, sustain the safety, and extend the life of current reactors.

2. Develop improvements in the affordability of new reactors to enable nuclear energy to help meet the Administration's energy security and climate change goals.

3. Develop sustainable nuclear fuel cycles.

4. Understand and minimize the risks of nuclear proliferation and terrorism.

As described in the DOE-NE Roadmap, sustainable fuel cycle options are those that improve uranium resource utilization, maximize energy generation, minimize waste generation, improve safety, and limit 
proliferation risk. The key challenge identified in the DOE-NE Roadmap is to develop a suite of options that will enable future decision makers to make informed choices about how best to manage the used fuel from reactors. Hence, according to the DOE-NE Roadmap, DOE will conduct R\&D in this area to investigate the technical challenges involved with the following three potential strategies for used fuel management.

- "Once-Through - Nuclear fuel makes a single pass through a reactor after which the used fuel is removed, stored for some period of time, and then directly disposed in a geologic repository for long-term isolation from the environment. The used fuel will not undergo any sort of treatment to alter the waste form prior to disposal in this approach, eliminating the need for separations technologies that may pose proliferation concerns. Less than one percent of the mined uranium is utilized in the present once-through fuel cycle.

- Modified Open Cycle - The goal of this approach is to develop fuel for use in reactors that can increase utilization of the fuel resource and reduce the quantity of actinides that would be disposed in used fuel. This strategy is "modified" in that some limited separations and fuel processing technologies are applied to the used LWR fuel to create fuels that enable the extraction of much more energy from the same mass of material and accomplish waste management goals.

- Full Recycle - In a full recycle strategy, all of the actinides important for waste management are recycled in thermal- or fast-spectrum systems to reduce the radiotoxicity of the waste placed in a geologic repository while more fully utilizing uranium resources. In a full recycle system, only those elements that are considered to be waste (primarily the fission products) are intended for disposal, not used fuel. Implementing this system will require extensive use of separation technologies and the likely deployment of new reactors or other systems capable of transmuting actinides."

The R\&D to support future decisions is to be conducted during the next few decades to support the FCT Program Vision: "By mid-century, strategies and technologies for the safe long-term management and eventual disposal of U.S. commercial UNF and any associated nuclear wastes have been fully implemented." The technical assessment described in this report is part of the FCT R\&D program and is intended to support near-term and future decisions regarding fuel cycle strategies and R\&D needs. Between now and mid-century, 40 years of additional discharged commercial UNF could be accumulated, which, based on the current annual discharge rate, could be as much as 80,000 MTHM of additional UNF. While in theory all $80+$ years of UNF could be recycled, the practicalities, cost, and potential benefits of doing so must be properly considered. Therefore, the UNF inventory is assessed in this report to determine the type and quantity of UNF that may be needed to support the DOE-NE research objectives, including maintaining the fuel cycle strategy options described above. The focus of this assessment is on the determination of the characteristics and amounts of UNF that should be retained for potential future use and those that should be designated for permanent disposal.

*It is recognized that the annual discharge rate may vary considerably over the next 40 years. 



\section{OVERVIEW OF THE DOMESTIC USED NUCLEAR FUEL INVENTORY}

The current (as of 2011) domestic UNF inventory includes UNF from commercial nuclear electricity generation and defense and research programs stored at 79 sites in 34 states. The diversity of UNF types, characteristics, storage locations, and storage conditions presents a variety of challenges to the safety, security, and cost of UNF management. The current mass of fuel in each of the categories is shown in Figure 1. The inventory of discharged commercial UNF is currently $\sim 67,600 \mathrm{MTHM}^{3}$ and is increasing by $\sim 2000$ MTHM annually. ${ }^{4}$ The inventory of DOE-owned UNF is currently $\sim 2500$ MTHM and is not increasing at an appreciable annual rate. The inventory of HEU is currently 50 MTHM. Additional details on these UNF inventory constituents are provided in the following subsections.

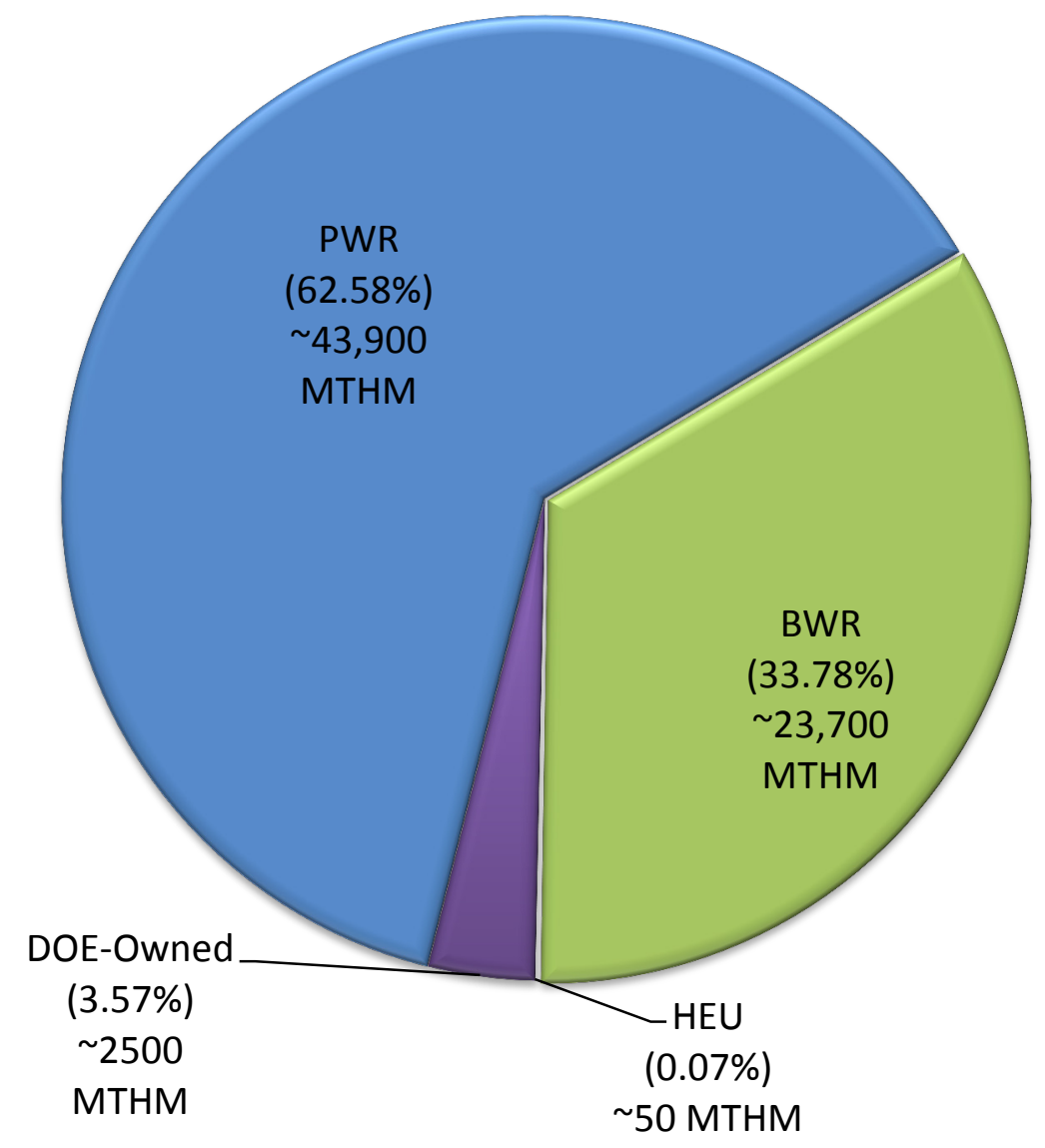

Figure 1. Mass of UNF inventory constituents as of 2011 (HEU portion too small to be visible). Source: Ref. 3.

\subsection{COMMERCIAL USED NUCLEAR FUEL}

Approximately 67,600 MTHM of commercial UNF, representing a total of $\sim 23$ billion curies of longlived radioactivity, ${ }^{3}$ are currently stored at 75 sites in 33 states. ${ }^{4}$ The commercial UNF inventory is currently increasing annually by $\sim 2,000 \mathrm{MTHM}^{4}$ and will increase at a greater rate in the future if the number of operating nuclear reactors increases. Commercial UNF discharge data, on an assembly basis, were collected and published ${ }^{5}$ by the Energy Information Administration for the Office of Civilian 
Radioactive Waste Management through 2002. Although limited to discharges through 2002, these data represent the most detailed available information on the commercially discharged UNF inventory. More recently, data have been assembled from a variety of sources by the DOE-NE Used Fuel Disposition Campaign (UFDC) to develop an inventory estimate through $2011 .^{3}$ Data from both of these sources were used in this assessment.

Commercial nuclear power plants have been operating in the United States since 1957, ${ }^{*}$ and there are currently 104 operating nuclear power plants. Used nuclear fuel from these plants is stored on-site in spent fuel pools and in dry storage casks, complicating the cost and issues associated with UNF management. Dry storage facilities, referred to as independent spent fuel storage installations (ISFSI), are in operation at the majority of reactor sites, including 10 sites in 9 states that no longer have operating reactors. Figure 2 shows the location of operating and shutdown commercial reactor sites. Commercial UNF includes irradiated fuel discharged from pressurized water reactors (PWRs) and boiling water reactors (BWRs). In 2011, 74\% of the total mass of commercial UNF was stored in spent fuel pools, and the remaining $26 \%$ was in dry cask storage. ${ }^{6}$ However, these proportions will slowly change ${ }^{6,7}$ as most spent fuel pools are at or near their capacity. The distribution of the current UNF inventory from PWRs and BWRs in wet (pool) and dry storage is illustrated in Figure 3.

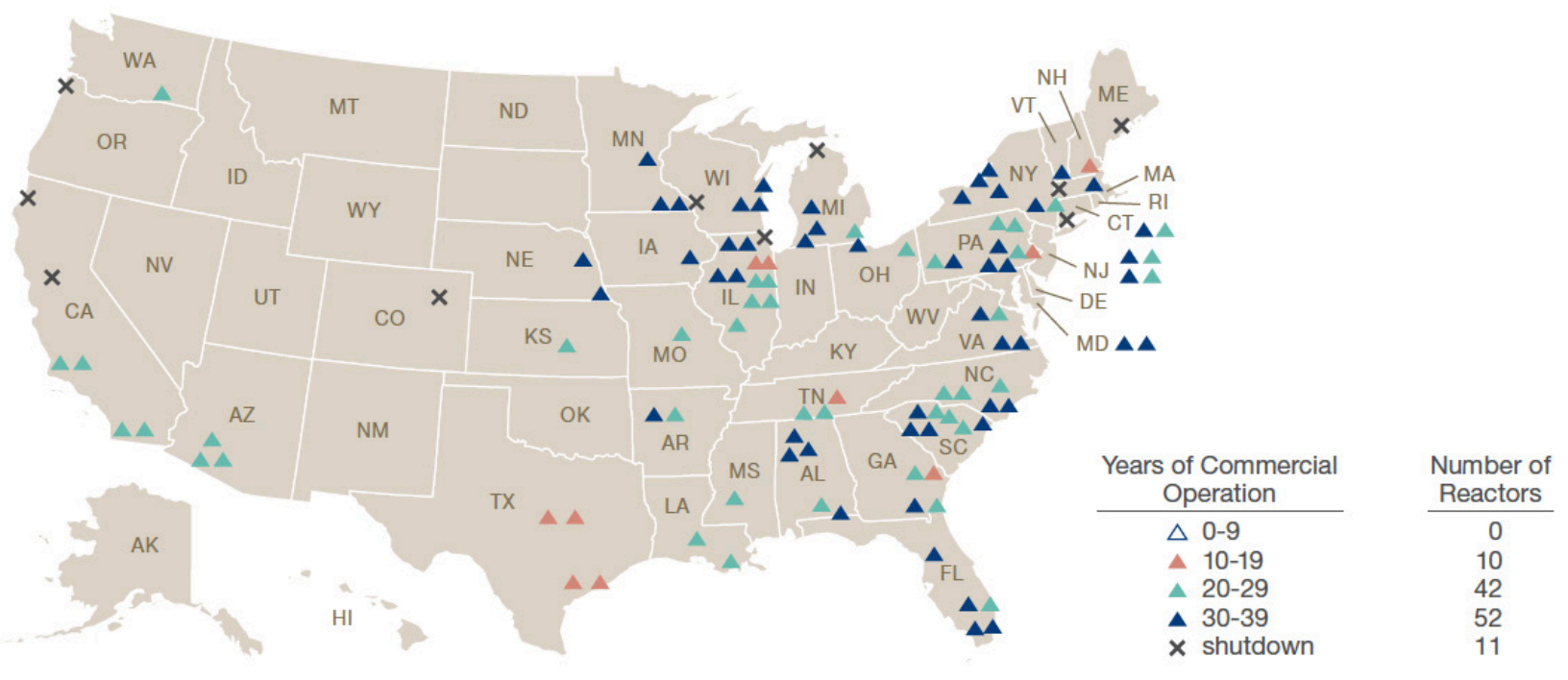

Source: U.S. Nuclear Regulatory Commission

Figure 2. Operating and shutdown commercial reactor sites.

\footnotetext{
${ }^{*}$ Note that the UNF from the first commercial nuclear power plant, the Shippingport Atomic Power Station, is now classified as DOE-owned fuel.
} 


\section{BWR $23,700 \mathrm{MTHM}$}

PWR 43,900 MTHM

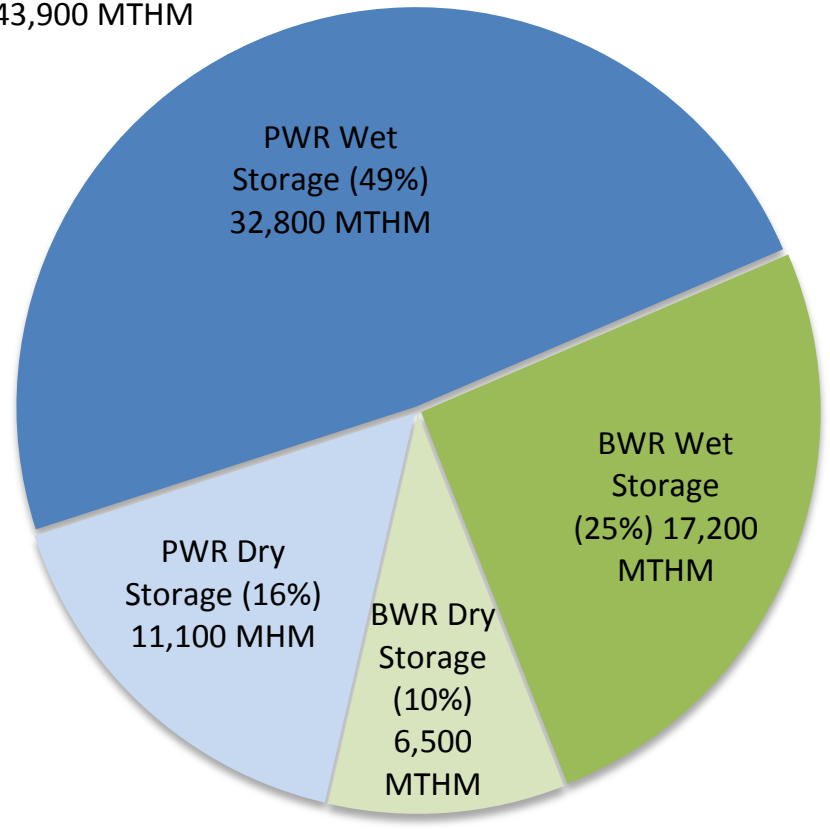

Figure 3. Distribution of current (2011) commercial UNF inventory from PWRs and BWRs in wet and dry storage (data from Refs. 3, 5, 6, and 8).

The fuel used in commercial nuclear power reactors consists of uranium dioxide pellets encased in zirconium alloy (Zircaloy) tubes for the majority of the fuel and in stainless steel tubes for a much smaller fraction. The fuel assemblies vary in physical configuration, depending on reactor type and manufacturer, and have evolved in the United States over the past several decades. BWRs have used fuel assemblies arranged in $6 \times 6,7 \times 7,8 \times 8,9 \times 9,10 \times 10$, and $11 \times 11$ arrays of fuel pins, as well as some nonsymmetric configurations and a range of lattice variations, such as water holes and part-length rods. PWRs have used fuel assemblies arranged in $14 \times 14,15 \times 15,16 \times 16$ and $17 \times 17$ arrays of fuel pins. The distributions of assembly lattice sizes and fuel vendors for the current inventory of discharged UNF are shown in Figures 4 and 5, respectively. The different reactor types and evolution in fuel assembly designs and reactor operating conditions have resulted in considerable variation in the characteristics (e.g., assembly and cladding materials, initial enrichment, discharge burnup, burnable poison types, and irradiation exposure conditions) of the current UNF inventory. The variation is evident in the fact that commercial UNF assemblies have been categorized ${ }^{5}$ by physical configuration into 22 classes: 16 PWR and 6 BWR fuel assembly classes. In Appendix A, Tables A-1 and A-2 present the assembly class, array size, fuel manufacturer, assembly version, assembly type code, length, width, and cladding material of commercial PWR UNF and commercial BWR UNF, respectively. Within an assembly class, assembly types are of a similar size. There are 137 individual fuel assembly types in these 22 classes. Table A-3 presents the number of assemblies, initial uranium load, enrichment, burnup, and cooling time characteristics of the commercial PWR and BWR UNF assembly types, respectively. Tables A-4 and A-5 provide summaries of UNF characteristics from samples, PWR fuel assemblies, and BWR fuel assemblies. The significant variation in the current inventory is illustrated in Figure 6 , which shows the distribution of the 22 assembly classes, and Figure 7 and Figure 8, which show the distribution of the fuel assembly types for PWRs and BWRs, respectively. Although Figure 7 and Figure 8 are somewhat difficult to decipher, they 
illustrate the extent of the variation in assembly types within the domestic commercial discharged UNF inventory. These variations raise issues with aspects of commercial UNF management (e.g., demonstrating compliance with storage, transportation, and disposal regulatory criteria for all the variations present in the current UNF inventory) and the viability of recycling (e.g., designing and operating a recycling facility and associated processes that can accommodate such wide variations in feedstock).

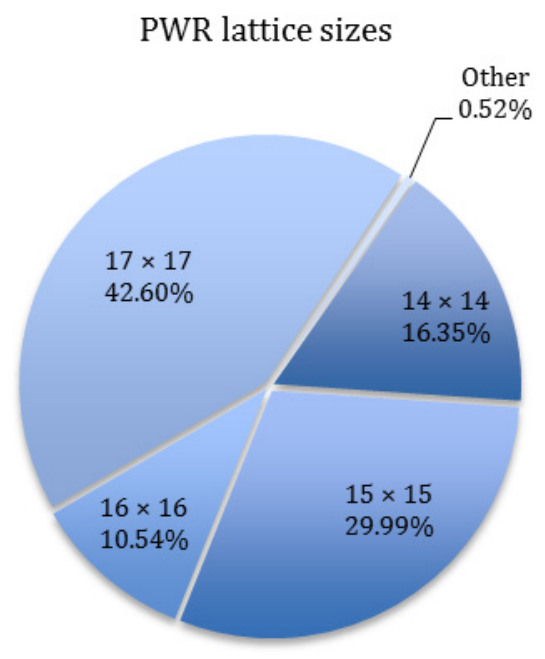

BWR lattice sizes

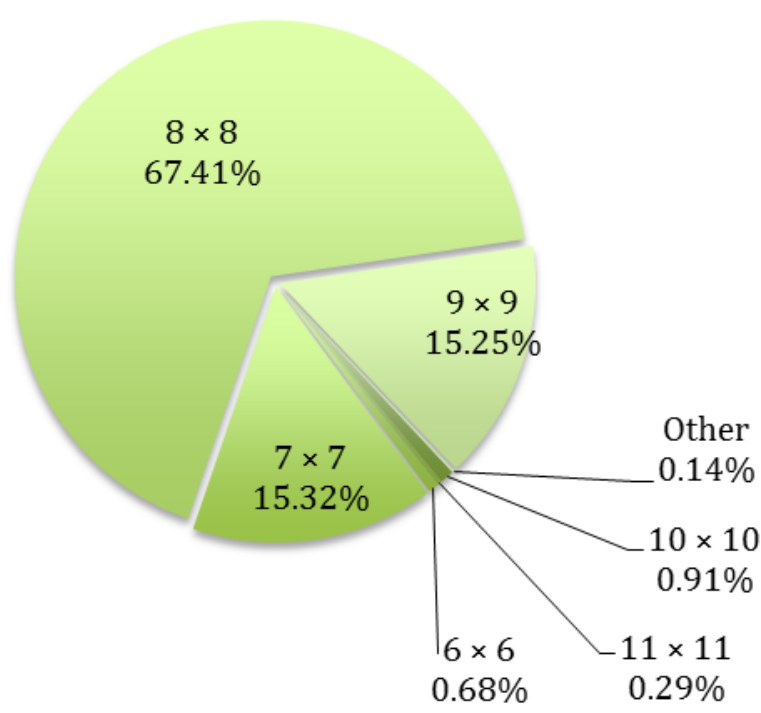

Figure 4. Distribution (through 2002) of assembly lattice sizes by mass (units are percentage of total MTHM) in the commercial UNF inventory. Source: Ref. 5.
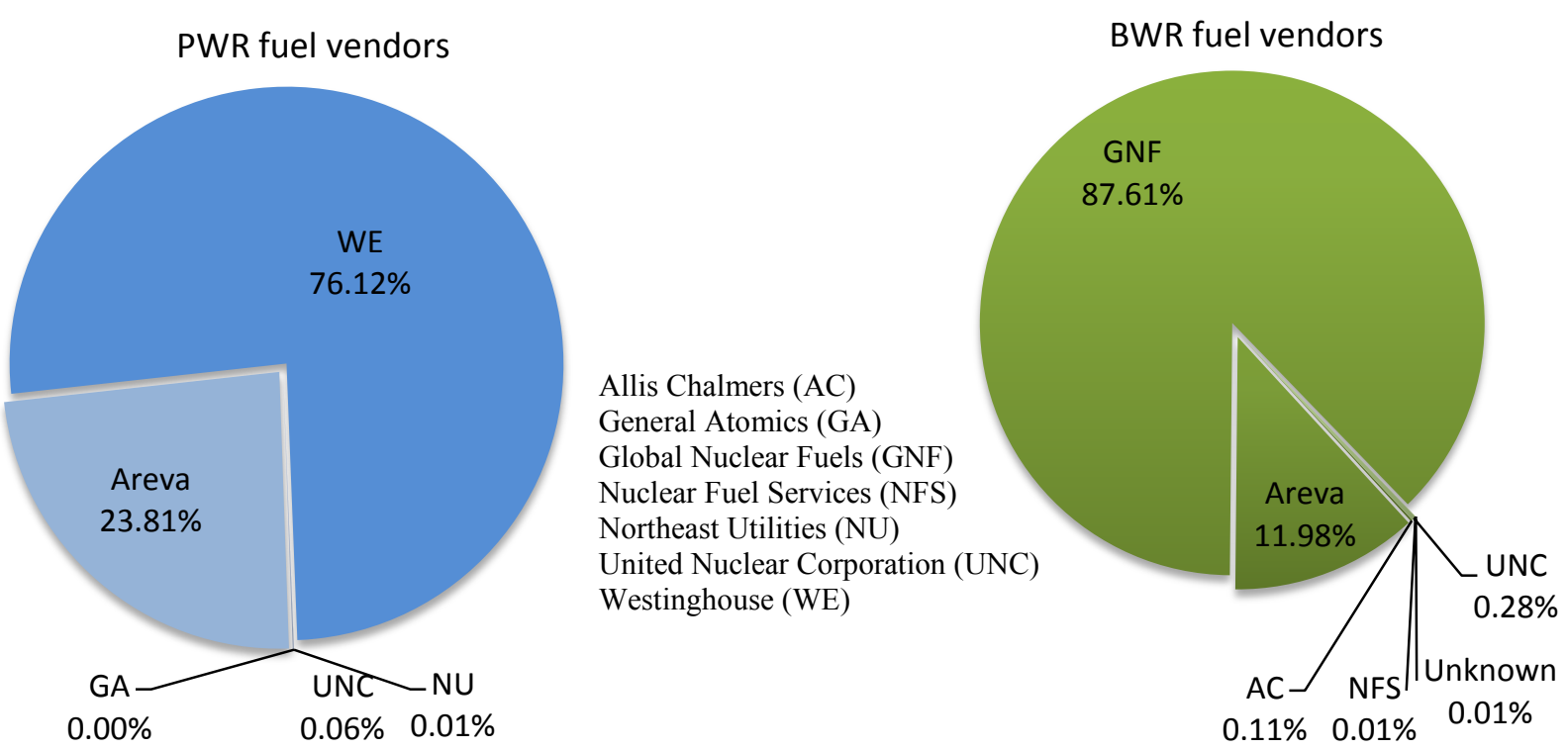

Figure 5. Distribution (through 2002) of fuel vendors by mass (units are percentage of total MTHM) in the commercial UNF inventory. Source: Ref. 5. 


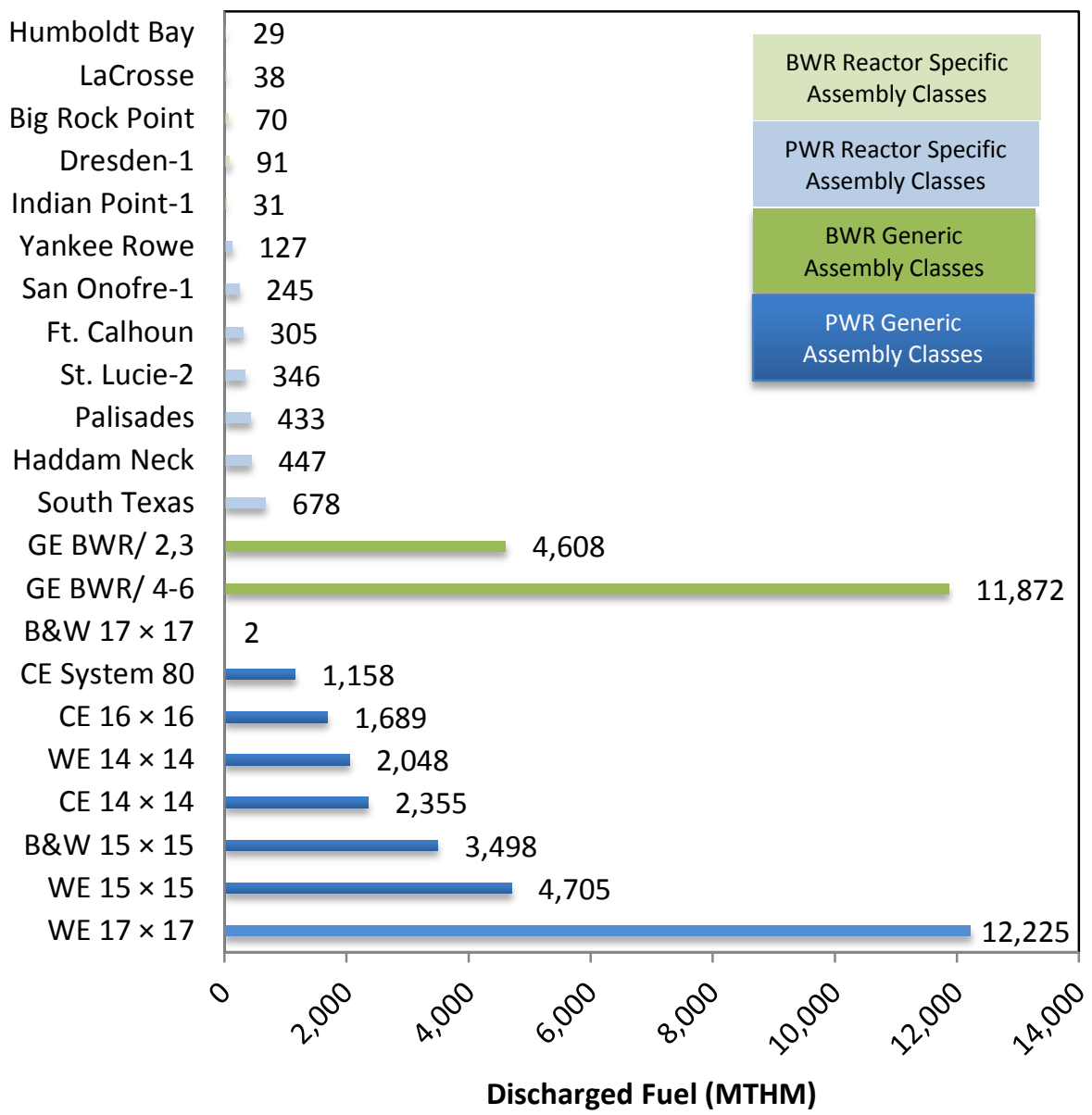

Figure 6. Distribution of assembly classes by total mass in the commercial UNF inventory as of 2002. Source: Ref. 5. 


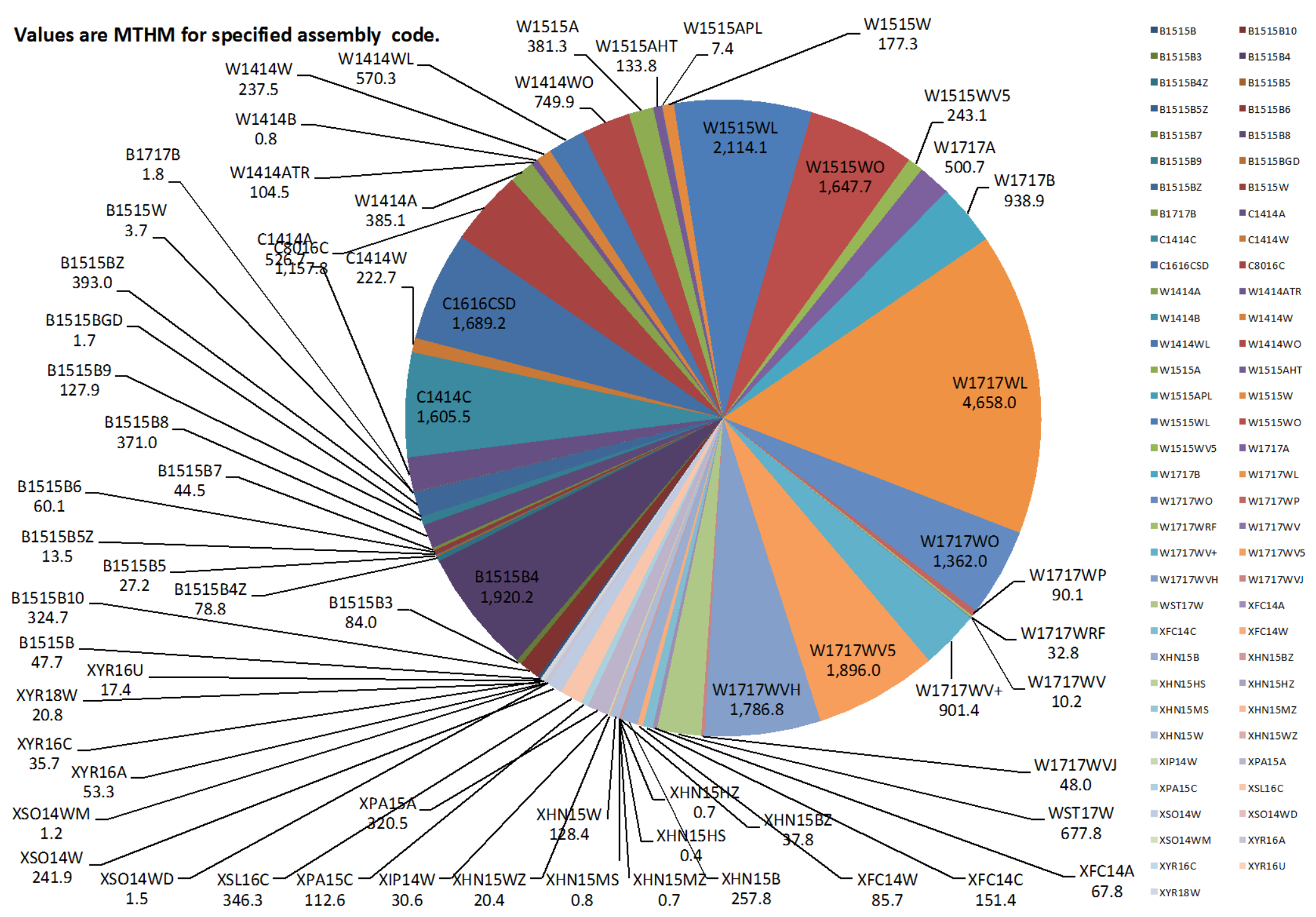

Figure 7. Distribution of PWR fuel assembly types by mass (units of MTHM) in the commercial UNF inventory as of 2002. $\underline{\text { Source: }}$ Ref. 5. 


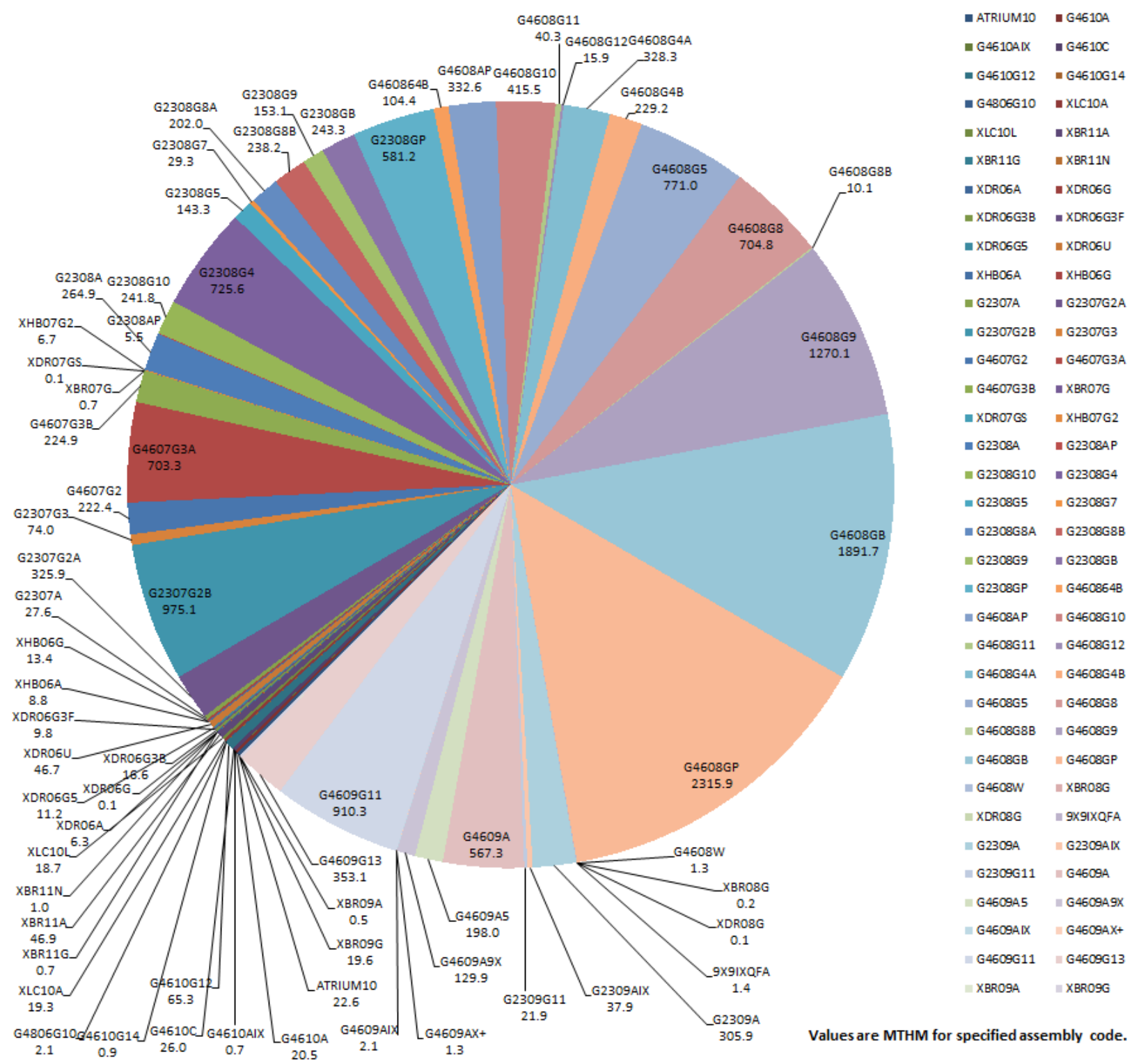

Figure 8. Distribution of BWR fuel assembly types by mass (units of MTHM) in the commercial UNF inventory as of 2002. Source: Ref. 5.

The significant variation in the discharged UNF inventory reflects the evolution of nuclear reactor and fuel assembly designs during the first $\sim 50$ years of nuclear power operation. Examination of discharges in recent years indicates that the variability in discharged fuel assemblies has decreased with time. For example, Figure 9 shows how assembly-average enrichment has increased across the U.S. commercial reactor fleet and is approaching the current limit of $5 \mathrm{wt} \%{ }^{235} \mathrm{U}$, and Figure 10 shows how burnup values have been increasing and will ultimately be limited by the limit on initial fuel enrichments. ${ }^{*}$ Figures 11 and 12 plot PWR and BWR, respectively, assembly class discharges as a function of time and show

${ }^{*}$ Note that if the current commercial reactor-licensing limit of $5.0 \mathrm{wt} \%{ }^{235} \mathrm{U}$ on fuel enrichment was increased in the future, fuel design variations would be implemented to utilize higher enrichments and discharge burnup values would increase. 


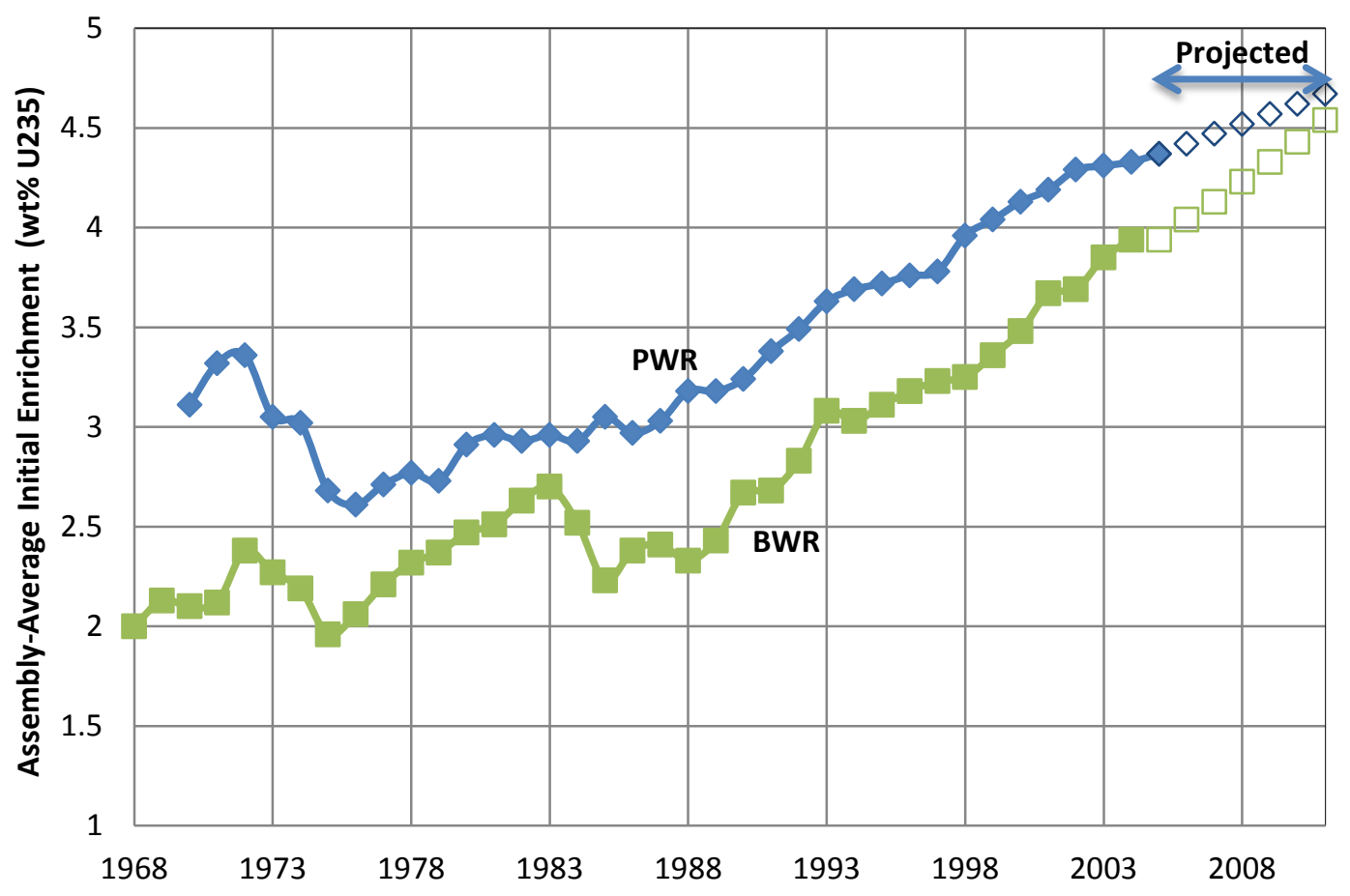

Figure 9. Assembly-average initial enrichment as a function of time. Source: Ref. 3.

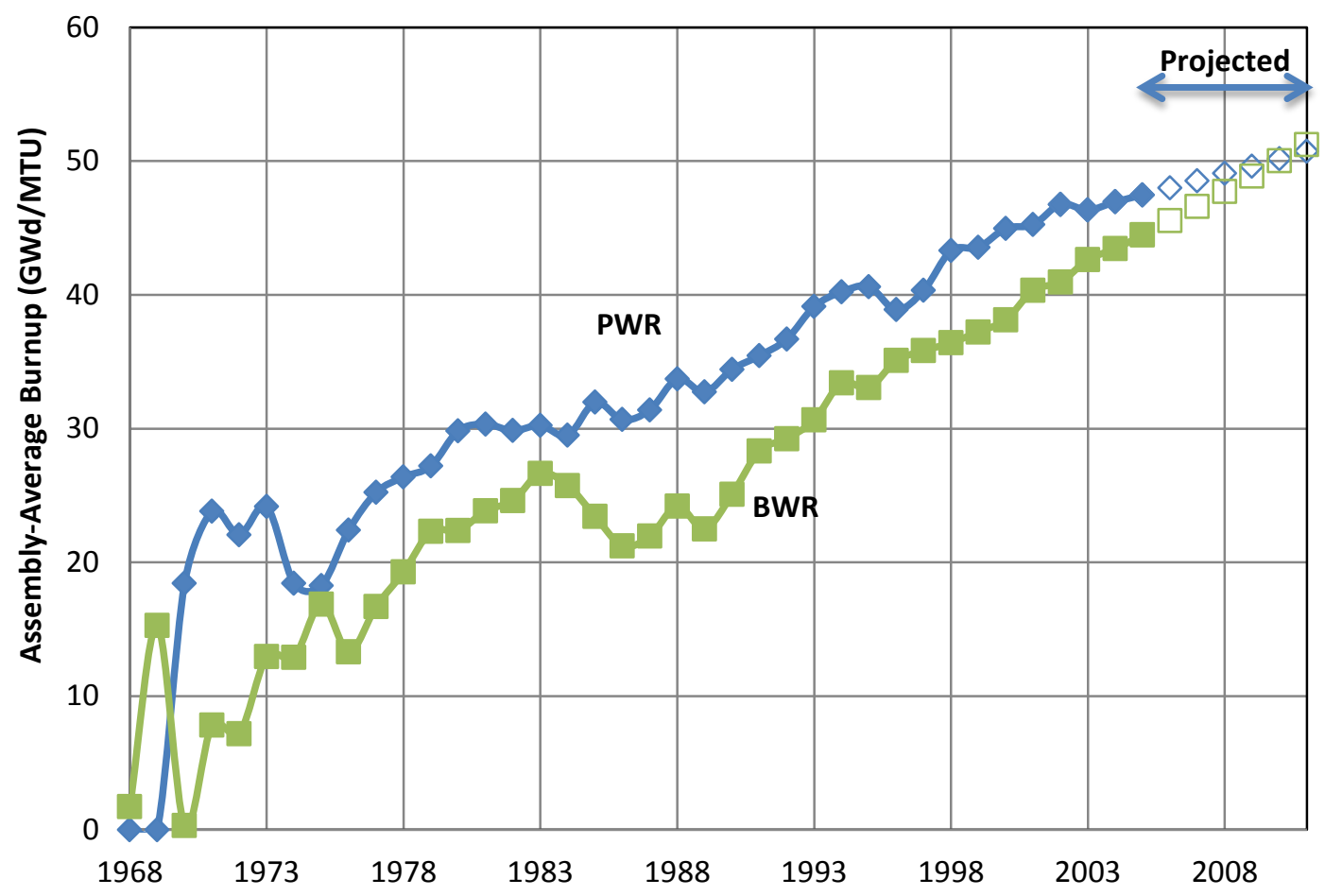

Figure 10. Assembly-average discharge burnup as a function of time. Source: Ref. 3. 


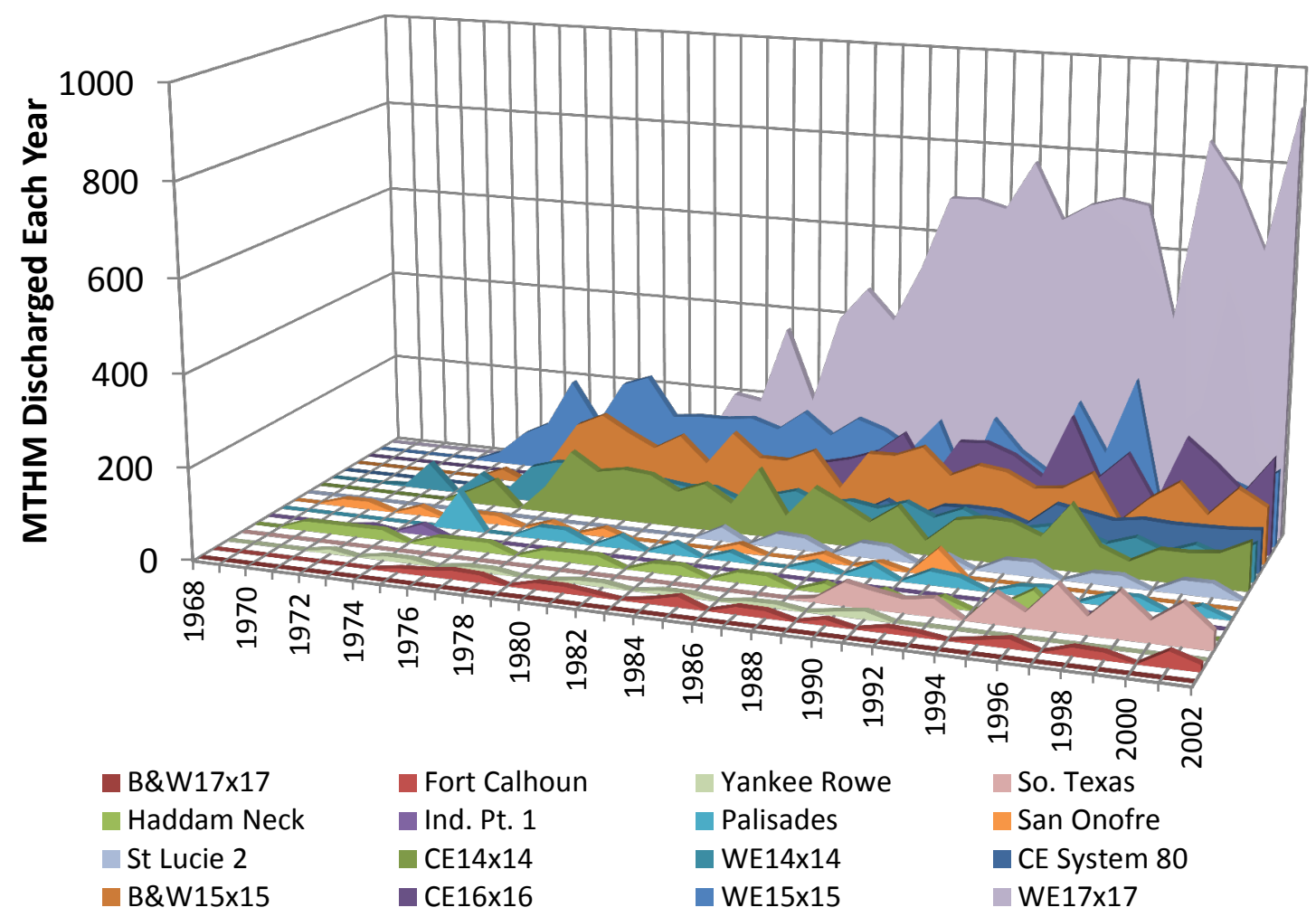

Figure 11. PWR assembly class discharges as a function of time through 2002. Source: Ref. 5.

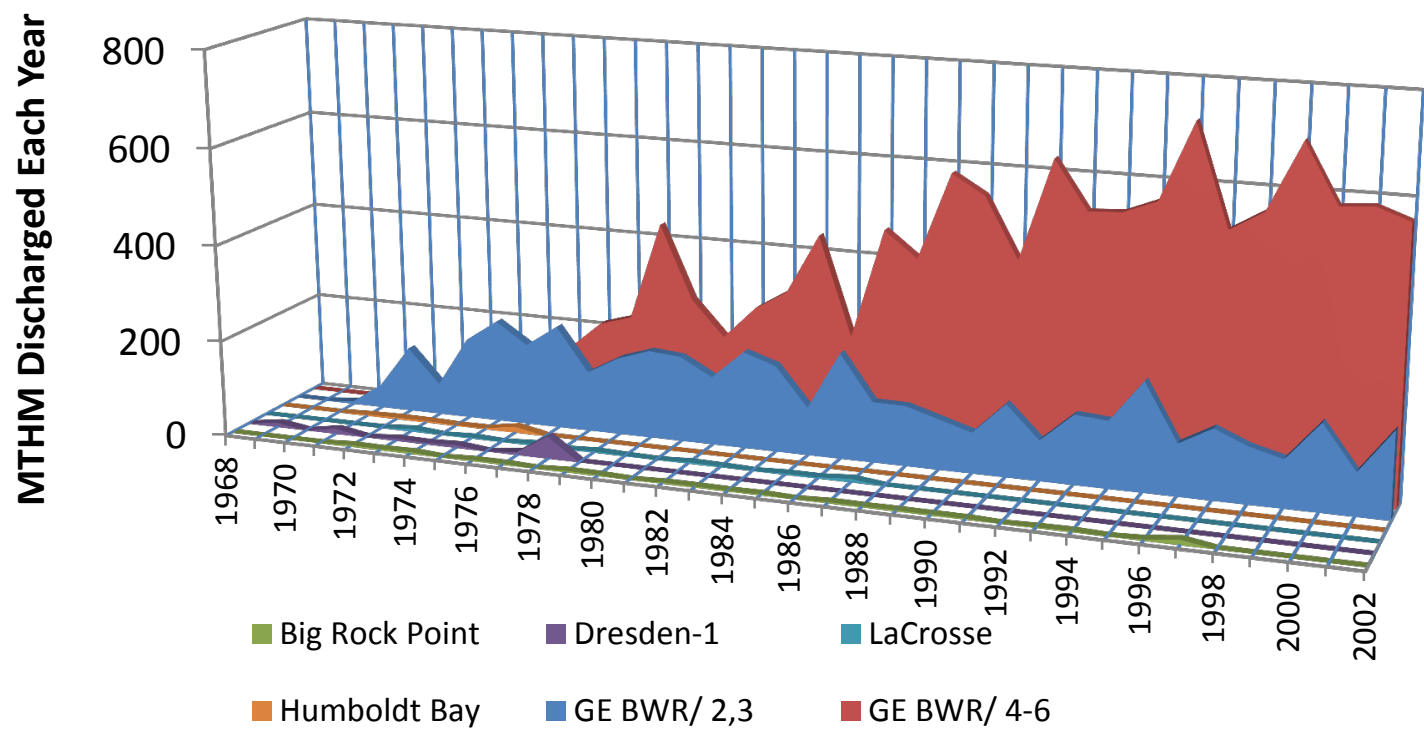

Figure 12. BWR assembly class discharges as a function of time through 2002. Source: Ref. 5. 
how the variation in assembly classes is decreasing as a number of fuel types, particularly reactor-specific fuel types, have been discontinued. Looking forward, less variation in fuel assembly designs is expected as designs have approached the current limit of $5 \mathrm{wt} \%{ }^{235} \mathrm{U}$ for initial enrichment, discharge burnup values are more uniform as they approach their upper limits, and many of the reactor-specific assembly designs are no longer being used. Also, a review of new PWR reactor designs for which combined (construct and operate) license (COL) applications have been submitted, ${ }^{9}$ that is, AP1000, U.S. EPR, and U.S. APWR, indicates that all of these reactor designs will use fuel with the same assembly lattice size (i.e., $17 \times 17$ ). This provides further support for the expectation that UNF discharges in future decades will likely have more uniform characteristics than past or current UNF discharges.

In summary, the current (as of 2011) inventory of domestic commercial UNF is massive ( 67,600 MTHM), diverse (22 unique assembly classes with varying physical characteristics and dimensions), dispersed (stored at 75 sites in 33 states in a variety of wet and dry storage systems), increasing (increasing by $2000 \mathrm{MTHM} / \mathrm{y}$ ), and evolving (reactor-specific assembly designs being phased out, initial enrichment and discharge burnup values becoming more uniform). The diversity of UNF types, characteristics, storage locations, and storage conditions of the current UNF inventory presents a variety of challenges to the safety, security, and cost of UNF management, including disposition options.

\subsection{DOE USED NUCLEAR FUEL}

Over the past half-century, since the inception of nuclear reactors, the DOE and its predecessor agencies operated or sponsored a variety of research, test, training, and other experimental reactors with different characteristics from the commercial power reactors of today. There are currently several hundred distinct types of DOE-owned UNF totaling $2500 \mathrm{MTHM}$, originating from a wide range of reactor types (such as light- and heavy-water-moderated reactors, graphite-moderated reactors, and liquid-metal-cooled fast reactors), with various cladding materials (i.e., aluminum, zirconium, stainless steel) and enrichments (varying from depleted uranium to over $93 \mathrm{wt} \%$ enriched ${ }^{235} \mathrm{U}$ ). Many of these reactors, now decommissioned, had unique design features, such as core configuration, fuel element and assembly geometry, moderator and coolant materials, operational characteristics, and neutron spatial and spectral properties. In addition, there is a relatively large number (over 200,000) of fuel pieces or assemblies, which range from a large number of pieces for some reactors (N-Reactor, 2100 MTHM) to a few individual pieces for other unique reactors (e.g., Chicago Pile-5 converter cylinders).

DOE-owned UNF generated in production reactors supported weapons and other isotope production programs. An example of UNF from production reactors is the N-reactor UNF stored at the Hanford, Washington site. Some UNF from commercial power reactors (such as Shippingport, Peach Bottom, Fort St. Vrain, Turkey Point, and Surry) is also stored within the DOE complex. This UNF was generated for commercial power demonstration purposes or obtained as part of research projects. In addition, the Three Mile Island Unit 2 UNF debris is stored at the Idaho National Laboratory (INL) and commercial UNF obtained for research purposes is stored in different locations across the DOE national laboratory complex. DOE has also sponsored nuclear research activities overseas. Research reactor UNF is being returned to the United States from foreign research reactors as part of the DOE Foreign Research Reactor Spent Nuclear Fuel Acceptance Program. ${ }^{10}$

Recent data on the DOE-owned UNF were collected and published by the DOE-NE UFDC. ${ }^{3}$ The majority of the DOE-owned UNF ( 2500 MTHM) is already in storage, with around 2100 MTHM contained in about 400 sealed canisters. ${ }^{3}$ The only new DOE-owned UNF comes from the operation of several research reactors, from university research reactors, and from the Foreign Research Reactor Spent Nuclear Fuel Acceptance Program. The predicted DOE-owned UNF inventory to be discharged from these three sources is relatively small (about 50 MTHM). ${ }^{3}$ 
To support analyses, the DOE-owned UNF inventory has been divided into 34 DOE UNF groups based on fuel matrix, cladding, cladding condition, and enrichment. A discussion of each of the 34 groupings is presented elsewhere, ${ }^{3}$ and Table B-1 in Appendix B describes the typical ranges of the nominal properties for DOE UNF in the 34 groups.

\subsection{HIGHLY ENRICHED URANIUM USED NUCLEAR FUEL}

Highly enriched uranium UNF has been generated from a variety of reactors supporting research and defense programs,. Approximately 50 MTHM of HEU UNF currently exists with an enrichment greater than $90 \mathrm{wt} \%{ }^{235} \mathrm{U} .{ }^{3,11}$ Due to the high uranium enrichment, very small amounts of transuranic isotopes are present in the HEU UNF, as compared to commercial UNF. 



\section{ASSESSMENT OF USED NUCLEAR FUEL RELATIVE TO RETENTION NEEDS}

Execution of the DOE-NE's Office of FCT mission to "develop used nuclear fuel management strategies and technologies to support meeting federal government responsibility to manage and dispose of the nation's commercial used nuclear fuel and high-level waste; develop sustainable fuel cycle technologies and options that improve resource utilization and energy generation, and reduce waste generation, enhance safety, and limit proliferation risk" requires immediate and continued access to select UNF material to support the following program objectives. ${ }^{1}$

- Develop a strengthened technical and scientific basis for extended UNF storage.

- Select preferred sustainable fuel cycle options for further development.

- Conduct science-based, engineering-driven research for selected sustainable fuel cycle options.

- Develop the scientific basis for multiple disposal options for UNF and high-level waste.

- Have implemented acceptable and safe options, strategies, and solutions for management (including extended storage and long-term disposal) of UNF and nuclear waste.

- Test and make available advanced technologies that enable sustainable fuel cycles.

All of these program objectives pertain to either UNF management or alternative fuel cycles, and hence the potential needs for access to UNF material are discussed in terms of those two categories in this section.

\subsection{TENETS AND ASSUMPTIONS}

The following tenets and assumptions were used in this assessment.

\subsubsection{Tenets}

1. Access to some amount of UNF is needed to support RD\&D for the DOE-NE FCT program objectives related to UNF management and alternative fuel cycles.

2. The two principal options for addressing UNF management are geologic disposal and recycling.

\subsubsection{Assumptions}

1. U.S. nuclear power plants will continue to discharge 2000 MTHM annually for the next couple of decades; projections beyond the next couple of decades are less certain. Annual discharge mass can be expected to decrease slightly with increasing discharge burnup values (i.e., greater energy produced per assembly). The discharge rate is most sensitive to the number of operating nuclear power plants, that is, an increase (decrease) in nuclear power utilization in the United States will increase (decrease) the annual discharge rate.

2. The option of recycling commercial UNF at a future date is maintained, pending a decision.

3. Although fuel recycling depends on future decisions, it is assumed that industrial-scale (100s to 1000 s of MTHM/y) recycling of commercial UNF is unlikely to begin for at least 20 years (2030 time frame), at which time an additional 40,000 MTHM of UNF will have been discharged.

4. Recycling in any potential future alternative fuel cycle would likely be designed and optimized for the material needs of the associated reactor fleet based on the current and projected UNF discharges and inventory at that time, rather than UNF feedstock that is no longer being 
produced. Since current trends indicate that future UNF will have more uniformity and high-burnup values relative to the majority of discharged UNF in the current inventory, it is assumed in the current evaluation that any potential future recycling facilities would be designed and optimized for those "standard" conditions rather than having the capability to process potentially significantly different legacy UNF. It is, however, assumed that access to a representative sample of the current inventory should be maintained for RD\&D purposes, to ensure that they can be stored for an extended period, handled safely during transportation, and be safely disposed of in a repository.

5. The time frame for the development of alternative fuel cycles is assumed to be consistent with the schedule in the DOE-NE R\&D Roadmap. Based on this assumption, reasonable projections for electricity growth, share of nuclear electricity, and the current and historical rate of deployment of new and unproven (at the industrial scale) nuclear technologies in the regulated nuclear industry, the current and projected future inventory of commercial discharged UNF is determined to exceed the material needs for any realistically conceivable future alternative fuel cycles. In other words, the material needs of future advanced reactors can be met without reliance on the current UNF inventory. It is recognized that this determination may not be valid under some scenarios that involve rapid deployment of numerous advanced reactors; however, such a rapid development is not consistent with the schedule in the DOE-NE R\&D Roadmap.

6. It is assumed that the transportation and placement of the current UNF inventory in disposal is unlikely to begin for at least 10 years and will take several decades. ${ }^{6}$ Hence, it is assumed that even if the nation were to proceed with disposal immediately, a large fraction of the UNF inventory will be accessible for several decades.

\subsection{USED NUCLEAR FUEL MANAGEMENT}

\subsubsection{Used Nuclear Fuel Material Need}

The domestic UNF inventory has been and continues to be managed safely. Maintaining a strong technical basis for safe and secure storage, transportation, and disposal of UNF is essential for the sustainability of nuclear power generation in the United States. At present, the long-term nuclear waste management strategy for the United States is uncertain, but the DOE is responsible for the ultimate disposition of the UNF. The DOE-NE FCT established the UFDC to provide technical support for this responsibility. The UFDC is chartered to identify alternatives and conduct scientific research and technology development to effectively manage (i.e., store, transportation, and dispose) UNF and waste generated by existing and alternative nuclear fuel cycles. In support of this charter, the UFDC completed a technical gap analysis for extended storage ${ }^{12}$ in January 2012 and for transportation ${ }^{13}$ in August 2011. Both efforts, as well as similar efforts by the Nuclear Regulatory Commission (NRC), ${ }^{14}$ the Electric Power Research Institute (EPRI), ${ }^{15}$ and the Nuclear Waste Technical Review Board (NWTRB), ${ }^{16}$ identified data and modeling needs and proposed RD\&D activities for each gap. Although the details have yet to be finalized, RD\&D plans are being developed to support closure of these technical gaps and access to a representative sample, as well as sufficient quantities to enable reliable statistical analyses, of the diverse commercial UNF inventory is an identified need to support phenomenological/separate effects, small-scale, and full-scale demonstration testing. ${ }^{17}$ Therefore, it is considered prudent to retain access to a sufficient quantity of representative samples of commercial UNF to support planned RD\&D efforts and to be available to support addressing questions and issues that may arise in the future. Although the focus of this report is on UNF, it is noted that RD\&D needs to support storage, transportation, disposal, and potential recycling of non-fuel components, such as rod control cluster assemblies (RCCAs), axial power shaping rod assemblies (APSRAs), burnable poison rod assemblies (BPRAs), and control blades. Such components should also be considered and addressed. 


\subsubsection{Selection Criteria for Used Nuclear Fuel}

As discussed in Section 2.1, the current U.S. commercial UNF inventory includes a wide variety of fuel assembly designs by several reactor vendors that have experienced varying reactor operating and storage histories. Given that there is a recognized need to maintain access to a sufficient quantity of representative samples of commercial UNF to support UNF management, the next step is to determine the important characteristics of those representative samples and estimate the needed quantities to support identification of material for retention. With this objective in mind, a review of the U.S. UNF inventory and previous similar efforts ${ }^{18}$ was performed with the intent of identifying criteria for selecting representative samples and sufficient quantities for retention of access. Some of the selection criteria are focused on specific issues such as understanding and predicting clad integrity and those affecting fuel assembly long-term structural integrity, while others are focused on ensuring access is maintained to UNF representing the full range of parameters characterizing the UNF inventory to support resolution of potential future issues. At this point, it was decided to err on the side of inclusion, such that future refinements of the selection criteria might reduce the variety and amount of material for which access is retained. Furthermore, at this stage, no attempt has been made to identify individual fuel assemblies for retention. The following sections describe the selection criteria used in this assessment, which can be grouped into the following two main categories: (1) assembly design and (2) assembly exposure and operating history.

\subsubsection{Assembly Design (Lattice and Materials)}

Commercial nuclear power plants have been generating UNF since the first commercial nuclear power plant began operation in 1957. As of the end of 2011, an estimated 234,000 fuel assemblies containing 67,600 MTHM were identified as discharged. ${ }^{3}$ BWRs have used fuel assemblies arranged in $6 \times 6,7 \times 7$, $8 \times 8,9 \times 9,10 \times 10$ and $11 \times 11$ arrays of fuel pins. PWRs have used fuel assemblies arranged in $14 \times 14$, $15 \times 15,16 \times 16$ and $17 \times 17$ arrays of fuel pins. There have been many variations within each assembly array (or lattice) size such that Ref. 5 identified 137 distinct BWR and PWR fuel assembly types. Since 2002, additional fuel types have been introduced. Design variations include fuel pellet diameter variations, number, size, and placement of water rods in BWR assemblies, fuel rod clad material, fuel guide tube material, grid strap material, and many other variations. There have also been relevant variations within many of the fuel assembly types. For example, the use of integral or "built-in" burnable absorbers, such as $\mathrm{Gd}_{2} \mathrm{O}_{3}$ mixed in the fuel pellet and $\mathrm{ZrB}_{2}$ coated on the surface of fuel pellets, may affect the long-term properties of the fuel material.

Because many of the aforementioned design variations are directly relevant to the performance of the UNF assemblies during extended storage, transportation, and disposal, one of the more important selection criteria is to retain representative samples and sufficient quantities of each major lattice manufactured by each of the vendors, including variations in fuel rod clad, grid, and assembly hardware materials used. Consideration should be given to including UNF with the various integral fuel burnable absorbers and with axial blankets. Although the various UNF storage, transportation, and disposal RD\&D plans are not yet completed, it is expected that much of the needed RD\&D can be performed on representative fuel rods, as opposed to full fuel assemblies.

\subsubsection{Assembly Exposure and Operating History}

Assembly Burnup. As all phenomena relevant to UNF storage, transportation, and disposal are directly or indirectly related to fuel burnup, fuel samples should be selected to cover the full range of burnup values. Of particular interest are assemblies with high burnup, as concerns have been raised relative to cladding integrity of high-burnup fuel. ${ }^{19}$ Such assemblies have received the highest integrated radiation doses and thermal stresses, and may have cladding walls with reduced thickness from in-reactor 
formation of oxides or zirconium hydride. Assemblies representing the full range of assembly burnup values are also of interest to support development of burnup-dependent models for fuel degradation mechanisms and validation of a variety of computational predictions.

Figure 13 shows the distribution of assembly average burnup values as of the end of 2002, and Figure 10 shows how assembly average discharge burnup values have increased with time. It is recommended that access be retained to fuel assemblies with burnup values throughout the range of 10 to $60 \mathrm{GWd} / \mathrm{MTU}$.

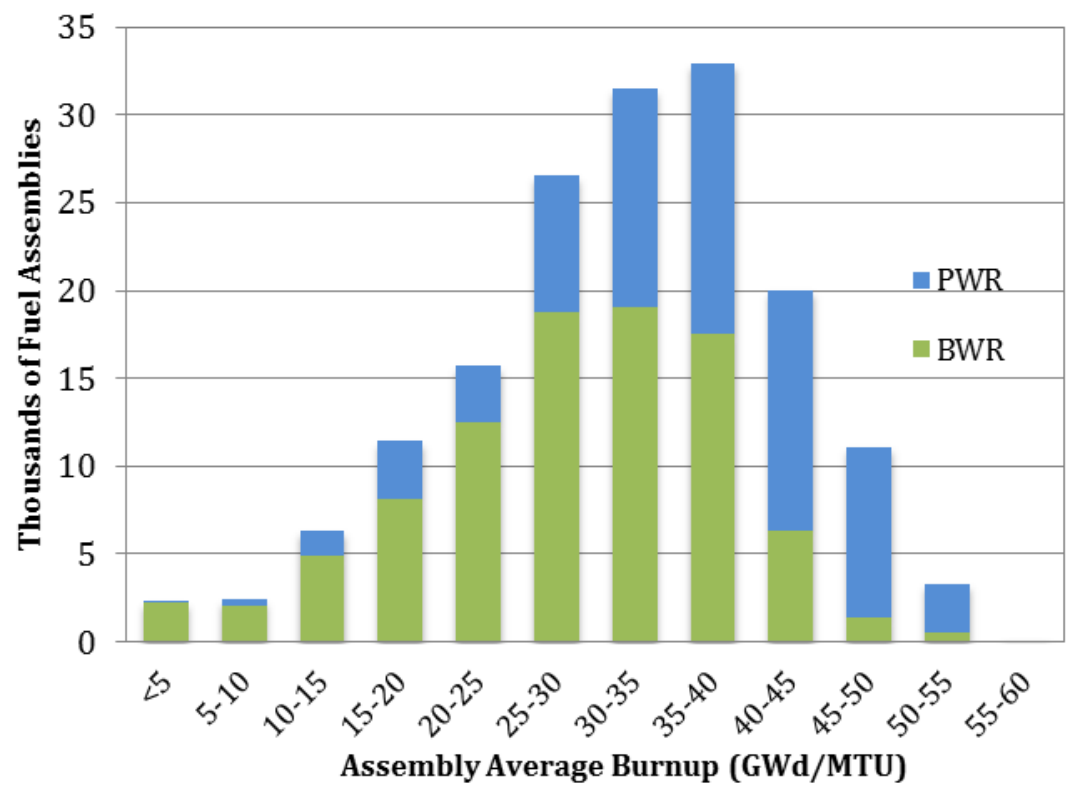

Figure 13. Distribution of assembly average burnup for all PWR and BWR fuel assemblies discharged through 2002. Source: Ref. 5.

Cooling time (time after discharge from the reactor). Some of the UNF currently in the commercial inventory has been stored for more than 40 years, and a portion $(\sim 10 \%)$ has been stored for 30 years or more. To the extent practicable, UNF with cooling times out to 40 years should be included in the UNF retained for future study. The availability of a continuum of cooling times could support studies of UNF aging. Figure 14 provides a characterization of the cooling time experienced by UNF as of 2011. From this figure, $\sim 16 \%$ of the UNF was discharged less than 5 years ago. 


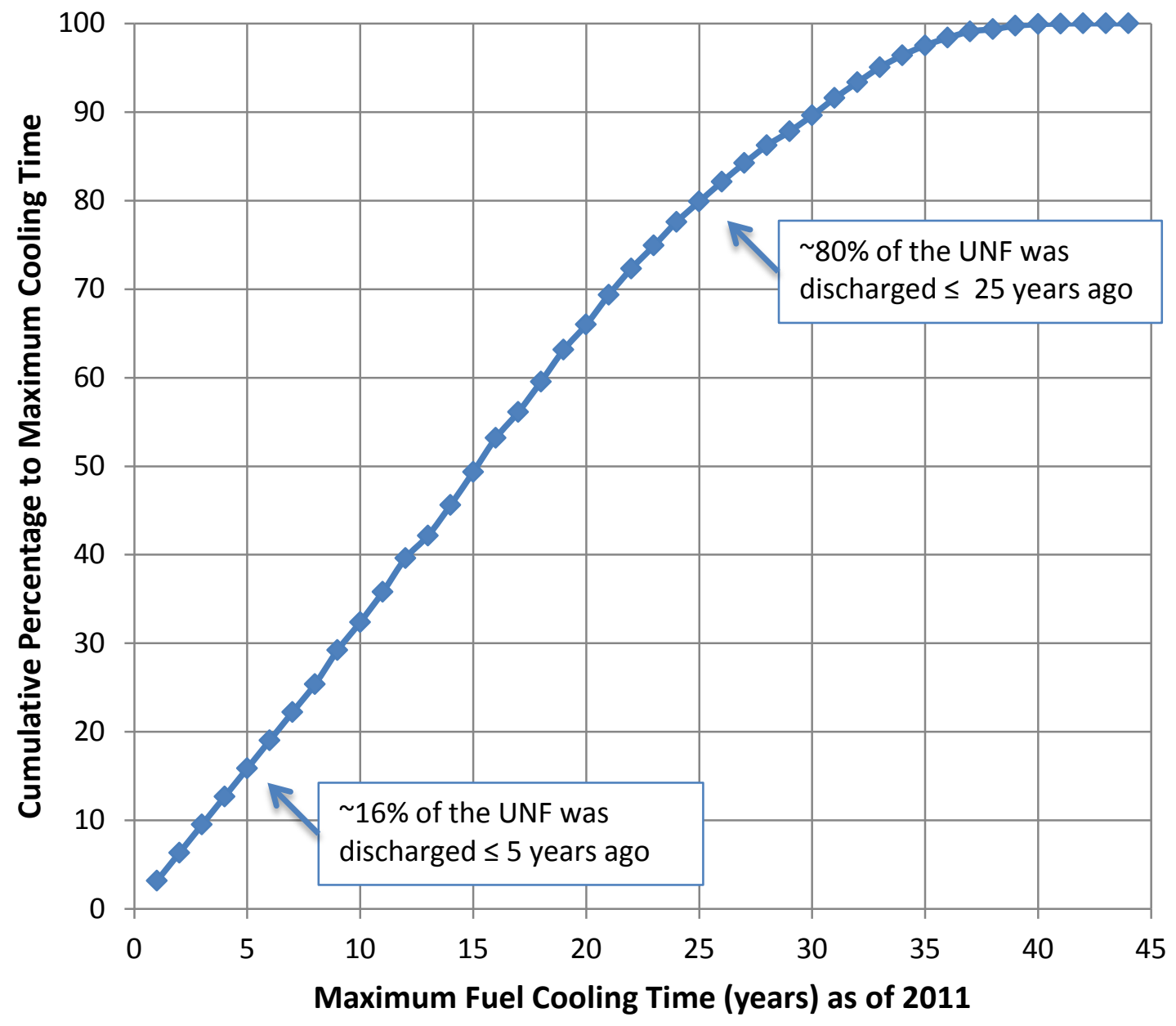

Figure 14. Post-irradiation cooling time as of 2011 (data through 2002 from Ref. 5; annual discharge of 2000 MTHM assumed after 2002).

Reactor Environment. The conditions under which the fuel is used vary from reactor to reactor and cycle to cycle and can directly impact fuel performance during and following irradiation. Selection of UNF should include consideration of the variation in coolant chemistry, shutdown periods between operating cycles, exposure to removable absorbers such as RCCAs, APSRAs and BPRAs, and the reactor average power density.

Post-Irradiation Storage Environment. As of 2011, 26\% (by mass) of UNF has been placed in dry cask storage. ${ }^{6}$ The remainder $(\sim 74 \%)$ is stored (wet) in spent fuel pools. Some of the dry storage casks were loaded more than 15 years ago (Figure 15). Retained UNF should include samples of UNF that have been in dry and wet storage conditions for varying amounts of time to support study of the impacts of long-term storage, including investigations of cladding integrity and assembly material corrosion. 


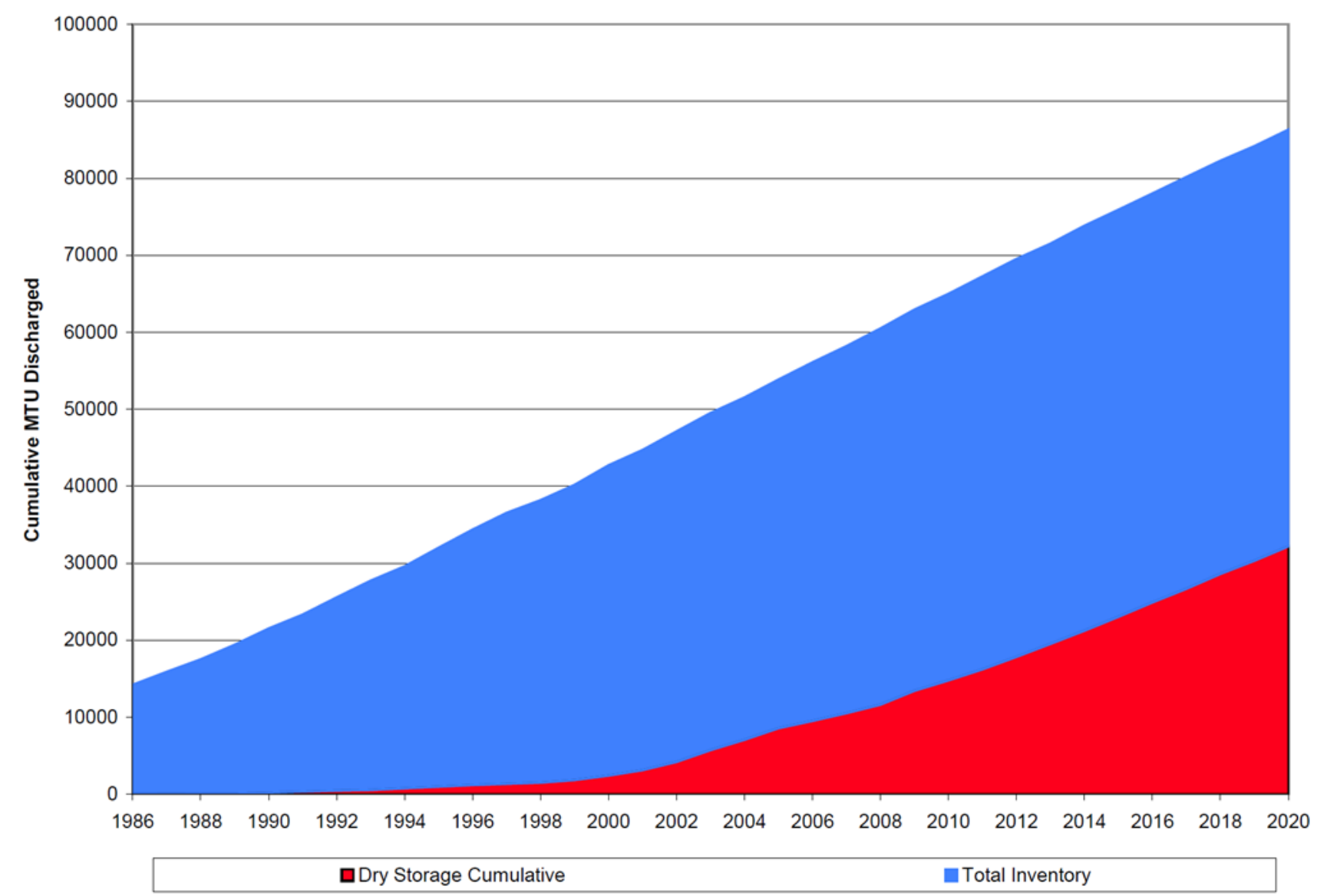

Figure 15. Historical and projected discharges of commercial used nuclear fuel. Source: Ref. 7.

For UNF that is currently in dry storage, a variety of dry storage cask systems have been used throughout the U.S. Selection of UNF for retention of access could include consideration of cask designs used and the environment in which the cask systems have been used. Factors considered might include above ground versus below ground storage and local climate variation, such as exposure to marine environments. Retention of a variety of cask designs would prove useful for studying the long-term integrity of various dry storage systems, including canister integrity, and is consistent with proposed fullscale demonstration testing to support industry-wide aging management plans. For UNF that is currently in wet storage, selection of UNF for retained access should consider variation in the spent fuel pool environment, such as water chemistry. 
Post-Irradiation Assembly Condition. Selection of UNF for retention could include consideration of the post-irradiation assembly condition. Some assemblies exhibit assembly twist or bow after they are removed from the reactor. These conditions may indicate unusual stresses in the assembly structures. Such assemblies may be useful in the study of the long-term structural integrity of UNF. Additionally, some PWR assemblies are used in ways that result in significant cross-assembly burnup gradients. Such gradients may also indicate cross-assembly stresses in the grids that hold the assembly together.

Damaged or Reconstituted Fuel. A small fraction, 0.012 by mass through $2002,{ }^{5}$ of the UNF has been identified as damaged and has been either repaired or segregated. Inclusion of samples of such fuel would support research into fuel damage mechanisms.

Consolidated Fuel. A small fraction, 1.32 E- 5 by mass through $2002,{ }^{5}$ of the UNF has been disassembled and the removed fuel rods placed into consolidated fuel canisters. ${ }^{20}$ Retained UNF should consider inclusion of consolidated fuel to support resolution of potential future issues that may arise.

\subsubsection{Summary}

Tables A-1 through A-4 provide summary information ${ }^{5}$ that describes the commercial UNF inventory. The discussion in this section and the information in Appendix A are provided to give the reader an understanding of the complexity of the process needed to select a sufficient quantity of representative commercial UNF to retain for future RD\&D efforts. With these complexities in mind, a set of selection criteria was developed and described in this section. Some of the selection criteria are focused on specific issues such as understanding and predicting clad integrity and those affecting fuel assembly long-term structural integrity, while others are focused on ensuring access is maintained to UNF representing the full range of parameters characterizing the UNF inventory to support resolution of potential future issues. At this point, it was decided to err on the side of inclusion, such that future refinements of the selection criteria might reduce the variety and amount of material for which access is retained. The selection criteria were grouped into the following two main categories: (1) assembly design and (2) assembly exposure and operating history. Recommendations for retention of UNF for future RD\&D based on the selection criteria discussed above are provided in Section 5.

\subsection{ALTERNATIVE FUEL CYCLES}

The development of sustainable fuel cycles ${ }^{*}$ is one of the four main R\&D objectives for nuclear energy in the DOE-NE Roadmap. ${ }^{2}$ Sustainable fuel cycle options are defined in the DOE-NE Roadmap as those that improve uranium resource utilization, maximize energy generation, minimize waste generation, improve safety, and limit proliferation risk. As stated in the DOE-NE Roadmap, the key challenge is to develop a suite of fuel cycle options that will enable future decision makers to make informed choices about how best to manage the UNF from reactors. The options for sustainable fuel cycles, as described in the DOE-NE Roadmap, include both once-through and recycle fuel cycles, where once-through options dispose of UNF while recycle options reprocess UNF so that some of the elements can be recovered and included in new fuel. Recycle fuel cycles dispose of high-level wastes, and may also dispose of UNF if all UNF is not reprocessed.

There are numerous technical issues to address in the development of alternative fuel cycle options and the supporting technologies, some of which can be studied using surrogate materials for UNF, and others that can only be investigated using actual UNF, such as the effects of prior irradiation, radiation, and

*Except where reference is made to specific aspects of the DOE-NE Roadmap, "alternative fuel cycles" is used in this report to refer to any and all possible future fuel cycles, including sustainable fuel cycles as they are defined in the DOE-NE Roadmap. 
decay heat. As a consequence, to support the RD\&D, there is a need to have representative UNF available to complete development and testing of candidate technologies, whether for extended storage, reprocessing, disposal, or advanced reactor fuel development.

When assessing the existing UNF inventory relative to retention needs to support alternative fuel cycles, there are two principal considerations - access to UNF to support

1. ongoing $\mathrm{R} \& \mathrm{D}$ of alternative fuel cycles, particularly those involving reprocessing and recycle, and

2. deployment of a potential future recycle fuel cycle, for which some portion of the existing inventory could have potential value that would be recovered by reprocessing.

Each of these considerations is discussed in the following subsections.

\subsubsection{Used Nuclear Fuel to Support R\&D}

Development of alternative fuel cycle options will require RD\&D in several areas, including separations technology development for processing UNF, especially for recovering certain elements from the UNF, and fuel form and reactor technology development for effectively using the recycled UNF material. As the technologies develop, it will become essential to test processing and fuel fabrication technologies with actual UNF to fully understand and address the various issues and complications that may arise when using actual UNF. For example, the radiation emitted by UNF can be substantial, being highest at discharge and decreasing steadily with time due to radioactive decay. The radiation from the UNF can have significant implications for process chemicals, shielding of facilities and equipment, and handling. Decay heat can also be an important issue, especially for processes that can accumulate heat-producing nuclides. The content of UNF, the chemical form of the elements in the UNF, and the physical form all need to be studied to ensure that the technologies will work as required. The material and the chemical and physical condition of the cladding may also influence the total amount recovered in processing, as well as the amount of material lost in the waste stream (e.g., in the form of undissolved solids) and the amount of post-processing waste.

The RD\&D for alternative fuel cycle options will require access to sufficient amounts of UNF with appropriate characteristics. In considering the relevant UNF characteristics, it is important to again recognize that light water reactor (LWR) fuel has evolved over the past several decades, with increases in initial enrichment, increases in the discharge burnup, and changes in fuel assembly designs and materials, including increased use of integral burnable absorbers, and the isotopic content of the discharged UNF. Given that the alternative fuel cycles being investigated today may not be implemented for decades, this study asserts that it is important that any separations process testing be performed with UNF that is expected to be similar to that which would be available decades from now, consistent with the anticipated time frame for potential deployment of an alternative fuel cycle. As a result, it is expected that recently discharged UNF with characteristics most similar to projected future discharged UNF (e.g., high burnup, high initial enrichment, and modern fuel design) would be most useful to the RD\&D program. At the same time, there is a potential need for UNF that has spent significant time in storage since there are fuel cycle options that use such storage as an integral part of the fuel cycle to take advantage of the change in composition resulting from radioactive decay.

To illustrate the variation in the composition of the commercial UNF assemblies in the UNF inventory through 2002, with respect to reactor type, discharge burnup, and post-irradiation cooling time, the ${ }^{239} \mathrm{Pu}$ equivalence $^{21}$ is plotted in Figure 16 and Figure 17 for a thermal and fast reactor, respectively. The ${ }^{239} \mathrm{Pu}$ equivalence is a comparative parameter that was developed such that all fuel with the same ${ }^{239} \mathrm{Pu}$ equivalence will achieve the same reactivity lifetime and discharge burnup and maintain similar local 
power peaking factors and other safety-related fuel parameters. The ${ }^{239} \mathrm{Pu}$ equivalence is also a function of the subsequent reactor the plutonium will be used within. For a simple comparison, only two types of subsequent reactors were considered: a LWR that uses mixed oxide (MOX) fuel, Figure 16, and a fast breeder reactor similar to the Super-Phenix, Figure 17. The colors in the figures represent different discharge dates — blue being 1968 and red being 2002 — while the symbols represent reactor type - square for PWR and round for BWR assemblies. From Figure 16 it can be seen that higher burnup fuels and correspondingly recently discharged fuel produced from BWR reactors have a ${ }^{239} \mathrm{Pu}$ equivalence for thermal reactors that is lower than lower burnup fuels.

From Figure 16 it can be estimated that future discharged fuel being recycled for MOX assemblies will have a lower ${ }^{239} \mathrm{Pu}$ equivalence for BWR reactor types but should have a similar ${ }^{239} \mathrm{Pu}$ equivalence for PWR fuels. In Figure 17, it can be seen that higher burnup fuels have a higher ${ }^{239}$ Pu equivalence for fast reactors than the fuels with lower burnup. This is especially true for the PWR assemblies. From Figure 17 it can be estimated that future discharged fuel being recycled for fast reactor assemblies will have a higher ${ }^{239} \mathrm{Pu}$ equivalence for PWR and BWR reactor types.

Although the ${ }^{239} \mathrm{Pu}$ equivalence factor is shown here to illustrate the various influences on the fissile content of the UNF assemblies, it is just one of several factors to be considered when selecting UNF to support RD\&D. The specific amount of UNF that would need to be retained is difficult to estimate. Experience suggests that engineering-scale demonstrations would typically be in the range of a few MTHM per year, perhaps as high as $50 \mathrm{MTHM} /$ year, and could last for several years depending on the extent of engineering-scale testing that is required. A pilot plant to demonstrate commercial viability is expected to be in the range of up to a few hundred MTHM per year and could operate for as long as a decade. The $\sim 2000$ MTHM of UNF that is discharged annually from the current fleet of LWRs represents a continuous potential source from which retained material with characteristics of current vintage UNF could be replaced, as needed. The only category that could not be readily replaced is that of aged UNF. In that case, the UNF inventory would need to be examined for fuel of sufficiently high burnup, with a physical form at least similar to today's UNF, if not identical. Such fuel has been discharged within the past 10 years, but fuel older than 10 years tends to have considerably lower burnup (Figure 10), decreasing its similarity to the anticipated characteristics of UNF discharges decades from now. 


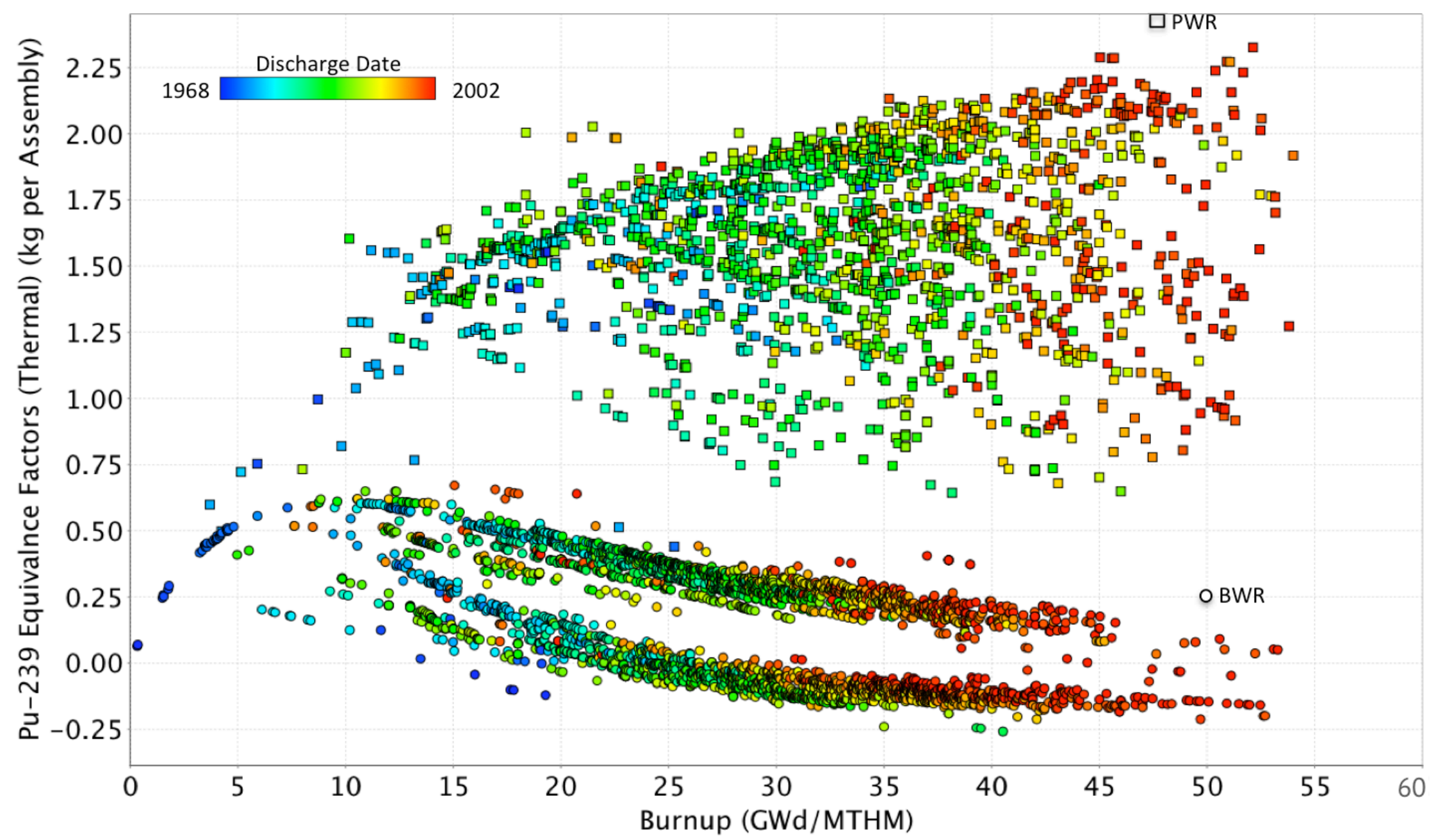

Figure 16. Plutonium-239 equivalence for a thermal reactor as a function of burnup, discharged date, and reactor type. $\underline{\text { Source: }}$ Ref. 22. 


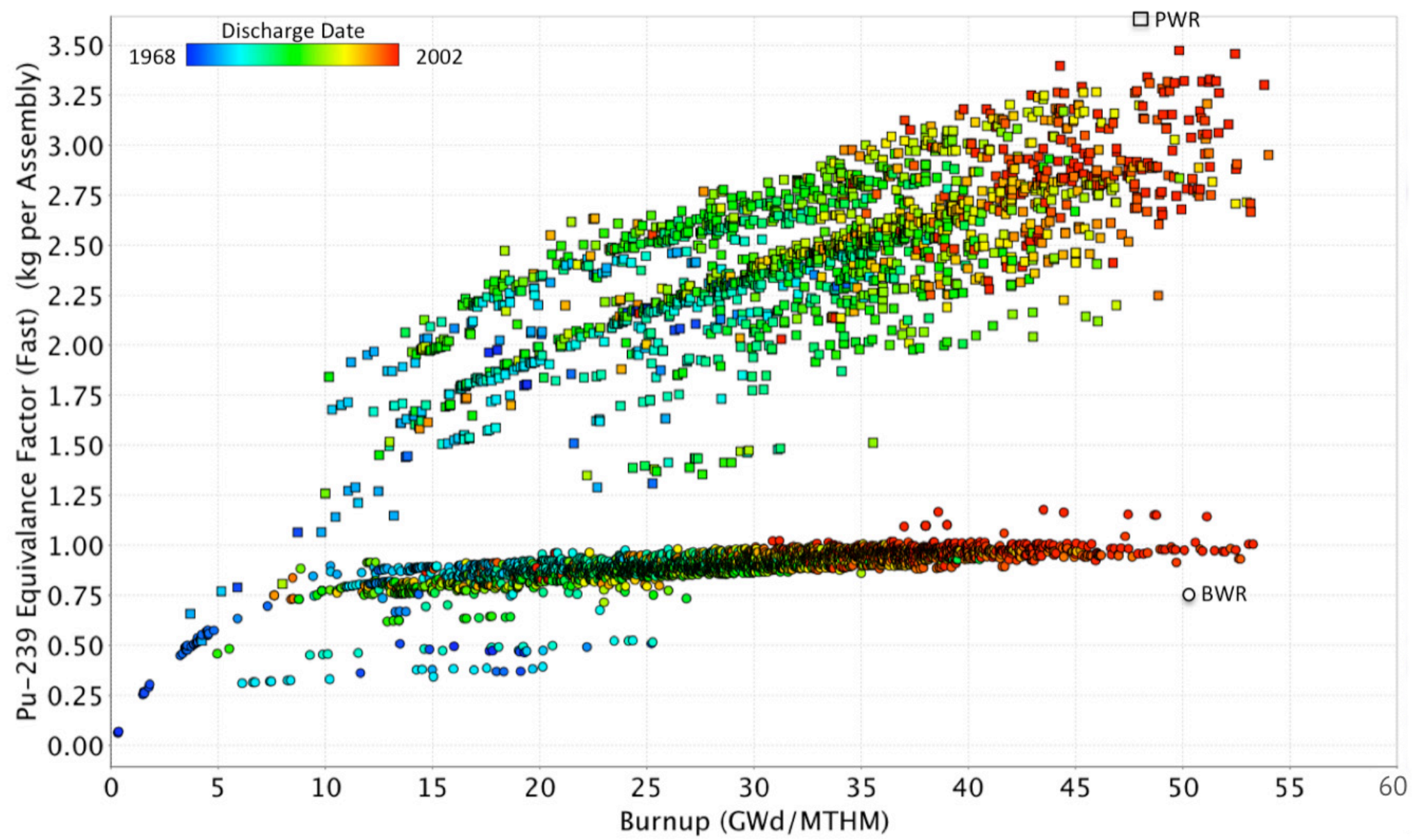

Figure 17. Plutonium-239 equivalence for a fast reactor as a function of burnup, discharged date, and reactor type. Source: Ref. 22. 


\subsubsection{Used Nuclear Fuel to Support Recycle Fuel Cycle Deployment}

Depending on the outcome of R\&D on alternative fuel cycles, as well as other nontechnical considerations, alternative fuel cycles may be deployed within the next few decades. If a recycle fuel cycle is selected for deployment, the existing UNF inventory could potentially be a resource for reprocessing. The question is whether, and how much of, the existing UNF inventory should be retained for production use in such recycle fuel cycles. To investigate this question, it is useful to consider the general characteristics of such fuel cycles, their need for UNF, and the potential deployment of these fuel cycles.

The current U.S. fleet of 104 operating reactors discharges 2000 MTHM of UNF annually. The current inventory of commercial UNF, $\sim 67,600 \mathrm{MTHM}$, is the result of reactor operation over the last $\sim 50$ years, although there were far fewer reactors in the early days of nuclear power. At the current rate of production, the current fleet will generate another $\sim 67,600$ MTHM of UNF over the next 30 years or so, a time frame that is similar to that anticipated for completing RD\&D and moving forward with deployment of a recycle fuel cycle, if the decision were made to do so. This situation is shown in Figure 18, where it can be seen that the disposal of almost the entire current inventory of UNF would have no impact on the ability to accumulate new UNF prior to the potential deployment of a recycle fuel cycle. This figure shows the total current UNF inventory in 2011 and designates all but 1700 MTHM for disposal. For UNF generated in subsequent decades, the figure identifies the material for disposal and retention assuming a constant discharge rate of $2000 \mathrm{MTHM} / \mathrm{y}$, a recycling strategy using 5-y cooled UNF implemented by 2030, and a corresponding reprocessing rate so that the UNF inventory stabilizes, in this case at around 20,000 MTHM. Note that UNF is systematically retained for RD\&D purposes prior to 2025 , after which the UNF is retained principally for recycling. This is only one example deployment scenario for a recycle fuel cycle, and many others can be proposed, but this example illustrates the point that at the current generation rate for UNF, if a decision is made to move towards a recycle fuel cycle, there is ample time to accumulate a stockpile of UNF to support it. As a consequence, this study concludes that there is no compelling reason to retain any of the existing UNF inventory for production recycling purposes in the future.

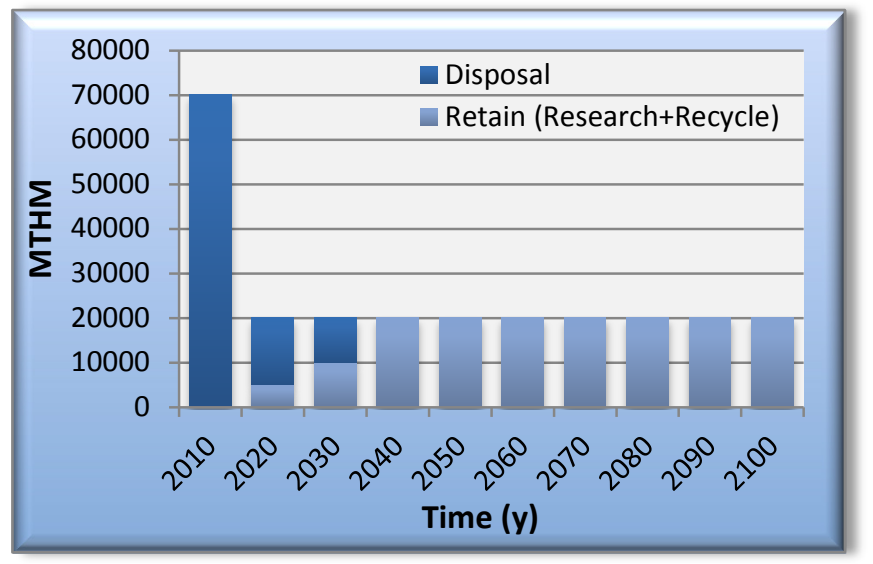

Figure 18. Categorization of UNF assuming current discharge rate and recycling beginning in 2030.

Another consideration for the use of UNF for recycle is related to the design optimization and operation of the reprocessing facility. The recycling plant will involve several steps in processing of the UNF with 
the first process being receipt of the UNF and chopping operation that precedes separation of the fuel material from the cladding. The design of the front-end process must account for variations in the fuel assembly designs, including geometry, mass, and structure. To maximize the facility reliability and throughput, as well as to reduce the initial facility cost, it is advantageous to limit the range of fuel types that the facility must accommodate. As previously discussed, since the fuel designs are converging to a relatively few common designs, the current and future UNF discharges would have the most advantages for optimizing the front-end design and facility operations. Hence, the older fuel, and much of the current UNF inventory, would not be desirable feedstock as it differs from the large amount of available nearly uniform design UNF that will be discharged in the future.

It is useful to note that the only exception to the above conclusion is the case where a rapid deployment of certain fuel cycles would be anticipated. There are fuel cycles ${ }^{23}$ based on deployment of high conversion or breeder reactors, where the ability to deploy the advanced reactors depends on the availability of elements that are present in the UNF, and having a greater stockpile of UNF may enable a more rapid deployment. One example of such a system would be the rapid deployment of fast reactors using plutonium as the initial start-up charge. These reactors require nominally 5-10 tonnes plutonium/GWe, which would amount to processing 1000 MTHM of used LWR fuel. With 2000 MTHM of LWR UNF being produced annually, fast reactor deployment of 2-4 GWe annually could be supported. If the rapid deployment were to exceed this growth rate, previous stockpiles would be necessary or enriched uranium would have to be substituted for plutonium start-up fuel. However, this would only be possible if reprocessing capability were rapidly deployed that significantly exceeds the current production rate of 2000 MTHM per year.

As another specific example scenario in which fast reactors take on a prominent role, consider a fuel cycle option in which the United States deploys fast reactors after the year 2050, at which time it is expected that technology would be available for commercial deployment. The U.S. electricity demand is expected to grow at approximately $1 \%$ per year, ${ }^{24}$ and assuming nuclear is to maintain its current market share of electricity, the U.S. nuclear capacity will double before 2100. In this example scenario, all of the newly built reactors that are constructed to address the growth requirements and to replace the closing LWR fleet after 2050 are fast reactors; until that time new LWRs are built. Even in this scenario it has been shown that there is sufficient plutonium available in the LWR UNF from 2020 onwards to fuel all of the future fast reactors as they reach equilibrium with self-sustaining plutonium recycle. This would require reprocessing of the LWR fuel to start several years prior to the first fast reactor coming online to develop sufficient material for reactor startup (Figure 19). 


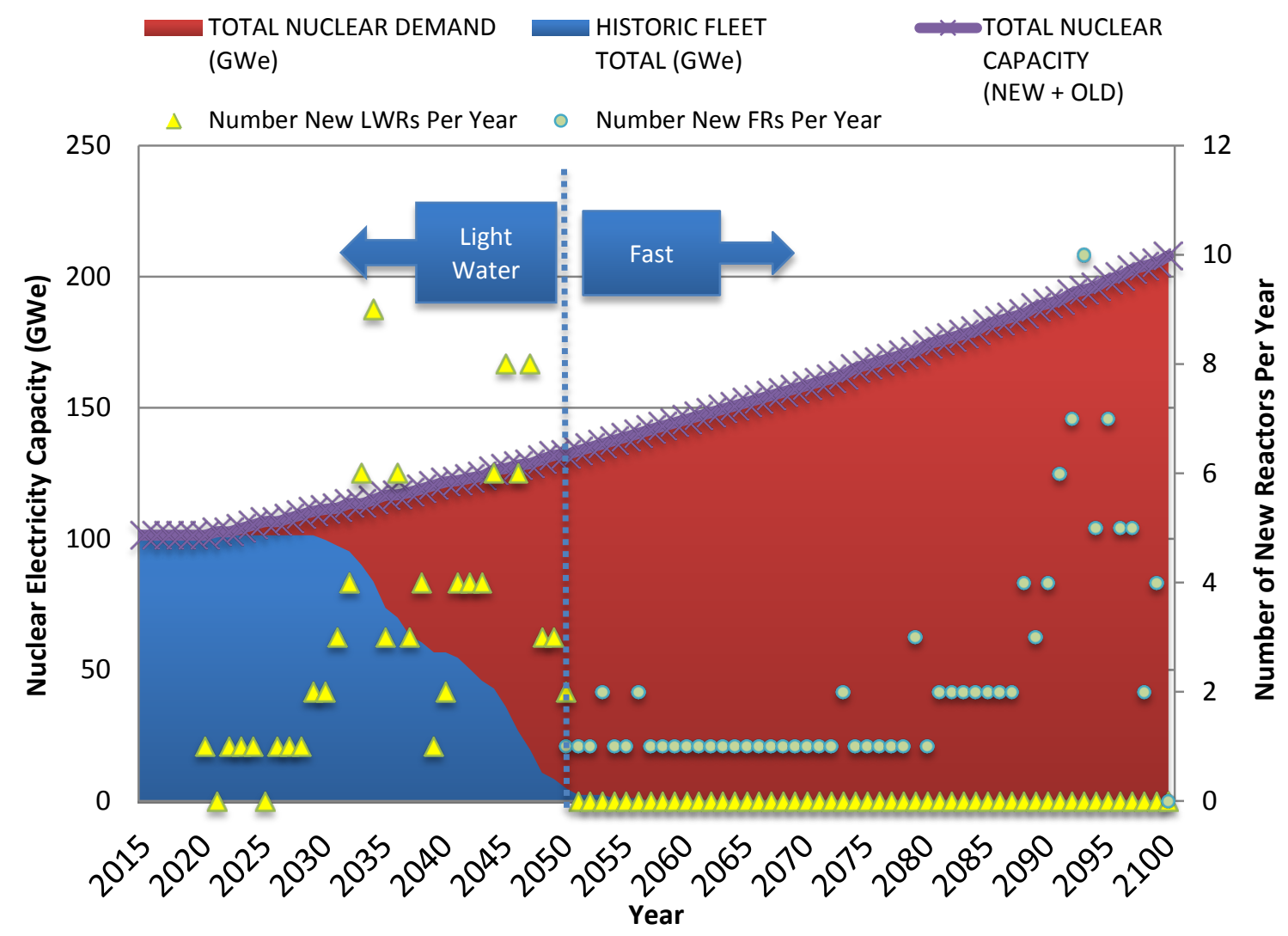

Figure 19. Predicted number of light water reactors and fast reactors required to match potential nuclear growth scenario. Source: Ref. 25.

While these example fast-reactor deployment scenario exceptions are in contradiction with several of our key assumptions (Section 3.1), the conclusion that the existing inventory of LWR UNF is not needed remains valid.

\subsection{NATIONAL SECURITY}

Highly enriched uranium UNF may be useful to support national security missions and represents a small fraction of the current UNF inventory ( 50 MTHM with an enrichment greater than $\left.90 \mathrm{wt} \%{ }^{235} \mathrm{U}\right)$. This material represents U.S.-origin enriched uranium that is not subject to international consent agreements. For example, it could be used to offset the need for a dedicated enrichment plant to support national security missions. Given the special nature of this material, it is recommended that a study be conducted to evaluate the benefits of recovering this material. 


\section{CRITERIA FOR USED NUCLEAR FUEL CATEGORIZATION}

Based on the assessment of UNF relative to retention needs discussed in the previous section, it is proposed that the current UNF inventory can be divided into the following three categories - disposal, research, and recycle. These categories and attributes and issues affecting categorization of the UNF inventory relative to these categories are discussed in this section.

\subsection{USED NUCLEAR FUEL CATEGORIES}

\subsubsection{Disposal}

This category is for excess material that is not needed for other purposes. For material in this category, it is judged that the liabilities associated with maintaining access to the material exceed the value to the nation, and that there is high confidence that this determination will not change in any reasonably foreseeable future scenario. Further, this category is defined to be consistent with The Nuclear Waste Policy Act ${ }^{26}$ definition of "disposal" in that for material to be placed in this category, there is "no foreseeable intent of recovery" from disposal. Categorization of UNF for disposal does not require a determination that it has no value. In principle, all irradiated fuel has some potential value as an energy source. The determination instead supports a comprehensive national fuel cycle strategy.

\subsubsection{Research}

This category is for UNF material that may be needed to support the DOE-NE RD\&D programs and objectives, as well as RD\&D for the broader nuclear energy enterprise. Currently, retention of access to material in this category is anticipated for RD\&D purposes to support UNF management (e.g., UNF storage, transportation, and disposal) and development of alternative fuel cycles as specified in the DOE-NE Roadmap. For any material placed in this category, it is judged that access to that material should be preserved to support RD\&D programs.

\subsubsection{Recycle/Recovery}

This category is for UNF material that may be needed as feedstock for production-scale (beyond RD\&D) recycling as part of a recycle fuel cycle, as well as UNF material that may be needed to support national security interests. This category includes commercial UNF for recycle to commercial systems as well as recovery of strategic materials, such as the HEU UNF. For any material placed in this category, it is judged that access to that material should be preserved for recycling or recovery purposes.

\subsection{ATTRIBUTES AND ISSUES AFFECTING CATEGORIZATION}

\subsubsection{Disposal}

The primary attribute that defines UNF categorized for disposal is, at the most basic level, that it not be categorized as warranting retention for other purposes. Further, as discussed in the subsection that follows, that there is no foreseeable intent of recovery from disposal following emplacement. Various types of UNF may have different characteristics that have the potential to affect disposal system performance (e.g., UNF with high thermal output may require additional consideration in disposal system operations or design), but ultimately, a repository must be capable of receiving any material for which

there is no alternative disposition pathway. Past analyses ${ }^{27-31}$ of a range of repository concepts in the United States and elsewhere indicate that robust isolation can be achieved for a broad range of UNF types. In this work, categorization of UNF for retention will primarily be based on other attributes, as described in the following sections. 


\subsubsection{Retrievability}

The Nuclear Waste Policy Act ${ }^{26}$ defines "disposal" to mean "the emplacement in a repository of highlevel radioactive waste, spent nuclear fuel, or other highly radioactive material with no foreseeable intent of recovery, whether or not such emplacement permits the recovery of such waste." Usage in this report is entirely consistent with this definition: the categorization of UNF as being suitable for direct disposal in a repository carries an implicit acknowledgment that there are no foreseeable circumstances under which the DOE might choose to retrieve the material from the repository for subsequent reuse.

Regardless of the determination that there is "no foreseeable intent of recovery" of UNF once it has been emplaced in a repository, there are legal and regulatory requirements that material be retrievable from repositories. Specifically, the NRC requires in 10 CFR $60.111(\mathrm{~b})(1)^{a}$ that "the geologic repository operations area shall be designed so that any or all of the emplaced waste could be retrieved on a reasonable schedule starting at any time up to 50 years after waste emplacement operations are initiated, unless a different time period is specified by the Commission." The Environmental Protection Agency (EPA), at 40 CFR 191.14(f), took a slightly different approach, by requiring that "disposal systems shall be selected so that removal of most of the wastes is not precluded for a reasonable period after disposal," but further noted that "the intent of this provision was not to make recovery of waste easy or cheap, but merely possible in case some future discovery or insight made it clear that the wastes needed to be relocated." 32 In addition, with the Blue Ribbon Commission's observed that these requirements "are not intended for the purpose of retaining easy access to emplaced materials for possible later recovery or reuse." ${ }^{33}$ The DOE will not emplace material in a repository if there is intent to reuse it at a later date. It will also ensure that any repository meets legal and regulatory requirements for retrievability if necessary.

\subsubsection{Research}

For RD\&D to support UNF management, including storage, transportation, and disposal, the most useful UNF would be that which represents the full range of parameters characterizing the current discharged inventory. Due to the significant diversity in the current UNF inventory, a set of selection criteria was developed and grouped into the following two main categories: (1) assembly design and (2) assembly exposure and operating history. The characteristics that are most relevant are described in Section 3.2.2 and comprise the fuel assembly design, including materials, exposure conditions and discharge burnup, and cooling time and post-irradiation storage conditions. Access to a sufficient quantity of representative commercial UNF is needed to support planned R\&D efforts and to be available to support addressing questions or issues that may arise in the future.

For RD\&D to support development of alternative nuclear fuel cycles, per the DOE-NE Roadmap, the most useful UNF would be that which best represents UNF expected to be discharged one or more decades from now, at about the time when a recycle fuel cycle might be deployed. Older fuel can also be used for RD\&D of the separations and treatment technologies and advanced fuel development at the laboratory and engineering scales. The characteristics that are most relevant are the fuel type and characteristics, such as inclusion of burnable absorbers, the discharge burnup, and the cooling time. This would provide UNF of the appropriate composition, and with the corresponding physical fuel conditions, cladding conditions, and such that would make technology development and testing relevant for use with future UNF discharges.

\footnotetext{
${ }^{a}$ Note that currently applicable regulations may change as a new U.S. policy regarding nuclear waste management evolves.
} 


\subsubsection{Recycle/Recovery}

For production-scale recycling as part of a sustainable full-recycle fuel cycle strategy, there are a number of considerations that influence the decision on the UNF feedstock characteristics that are most useful and/or preferred. These include, but are not limited to the following.

- characteristics of the new fuel to be produced

- isotopic composition of the UNF feedstock, which dictates energy content and impacts facility design and operations in terms of decay heat, radiation dose rates, and criticality safety

- variability of the isotopic compositions in the UNF feedstock, for example, due to variability in assembly initial enrichment, burnup, and decay time, which impacts operations to satisfy tolerance requirements for the new fuel to be produced

- total fissile mass per UNF feedstock assembly

- physical variability of the UNF feedstock, for example, due to variability in assembly mass, cladding materials, non-fuel hardware components, and possible degradation (e.g., oxidation of cladding), which impacts head-end design, operations and operational throughput, and facility reliability

- availability of UNF feedstock for the intended lifetime of the facility

- accessibility to the UNF feedstock, for example, accessibility and operations associated with using UNF assemblies loaded into a variety of dry storage cask systems may be different from using UNF assemblies taken directly from wet storage

Each of these considerations impacts the cost of the recycling facility in terms of initial design, licensing, construction, and operation. ${ }^{34,35}$

The timing selected for initial separation of UNF is especially important and has been studied extensively. Older UNF (e.g., discharged 30 or more years prior to recycling) has distinct advantages in head-end processing as the decay of fission products minimizes issues with fission gas capture, decay heat, radiation dose rates, and waste management. ${ }^{36}$ On the other hand, UNF loses fissile ${ }^{241} \mathrm{Pu}$ to ${ }^{241} \mathrm{Am}$ with aging, significantly reducing the energy content of the UNF. The loss of ${ }^{241} \mathrm{Pu}$ has resulted in the standard commercial approach of recycling UNF to make MOX LWR fuel following a post-irradiation cooling time of approximately 5 years. The discharge isotopic composition of a Westinghouse Electric (WE) $17 \times 17$ assembly with initial enrichment of $4.5 \mathrm{wt} \%$ that has accumulated $45 \mathrm{GWd} / \mathrm{MTU}$ burnup is shown in Figure 20 for reference purposes. 


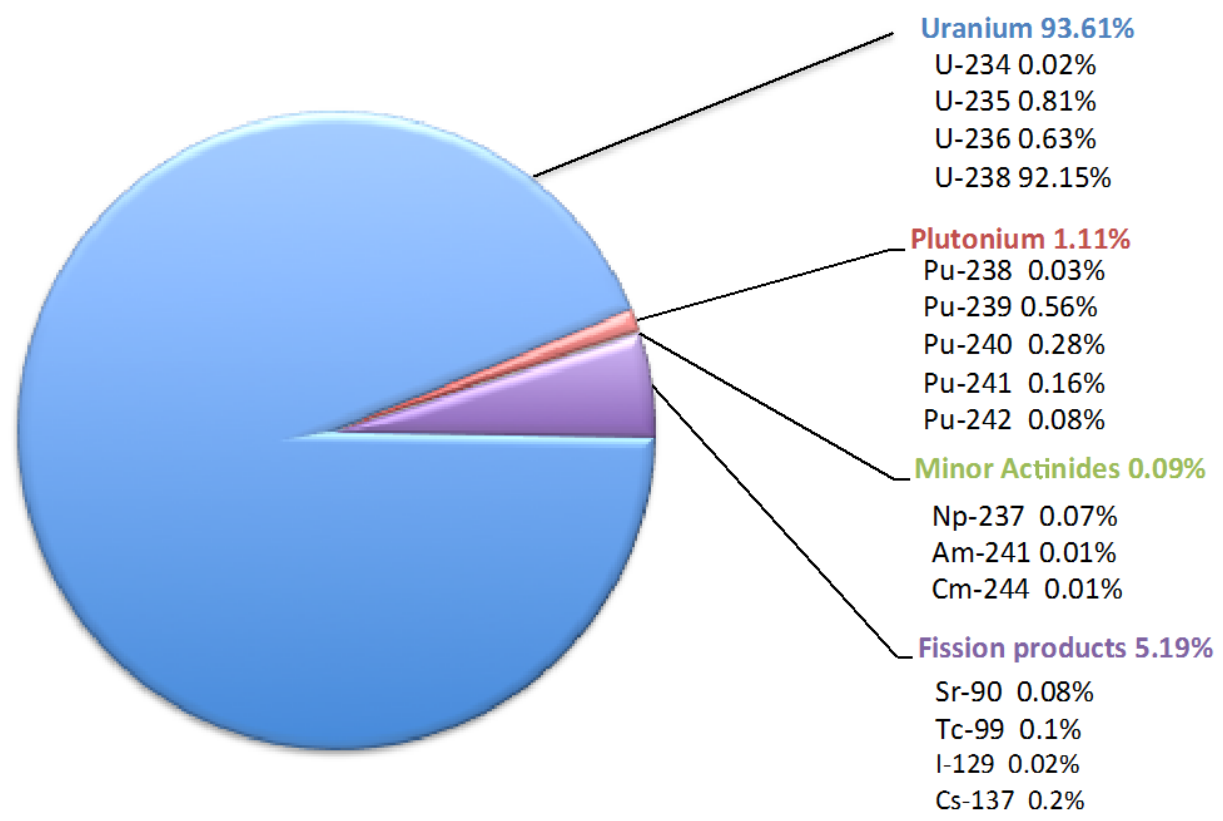

Figure 20. Discharge isotopic composition of a WE $17 \times 17$ assembly with initial enrichment of $4.5 \mathrm{wt} \%$ that has accumulated $45 \mathrm{GWd} / \mathrm{MTU}$ burnup.

The isotopic composition of recycled plutonium is a function of the total burnup, reactor type, initial enrichment, and, as mentioned, time after discharge of the UNF. As seen in Figure 21, plutonium continues to increase with burnup; however, only ${ }^{239} \mathrm{Pu}$ and ${ }^{241} \mathrm{Pu}$ are fissile, and although dependent on a number of factors, those isotopes generally do not continue to increase significantly at higher burnup. In addition, ${ }^{241} \mathrm{Pu}$ has a relatively short half-life (14.4 years). 


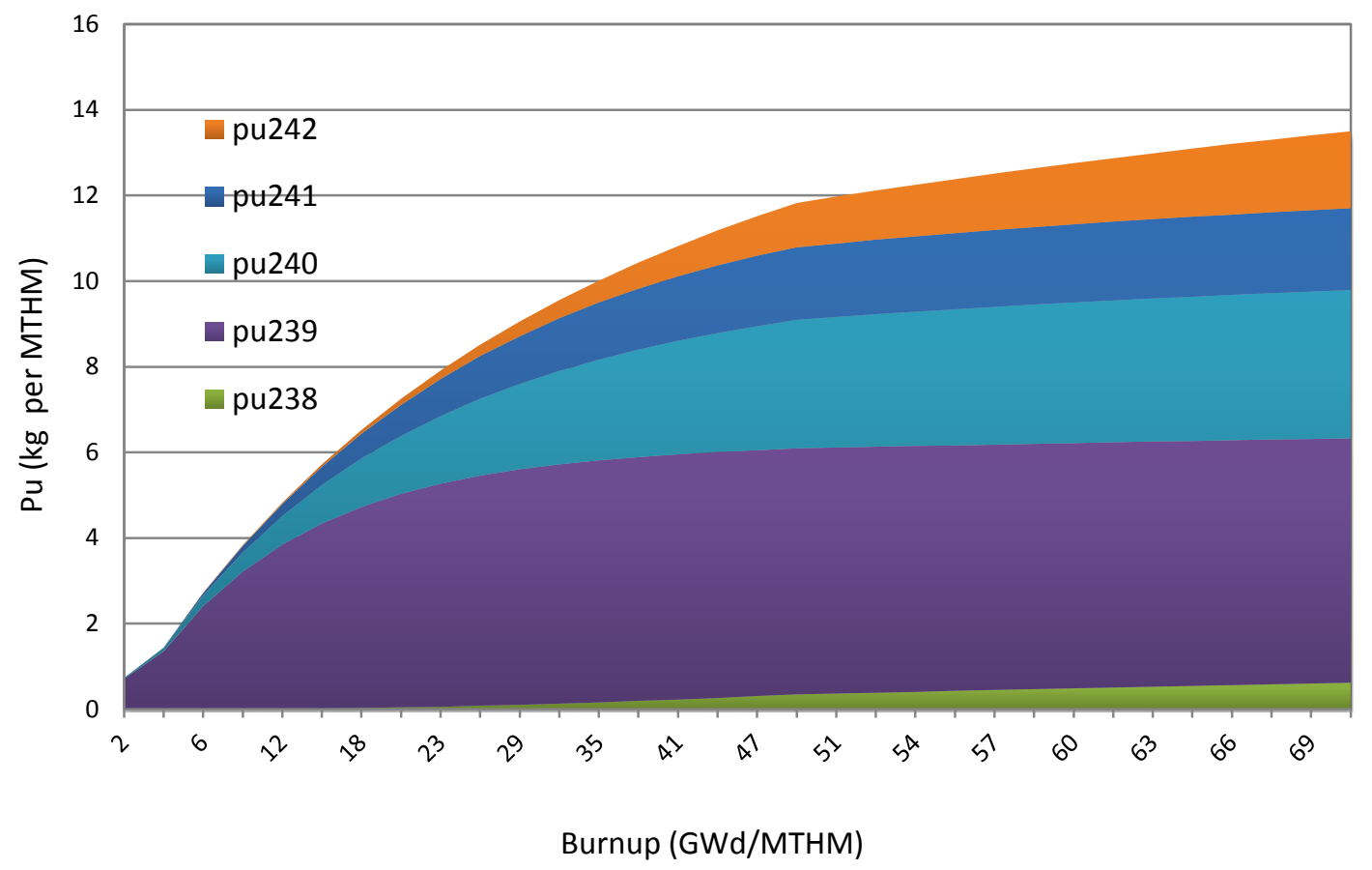

Figure 21. Isotopic composition of used nuclear fuel as a function of burnup for a generic PWR $17 \times 17$ assembly for zero cooling time.

In a previous study ${ }^{37}$ that investigated prioritization of criteria for selecting UNF for recycling, plutonium concentrations as a function of both burnup and decay time were correlated with a parameter called the support ratio. The support ratio was defined to be the amount of discharged LWR UNF that would need to be recycled to produce the same energy content within the reactor. The higher the support ratio, the larger the mass of fuel that would need to be reprocessed to obtain the equivalent quantity of fissile material. The authors compared the support ratio for both PWR and BWR UNF and showed that even though longer burnup increases the production of undesirable plutonium isotopes, such as ${ }^{242} \mathrm{Pu}$, it also results in the highest fissile content. It was also shown that fuels with shorter cooling times following discharge also contain higher fissile content. From an energy content perspective, these results confirm the desirability of reprocessing high-burnup UNF with short cooling times. As the current inventory of UNF tends to have lower burnup and longer cooling time, as compared to recently and/or to-be-discharged UNF, on a per mass basis, the quantity of fissile material in the current inventory of UNF is generally lower (on a per-assembly basis) than that of future discharged UNF. This lower content implies the need to process more fuel assemblies to recover a given amount of fissile material, which will result in additional processing cost. For this reason, the newly available or future UNF is attractive for advanced recycling. The newly available or future UNF can, however, put some stringent requirements on the design and operation of the recycling facilities to ensure workers' safety from the higher radiation from such UNF.

From an engineering and operational point of view, uniformity between assemblies is also an important aspect to take into consideration. This is because the fuel recycling facility and the fuel fabrication facility will require remote handling and automation for most of the processes. Remote handling and automation add a complexity to the overall process; therefore, having an input stream with very similar characteristics can decrease the facility design, construction, and operational costs and potentially greatly 
improve operational reliability and throughput. Another important consideration is the fissile mass per assembly - the higher the fissile mass, the fewer the number of assemblies that must be processed to obtain a given fissile mass of new fuel, which improves operational throughput and facility efficiency. Figure 22 shows the variability in initial uranium mass in the 22 assembly classes present in the current UNF inventory. Given that the new PWR reactor designs for which COL applications have been submitted (i.e., AP1000, U.S. EPR, and U.S. APWR), all intend to use the same assembly lattice size (i.e., $17 \times 17)$ and length (14 ft), and the high initial uranium mass per assembly associated with the $17 \times 17$ lattice size, as shown in Figure 22. Future discharges of high-burnup $17 \times 17$ assemblies appear to be a good potential source for recycling feedstock.

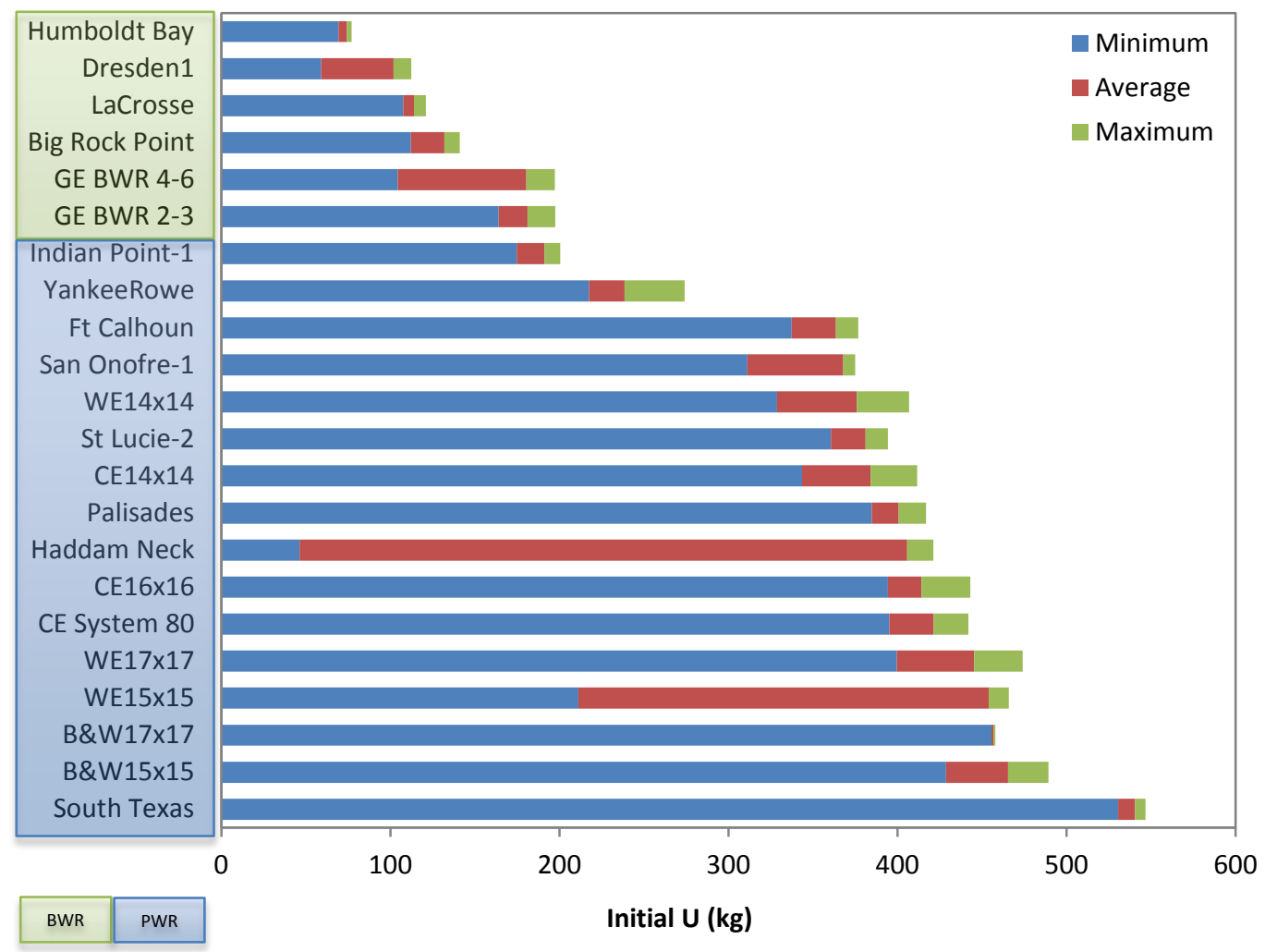

Figure 22. Distribution of assembly initial uranium mass by assembly class in the commercial UNF inventory as of 2002. Source: Ref. 5.

Based on the preceding discussion and previous studies, it is judged that the most useful material for production-scale recycling has the following attributes: high burnup, relatively short cooling time, and, to the extent possible, uniformity in fuel design and discharge characteristics. An inherent assumption in this judgment is that the recycling is focused on recovering the plutonium energy resource. Recovery of residual uranium was considered, but given that the residual fissile $\left({ }^{235} \mathrm{U}\right)$ uranium content in currently discharged UNF is near or below the content available in natural uranium and the current cost and availability of natural uranium, recovery of uranium from UNF is not anticipated to be a key factor in a future decision on pursuing production-scale recycling.

If a decision is made in the future to proceed with production-scale recycling, the above discussion supports the assumption that, to be sustainable, the fuel cycle would be based on UNF discharges at that time. In other words, that a future recycling facility would not likely be designed and optimized for UNF 
feedstock that is no longer being produced. Part of the basis for this assumption is that the United States is currently discharging 2000 MTHM annually, and hence by the time production-scale recycling would be deployed, the United States will have plenty of additional UNF material that is better suited to production-scale recycling than the current UNF inventory (i.e., high burnup, shorter cooling time, and more uniform design and discharge characteristics). Therefore, the most useful UNF material is that which best represents the UNF expected to be discharged at the time when the recycle fuel cycle is to be deployed.

For recovery, the potential strategic value of the material is considered, particularly for national security interests. The primary attribute that defines UNF categorized for recovery is the residual ${ }^{235} \mathrm{U}$ enrichment. Domestically generated UNF is not subject to international consent agreements, and hence material with high residual ${ }^{235} \mathrm{U}$ enrichment could be recovered from HEU UNF and used to offset the need for a dedicated enrichment plant to support national security missions. For example, HEU UNF could be processed to recover the HEU, which could then be down-blended to produce enriched material to support national security missions. 



\section{RESULTS OF CATEGORIZATION}

Based on the assessment of UNF relative to retention needs, time frames in which recycle fuel cycles could be realistically deployed, and possible uses to support national security interests, the current (as of 2011) UNF inventory is categorized in this section according to the three categories described Section 4.1.

\subsection{DISPOSAL}

The current UNF in this category is that which is categorized as not warranting retention for other purposes, and hence is the total current UNF inventory minus the material designated for either the research or recycle/recovery categories.

The $\sim 2500$ MTHM of DOE-owned UNF is currently designated by the DOE Office of Environmental Management (EM) for disposal and was included in this report for completeness. With the exception of the small fraction that contains HEU, the DOE-owned UNF was not independently assessed here. Until and unless determined otherwise, the 2500 MTHM of DOE-owned UNF is designated for disposal, except for the small fraction that contains HEU.

As a result of consideration of the needs of the DOE-NE RD\&D programs and objectives, as well as $\mathrm{RD} \& \mathrm{D}$ for the broader nuclear energy enterprise, time frames in which recycle fuel cycles could be realistically implemented, and possible uses to support national security interests, it is proposed that $\sim 68,450$ MTHM ( 66,000 MTHM of commercial and $\sim 2500$ MTHM of DOE owned) of the current (as of 2011) UNF inventory should be placed in the disposal category and permanently disposed, without the need to make fuel retrievable from disposal for reuse or research purposes.

\subsection{RESEARCH}

In the following subsections, it is estimated that access to up to 1,700 MTHM of the current (as of 2011) commercial UNF inventory be retained to support RD\&D for UNF management and alternative fuel cycles.

\subsubsection{Used Nuclear Fuel Management}

As was discussed in Section 3.2, there is a recognized need to maintain access to a sufficient quantity of representative samples of commercial UNF to support UNF management, including storage, transportation, and disposal. Selection of UNF assemblies for retention is complicated by the use of a wide variety of fuel assembly designs in the various PWR and BWR designs, the significant variations in exposure and operating history, and the need to retain to sufficient quantities of these variations to enable reliable statistical analyses. With consideration of these variations and potential RD\&D needs to support UNF management, a set of selection criteria were developed and described in Section 3.2.2. Based on these selection criteria, it is recommended that access be retained to each of the significant fuel assembly design variations in the current inventory, which will provide representative samples and sufficient quantities from each reactor type (i.e., BWR and PWR) and design (i.e., Westinghouse, Combustion Engineering, B\&W, General Electric, etc.). For each of these significant fuel assembly design variations, it is recommended that access be retained to UNF assemblies representing the full range of important design variations, such as cladding materials and integral burnable absorbers, fuel assembly burnup values, and post-irradiation cooling times. Finally, for selected assembly designs, it is recommended to retain access to assemblies that experienced varying reactor operating conditions and post-irradiation storage conditions, and assemblies with varying post-irradiation physical conditions of interest (e.g., bowing, other forms of damage, and rod consolidation). It is important to note that a number of these 
selection criteria are overlapping. For example, UNF assemblies of a given assembly type that span the representative range of burnup values and cooling times may also cover some or all of the range of operating conditions and post-irradiation storage conditions of interest.

For reasons related to practicality of operations, it may not be possible, particularly in the near term, to select individual UNF assemblies for access retention. Rather, to retain access to UNF assemblies of interest, it may be necessary to retain access to dry storage casks that are loaded with the UNF assemblies of interest. Given the manner in which dry storage casks are typically loaded (e.g., to balance total package thermal limits), loaded casks are expected to provide some of the variability (e.g., variations in fuel burnup, cooling times, and fuel assembly design variations) recommended above for UNF management. However, if UNF assembly selection is based on loaded casks (i.e., for a cask that has one or more assemblies of interest, the entire cask load is retained), it is expected that the total amount of UNF that would be retained will be greater than if selection was based on individual assemblies.

Furthermore, most of the UNF-related issues of interest to UNF management are related to fuel rod materials and their performance, ${ }^{12}$ and hence $\mathrm{RD} \& \mathrm{D}$ to resolve these issues may only require access to fuel rods, as opposed to fuel assemblies. Therefore, retention of UNF assemblies, as opposed to rods, will also contribute to the retention of more UNF material than is actually needed for the RD\&D. This may actually be viewed as a positive aspect, given that it will result in some, potentially significant, amount of excess material that will help to provide assurance that any future retrievability from disposal will not be necessary. As the RD\&D programs proceed, future implementation efforts may work to enable the retention of individual rods, as opposed to assemblies, and assemblies, as opposed to casks, according to the specific RD\&D material needs.

With these practicalities in mind, recommendations on the amount of UNF for which access should be retained to support UNF management RD\&D are presented in Table 1. For high-capacity rail casks, the low end of the range (i.e., 200 MTHM) may be acceptable if the selection process includes provisions for identifying and custom loading of casks to optimize the representation of the selected fuel assemblies. For example, for a given lattice, one large cask might be filled with assemblies representing the design and operational variations experienced at a plant, another large cask could be loaded with otherwise similar assemblies having assembly burnup values spread over the relevant range, and a third cask with assemblies having cooling times spread over the relevant range. Of course, this low-end estimate would require considerable coordination with industry and may not fully accommodate future RD\&D needs. The high end of the range (i.e., $~ 1146$ MTHM) may be necessary if candidate casks must be selected from already-loaded casks and/or if it is decided that access to some of each of the reactor-specific assembly types must be retained. Note, for example, that some of the reactor-specific fuel types, such as Yankee Rowe and La Crosse, are fully loaded in dry storage casks. Hence, the high end of the range may be needed to support retention of all relevant design and operational variations and a reasonably complete distribution of assembly discharge burnup values and post-irradiation cooling times. At this point, it is decided to err on the side of inclusion, such that future refinements of the selection criteria and RD\&D needs and/or coordination with industry or a future consolidated storage site to enable access to specific assemblies and/or rods might reduce the variety and amount of material for which access is retained. Therefore, based on this assessment, it is suggested that access to up to 1146 MTHM of the current commercial UNF be retained to support UNF management RD\&D. 
Table 1. Estimated mass of UNF for which access should be retained to support UNF management R\&D

\begin{tabular}{|c|c|c|c|c|c|c|c|c|c|}
\hline \multicolumn{10}{|c|}{ PWR UNF } \\
\hline $\begin{array}{l}\text { Assembly } \\
\text { design }\end{array}$ & $\begin{array}{c}\text { Average } \\
\text { MTHM } \\
\text { per } \\
\text { assembly }\end{array}$ & $\begin{array}{c}\text { MTHM per } \\
\text { truck cask } \\
(4 \text { assemblies } \\
\text { per cask) }^{a}\end{array}$ & $\begin{array}{l}\text { Number of } \\
\text { truck casks }\end{array}$ & $\begin{array}{l}\text { Total } \\
\text { MTHM for } \\
\text { truck casks }\end{array}$ & $\begin{array}{c}\text { MTHM per } \\
\text { rail cask } \\
\text { (32 assemblies } \\
\text { per cask) }\end{array}$ & $\begin{array}{l}\text { Number } \\
\text { of rail } \\
\text { casks }\end{array}$ & \multicolumn{3}{|c|}{$\begin{array}{l}\text { Total MTHM for } \\
\text { rail casks }\end{array}$} \\
\hline CE $14 \times 14$ & 0.384 & 1.536 & 15 & 23.04 & 12.29 & 2 to 10 & 24.58 & to & 122.88 \\
\hline CE $16 \times 16$ & 0.417 & 1.668 & 15 & 25.02 & 13.34 & 2 to 10 & 26.69 & to & 133.44 \\
\hline B\&W $15 \times 15$ & 0.465 & 1.860 & 15 & 27.90 & 14.88 & 2 to 10 & 29.76 & to & 148.80 \\
\hline WE $14 \times 14$ & 0.376 & 1.504 & 15 & 22.56 & 12.03 & 2 to 10 & 24.06 & to & 120.32 \\
\hline WE $15 \times 15$ & 0.454 & 1.816 & 15 & 27.24 & 14.53 & 2 to 10 & 29.06 & to & 145.28 \\
\hline WE $17 \times 17$ & 0.445 & 1.780 & 15 & 26.70 & 14.24 & 2 to 10 & 28.48 & to & 142.40 \\
\hline All PWR & & & 90 & 152.46 & & 12 to 60 & 162.62 & to & 813.12 \\
\hline \multicolumn{10}{|c|}{ BWR UNF } \\
\hline $\begin{array}{c}\text { Assembly } \\
\text { design }\end{array}$ & $\begin{array}{c}\text { Average } \\
\text { MTHM } \\
\text { per } \\
\text { assembly }\end{array}$ & 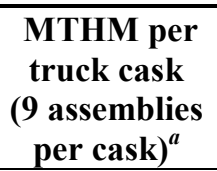 & $\begin{array}{l}\text { Number of } \\
\text { truck casks }\end{array}$ & \begin{tabular}{l}
\multicolumn{1}{c}{ Total } \\
MTHM for \\
truck casks
\end{tabular} & $\begin{array}{c}\text { MTHM per } \\
\text { rail cask } \\
\text { (68 assemblies } \\
\text { per cask) }\end{array}$ & $\begin{array}{l}\text { Number } \\
\text { of rail } \\
\text { casks }\end{array}$ & \multicolumn{3}{|c|}{$\begin{array}{c}\text { Total MTHM for } \\
\text { rail casks }\end{array}$} \\
\hline GE $6 \times 6$ & 0.097 & 0.873 & 7 & 6.11 & 6.60 & 1 to 6 & 6.60 & to & 39.58 \\
\hline GE $7 \times 7$ & 0.191 & 1.719 & 7 & 12.03 & 12.99 & 1 to 6 & 12.99 & to & 77.93 \\
\hline GE $8 \times 8$ & 0.180 & 1.620 & 7 & 11.34 & 12.24 & 1 to 6 & 12.24 & to & 73.44 \\
\hline GE $9 \times 9$ & 0.171 & 1.539 & 7 & 10.77 & 11.63 & 1 to 6 & 11.63 & to & 69.77 \\
\hline GE $10 \times 10$ & 0.176 & 1.584 & 7 & 11.09 & 11.97 & 1 to 6 & 11.97 & to & 71.81 \\
\hline All BWR & & & 35 & 51.35 & & 5 to 30 & 55.42 & to & 332.52 \\
\hline \multicolumn{10}{|c|}{ PWR \& BWR UNF } \\
\hline BWR \& PWR & & & 125 & 203.81 & & 17 to 90 & 218.04 & to & 1145.64 \\
\hline
\end{tabular}

${ }^{a}$ Capacity based on the GA-4 and GA-9 cask designs. ${ }^{38}$ 


\subsubsection{Alternative Fuel Cycles}

As was discussed in Section 3.3, there is a recognized need to maintain access to representative samples and sufficient quantities of commercial UNF to support RD\&D for alternative fuel cycle options. The amount of UNF that would need to be retained for such RD\&D is difficult to estimate. Experience suggests that engineering-scale demonstrations would typically be in the range of a few MTHM per year, perhaps as high as $50 \mathrm{MTHM} / \mathrm{year}$, and could last for several years depending on the extent of engineering-scale testing that is required. A pilot plant to demonstrate commercial viability is expected to be in the range of up to a few hundred MTHM per year, and could operate for as long as a decade. Considering the potential need for up to $50 \mathrm{MTHM} / \mathrm{y}$ over the next decade to support RD\&D and potential engineering-scale testing, it is suggested that access to up to $\sim 500 \mathrm{MTHM}$ of commercial UNF be retained to support alternative fuel cycle RD\&D. The UNF selected for access retention should be a mix of that which best represents UNF expected to be discharged one or more decades from now and older fuel that can be more easily used for RD\&D of separations and treatment technologies and advanced fuel development. It is noted that 2000 MTHM of UNF is discharged annually from the current fleet of LWRs, and hence the $\sim 500 \mathrm{MTHM}$ is considered an upper estimate for retention at this time. It is further noted that the amount of material retained for UNF management RD\&D may include sufficient margin to cover some portion of the RD\&D needs for alternative fuel cycles. Finally, given the desired attributes of the UNF material for recycling in an alternative fuel cycle, discussed in Section 4.2.3, it may be decided in the future that the current commercial UNF for which access is retained to support advance fuel cycle R\&D should be replaced at appropriate intervals with future discharged UNF.

\subsection{RECYCLE/RECOVERY}

As discussed above, it is not anticipated that any of the current inventory of UNF would be needed to support utilization in a deployed recycle fuel cycle. History suggests that a decision to deploy such a fuel cycle is likely decades away and dependent on the outcome of current RD\&D activities such as the Nuclear Fuel Cycle Evaluation and Screening ${ }^{39}$ and the development of advanced separations technologies, as well as a consensus on the need to deploy an alternative fuel cycle on an industrial scale. Assuming that such RD\&D indicates promise for a recycle fuel cycle sufficient to support a decision to move forward with implementation, once the decision is made, it would require at least a decade or more to design, license, and construct the facilities to support such a fuel cycle. Based on the current UNF production rate, the anticipated deployment schedule would allow sufficient time to accumulate the needed inventory to support such a fuel cycle. Therefore, it is suggested that none of the current commercial UNF be retained to support production-scale recycle at this time.

As discussed above there is up to $\sim 50$ MTHM of HEU UNF that includes material with high residual ${ }^{235} \mathrm{U}$ enrichment. This material represents U.S.-origin enriched uranium that is not subject to international consent agreements, and hence may be useful in support of national security missions. Given the special nature of this material, it is recommended that all $\sim 50 \mathrm{MTHM}$ of this material be placed into the recycle/recovery category.

\subsection{SUMMARY}

The results of the categorization discussed in the above sections are summarized in Table 2 . The estimated total amount in the Research category ( 1,646 MTHM) includes $\sim 1146$ MTHM to support UNF management RD\&D (Section 5.2.1) and $\sim 500$ MTHM to support alternative fuel cycles RD\&D (Section 5.2.2), and represents $\sim 2 \%$ (by mass) of the total UNF inventory. The estimated total amount in the Recycle/Recovery category corresponds to the $\sim 50$ MTHM of HEU UNF to support national security missions. The remainder of the total inventory, $\sim 98 \%$ (by mass), is assigned to the Disposal category. 
Table 2. Summary of UNF categorization results (units are MTHM)

\begin{tabular}{|l|r|r|r|c|}
\hline \multicolumn{1}{|c|}{ UNF Type } & \multicolumn{1}{c|}{ Total } & Disposal & Research & Recycle/Recovery \\
\hline Commercial & 67,600 & 65,954 & 1,646 & 0 \\
\hline DOE owned & 2,500 & 2,500 & 0 & 0 \\
\hline HEU & 50 & 0 & 0 & 50 \\
\hline Total & 70,150 & 68,454 & 1,646 & 50 \\
\hline Percent of total & & 97.58 & 2.35 & 0.07 \\
\hline
\end{tabular}





\section{CONCLUSIONS}

The DOE-NE FCT program conducted a review and technical assessment of the current inventory of domestic discharged UNF to determine if it can be separated into different, distinguishable categories relative to disposition options and, if so, to quantitatively differentiate the UNF inventory relative to the defined categories. The technical assessment considered discharged UNF from commercial nuclear electricity generation and defense and research programs and determined that the current (as of 2011) UNF inventory can be divided into the following three distinguishable categories:

1. Disposal - excess material that is not needed for other purposes;

2. Research - material needed for RD\&D purposes to support waste management (e.g., UNF storage, transportation, and disposal) and development of alternative fuel cycles (e.g., separations and advanced fuels); and

3. Recycle/Recovery - material with inherent and/or strategic value.

The technical assessment subsequently developed a set of key assumptions and attributes relative to the various disposition options and then used the assumptions and attributes to categorize the current UNF inventory. As a result of consideration of RD\&D needs, time frames in which recycle fuel cycles could be realistically implemented, and possible uses to support national security interests, it is estimated that up to 1700 MTHM of existing UNF, including up to 50 MTHM of HEU UNF, should be considered for retention to support RD\&D needs and national security interests. The quantity was determined based on RD\&D needs and practical considerations for access to a representative sample of the diverse commercial UNF inventory to support UNF storage, transportation, and disposal; access to UNF to support fuel cycle technology development; and a sufficient margin to provide assurance that future retrievability from disposal will not be necessary. The assumptions used for this assessment are consistent with the DOE-NE Roadmap; specifically, the time to complete the needed RD\&D places commercial reprocessing availability no sooner than the 2030 time frame. The remainder, $\sim 68,450$ MTHM or $\sim 98 \%$ of the total current inventory by mass, can proceed to permanent disposal without the need to ensure retrievability for reuse or research purposes. This finding does not preclude any decision about alternative fuel cycle options, including those with potential recycling of commercial UNF, since the $\sim 2000$ MTHM that is generated annually could provide the feedstock needed for deployment of alternative fuel cycles.

The main conclusion of this assessment is not the specific amounts or specific assemblies for retention and disposal but rather that access to some small fraction of the existing UNF should be retained, while the remainder can proceed to disposal without the need to ensure retrievability for reuse or research purposes. Because a repository is not anticipated to be available for more than a decade, time is available to refine, if needed, the specific amounts and select specific assemblies as the RD\&D programs proceed and the associated UNF material needs are better defined. 



\section{SUGGESTIONS FOR FURTHER WORK}

During the course of this assessment the following areas for further work were identified.

- Evaluate the issues and potential benefits associated with the recovery of HEU UNF - Although the HEU UNF represents only a small fraction of the current UNF inventory, it could be a valuable resource for a number of applications. Given the special nature of this material, it is recommended that a study be conducted to evaluate the benefits and issues associated with recovering this material.

- Assess the DOE-owned UNF relative to the defined categories - the DOE-owned UNF ( $2500 \mathrm{MTHM})$ is currently designated by DOE-EM for disposal. With the exception of the small fraction that contains HEU, the DOE-owned UNF was not independently assessed here. Given that some of the fuel types in the DOE-owned UNF inventory may have relevance to advanced reactor RD\&D, it may be prudent to reassess the DOE-owned UNF relative to the identified categories..

- Refinement of the specific quantity and specific UNF rods/assemblies for retention of access - the focus of the current work was to determine if the domestic UNF inventory could be separated into different, distinguishable categories relative to disposition options and, if so, to quantitatively differentiate the UNF inventory relative to the defined categories. The result was a set of defined categories and corresponding mass estimates. For this work, it was decided to err on the side of inclusion in the Research category, such that future refinements of the selection criteria and RD\&D needs and/or coordination with industry or a future consolidated storage site to enable access to specific assemblies and/or rods might reduce the variety and amount of material for which access is retained. Therefore, as the RD\&D programs proceed, for example, the Nuclear Fuel Cycle Evaluation and Screening Activity and UFDC activities, it is recommended that further work be performed to refine the specific quantity and specific UNF rods/assemblies for retention of access. 



\section{REFERENCES}

1. U.S. Department of Energy Fuel Cycle Technologies Program, Mission and Objectives, February 2012.

2. Nuclear Energy Research and Development Roadmap, Report to Congress, U.S. Department of Energy, Office of Nuclear Energy, Washington, DC, April 2010, http://www.ne.doe.gov/pdfFiles/NuclearEnergy Roadmap Final.pdf.

3. J. T. Carter, A. J. Luptak, and J. Gastelum, Fuel Cycle Potential Waste Inventory for Disposition, FCR\&D-USED-2010-000031 REV 5, U.S. Department of Energy, July 2012.

4. Commercial Nuclear Waste: Effects of a Termination of the Yucca Mountain Repository Program and Lessons Learned, GAO-11-229, U.S. Government Accountability Office, April 2011.

5. RW-859 Nuclear Fuel Data, Energy Information Administration, Washington, DC, 2004.

6. Spent Nuclear Fuel: Accumulating Quantities at Commercial Reactors Present Storage and Other Challenges, GAO-12-797, U.S. Government Accountability Office, August 2012.

7. Impacts Associated with Transfer of Spent Nuclear Fuel from Spent Fuel Storage Pools to Dry Storage After Five Years of Cooling, 1021049, Electric Power Research Institute, Palo Alto, CA, 2010.

8. D. R. Leduc, Dry Storage of Used Fuel Transition to Transport, FCRD-UFD-2012-000253, Savannah River National Laboratory, Aiken, SC, August 2012.

9. U.S. Nuclear Regulatory Commission website for Combined License Applications of New Reactors, http://www.nrc.gov/reactors/new-reactors/col.html.

10. C. E. Messick, "Foreign Research Reactor Spent Nuclear Fuel Acceptance Program," Proceedings of Technical Meeting, "Return of Research Reactor Spent Fuel to the Country of Origin: Requirements for Technical and Administrative Preparations and National Experiences," pp. 7-11, Vienna, Austria, August 28-31, 2006, http://www-pub.iaea.org/MTCD/publications/PDF/te_1593_web.pdf.

11. Highly Enriched Uranium: Striking a Balance, rev. 1, U.S. Department of Energy, NNSA, January 2001.

12. Gap Analysis to Support Extended Storage of Used Nuclear Fuel, FCRD-USED-2011-000136, REV 0, U.S. Department of Energy, January 2012.

13. UFD Storage and Transportation Working Group Report, FCRD-USED-2011-000323, U.S. Department of Energy, August 2011.

14. U.S. Nuclear Regulatory Commission, Draft Report for Comment, Identification and Prioritization of the Technical Information Needs Affecting Potential Regulation of Extended Storage and Transportation of Spent Nuclear Fuel, May 2012, http://pbadupws.nrc.gov/docs/ML1205/ML120580143.pdf.

15. Extended Storage Collaboration Program (ESCP) Progress Report and Review of Gap Analysis, 1022914, Electric Power Research Institute, Palo Alto, CA, 2011.

16. Evaluation of the Technical Basis for Extended Dry Storage and Transportation of Used Nuclear Fuel - Executive Summary, U.S. Nuclear Waste Technical Review Board, December 2010, http://www.nwtrb.gov/reports/eds_execsumm.pdf.

17. Used Nuclear Fuel Storage and Transportation Research, Development, and Demonstration Plan, FCRD-FCT-2012-000053, REV 0, U.S. Department of Energy, April 2012.

18. W. J. Reich, R. S. Moore, K. J. Notz, Distribution of Characteristics of LWR Spent Fuel, ORNL/TM-1 1670, Oak Ridge National Laboratory, Oak Ridge, TN, January 1991.

19. Interim Staff Guidance 11, rev. 3, Cladding Considerations for the Transportation and Storage of Spent Fuel, SFST-ISG-11, rev. 3, Spent Fuel Project Office, U.S. Nuclear Regulatory Commission, November 17, 2003, http://www.nrc.gov/reading-rm/doc-collections/isg/isg-11R3.pdf.

20. W. J. Bailey, Status of Rod Consolidation, PNL-5122/UC-85, Pacific Northwest Laboratory, April 1985, http://www.osti.gov/bridge/servlets/purl/5807117/5807117.pdf. 
21. Plutonium Fuel: An Assessment Report by an Expert Group, Organisation for Economic Cooperation and Development (OECD), Nuclear Energy Agency (OECD Publications and Information Centre, distributor), Paris, France, 1989.

22. J. Peterson, "Data Mining to Determine Inventory Characteristics of Used Nuclear Fuel for Potential Future Recycling Campaigns," International High-Level Radioactive Waste Management Conference, Albuquerque, NM, April 28-May 2, 2013.

23. Dynamic Systems Analysis Report for Nuclear Fuel Recycle, GNEP-SYSA-AI-SS-RT-2008-000264, May 31, 2008.

24. Annual Energy Outlook 2012 with Projections to 2035, DOE/EIA-0383, U.S. Energy Information Administration, June 2012.

25. A. Worrall, "Utilization of Used Nuclear Fuel (UNF) in a Potential Future US Fuel Cycle Scenario," WM2013, Phoenix, AZ, February 24-28 2013.

26. Nuclear Waste Policy Act of 1982, Section 2, U.S. Senate Committee on Environment and Public Works, 1982, http://epw.senate.gov/envlaws/nwpa82.pdf.

27. Safety Assessment and Feasibility Interim Report 2 (SAFIR 2), ONDRAF/NIRAS, NIROND 200106E, December 2001.

28. Yucca Mountain Repository License Application, DOE/RW-0573, Rev. 1, U.S. Department of Energy (2009).

29. Dossier 2005 Argile, Safety Evaluation of a Geological Repository, Agence nationale pour la gestion des déchets radioactifs (ANDRA), December 2005, http://www.andra.fr/international/download/andra-international-en/document/editions/270va.pdf .

30. Long-term Safety for KBS-3 Repositories at Forsmark and Laxemar - a First Evaluation, Technical Report TR-06-09, SKB [Svensk Kämbränslehantering AB (Swedish Nuclear Fuel and Waste Management Co.)], 2006.

31. Project Opalinus Clay Safety Report: Demonstration of disposal feasibility for spent fuel, vitrified high-level waste and long-lived intermediate-level waste (Entsorgungsnachweis), Technical Report 02-05, NAGRA [Nationale Genossenschaft für die Lagerung Radioactiver Abfälle (National Cooperative for the Disposal of Radioactive Waste)], 2002.

32. U.S. Environmental Protection Agency, "40 CFR 191: Environmental Standards for the Management and Disposal of Spent Nuclear Fuel, High-Level and Transuranic Radioactive Wastes; Final Rule," Federal Register 50, 38082, September 19, 1985.

33. Blue Ribbon Commission on America's Nuclear Future, Report to the Secretary of Energy, p. 31, January 2012, http://brc.gov/sites/default/files/documents/brc finalreport jan2012.pdf.

34. E. A. Schneider, M. R. Deinert, and K. B. Cady, "Cost Analysis of the U.S. Spent Nuclear Fuel Reprocessing Facility," Energy Economics 31, 627-634 (2009).

35. D. E. Shropshire et al., Advanced Fuel Cycle Cost Basis, INL/EXT-07-12107, Idaho National Laboratory, Idaho Falls, ID, 2007.

36. E. Collins et al., "A Practical Approach to a Closed Nuclear Fuel Cycle and Sustained Nuclear Energy," WM2012 Conference, Phoenix, AZ, February 26-March 1, 2012.

37. M. Nutt et al., "Prioritization Criteria for the Selection of Used Nuclear Fuel for Recycling," WM2011 Conference, Phoenix AZ, February 27-March 3, 2011.

38. Shipping and Storage Cask Data for Commercial Spent Nuclear Fuel, JAI-582, JAI Corporation, Fairfax, VA, March 2005.

39. U.S. Department of Energy, Office of Nuclear Energy, Charter for the Evaluation and Screening of Fuel Cycle Options, Washington, DC, December 15, 2011. 
APPENDIX A

COMMERCIAL USED NUCLEAR FUEL CHARACTERISTICS

A-1 


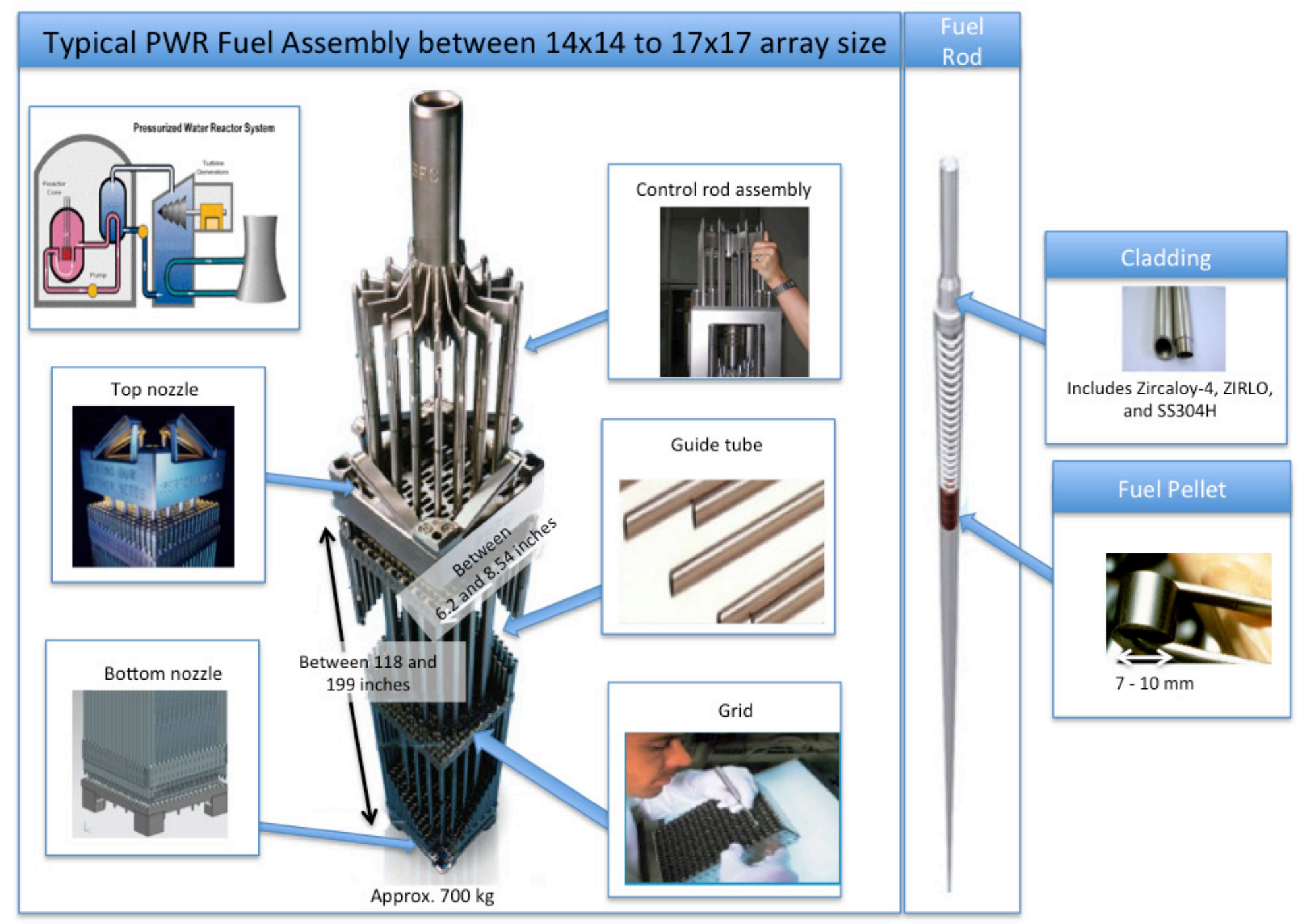

Figure A-1. Typical PWR fuel assembly. 
Table A-1. Physical characteristics of pressurized water reactor assembly classes [Ref. 3]

\begin{tabular}{|c|c|c|c|c|c|c|c|}
\hline $\begin{array}{c}\text { Assembly } \\
\text { class }\end{array}$ & $\begin{array}{c}\text { Array } \\
\text { size }\end{array}$ & Mfr. code & Version & $\begin{array}{c}\text { Assembly } \\
\text { code }\end{array}$ & $\begin{array}{c}\text { Length } \\
\text { (in.) }\end{array}$ & $\begin{array}{c}\text { Width } \\
\text { (in.) }\end{array}$ & $\begin{array}{c}\text { Clad } \\
\text { material }\end{array}$ \\
\hline \multirow[t]{14}{*}{ B\&W $15 \times 15$} & \multirow[t]{14}{*}{$15 \times 15$} & \multirow[t]{13}{*}{$\mathrm{B} \& \mathrm{~W}$} & B\&W Mark B & $\mathrm{B} 1515 \mathrm{~B}$ & 165.7 & 8.54 & Zircaloy-4 \\
\hline & & & B\&W Mark B10 & $\mathrm{B} 1515 \mathrm{~B} 10$ & 165.7 & 8.54 & Zircaloy-4 \\
\hline & & & B\&W Mark B3 & $\mathrm{B} 1515 \mathrm{~B} 3$ & 165.7 & 8.54 & Zircaloy-4 \\
\hline & & & B\&W Mark B4 & $\mathrm{B} 1515 \mathrm{~B} 4$ & 165.7 & 8.54 & Zircaloy-4 \\
\hline & & & B\&W Mark B4Z & $\mathrm{B} 1515 \mathrm{~B} 4 \mathrm{Z}$ & 165.7 & 8.54 & Zircaloy-4 \\
\hline & & & B\&W Mark B5 & B1515B5 & 165.7 & 8.54 & Zircaloy-4 \\
\hline & & & B\&W Mark B5Z & B1515B5Z & 165.7 & 8.54 & Zircaloy-4 \\
\hline & & & B\&W Mark B6 & B1515B6 & 165.7 & 8.54 & Zircaloy-4 \\
\hline & & & B\&W Mark B7 & $\mathrm{B} 1515 \mathrm{~B} 7$ & 165.7 & 8.54 & Zircaloy-4 \\
\hline & & & B\&W Mark B8 & $\mathrm{B} 1515 \mathrm{~B} 8$ & 165.7 & 8.54 & Zircaloy-4 \\
\hline & & & B\&W Mark B9 & B1515B9 & 165.7 & 8.54 & Zircaloy-4 \\
\hline & & & B\&W Mark BGD & B1515BGD & 165.7 & 8.54 & Zircaloy-4 \\
\hline & & & B\&W Mark BZ & $\mathrm{B} 1515 \mathrm{BZ}$ & 165.7 & 8.54 & Zircaloy-4 \\
\hline & & WE & WE & $\mathrm{B} 1515 \mathrm{~W}$ & 165.7 & 8.54 & not available \\
\hline B\&W $17 \times 17$ & $17 \times 17$ & $\mathrm{~B} \& \mathrm{~W}$ & $\mathrm{~B} \& \mathrm{~W}$ Mark C & $\mathrm{B} 1717 \mathrm{~B}$ & 165.7 & 8.54 & Zircaloy-4 \\
\hline \multirow[t]{3}{*}{ CE $14 \times 14$} & \multirow[t]{3}{*}{$14 \times 14$} & ANF & ANF & $\mathrm{C} 1414 \mathrm{~A}$ & 157.0 & 8.10 & Zircaloy-4 \\
\hline & & $\mathrm{CE}$ & $\mathrm{CE}$ & $\mathrm{C} 1414 \mathrm{C}$ & 157.0 & 8.10 & Zircaloy-4 \\
\hline & & WE & WE & $\mathrm{C} 1414 \mathrm{~W}$ & 157.0 & 8.10 & Zircaloy-4 \\
\hline CE $16 \times 16$ & $16 \times 16$ & $\mathrm{CE}$ & $\mathrm{CE}$ & C1616CSD & 176.8 & 8.10 & Zircaloy-4 \\
\hline CE System 80 & $16 \times 16$ & $\mathrm{CE}$ & CE System 80 & $\mathrm{C} 8016 \mathrm{C}$ & 178.3 & 8.10 & Zircaloy-4 \\
\hline \multirow[t]{6}{*}{ WE $14 \times 14$} & \multirow[t]{6}{*}{$14 \times 14$} & ANF & ANF & W1414A & 159.8 & 7.76 & Zircaloy-4 \\
\hline & & ANF & ANF Top Rod & W1414ATR & 159.8 & 7.76 & Zircaloy-4 \\
\hline & & $\mathrm{B} \& \mathrm{~W}$ & $\mathrm{~B} \& \mathrm{~W}$ & W1414B & 159.8 & 7.76 & not available \\
\hline & & WE & WE LOPAR & W1414WL & 159.8 & 7.76 & Zircaloy-4 \\
\hline & & WE & WE OFA & W1414WO & 159.8 & 7.76 & Zircaloy-4 \\
\hline & & WE & WE Std & W1414W & 159.8 & 7.76 & Zircaloy-4 \\
\hline \multirow[t]{7}{*}{ WE $15 \times 15$} & \multirow[t]{7}{*}{$15 \times 15$} & \multirow[t]{3}{*}{ ANF } & ANF & $\mathrm{W} 1515 \mathrm{~A}$ & 159.8 & 8.44 & Zircaloy-4 \\
\hline & & & ANF HT & W1515AHT & 159.8 & 8.44 & not available \\
\hline & & & ANF Part Length & W1515APL & 159.8 & 8.44 & not available \\
\hline & & \multirow[t]{4}{*}{ WE } & LOPAR & W1515WL & 159.8 & 8.44 & Zircaloy-4 \\
\hline & & & OFA & W1515WO & 159.8 & 8.44 & Zircaloy-4 \\
\hline & & & WE Std & W1515W & 159.8 & 8.44 & Zircaloy \\
\hline & & & WE Vantage 5 & W1515WV5 & 159.8 & 8.44 & not available \\
\hline
\end{tabular}


Table A-1 (continued)

\begin{tabular}{|c|c|c|c|c|c|c|c|}
\hline $\begin{array}{c}\text { Assembly } \\
\text { class }\end{array}$ & $\begin{array}{c}\text { Array } \\
\text { size }\end{array}$ & Mfr. code & Version & $\begin{array}{c}\text { Assembly } \\
\text { code }\end{array}$ & $\begin{array}{l}\text { Length } \\
\text { (in.) }\end{array}$ & $\begin{array}{c}\text { Width } \\
\text { (in.) }\end{array}$ & $\begin{array}{c}\text { Clad } \\
\text { material }\end{array}$ \\
\hline \multirow[t]{11}{*}{ WE $17 \times 17$} & \multirow[t]{11}{*}{$17 \times 17$} & ANF & ANF & W1717A & 159.8 & 8.44 & Zircaloy-4 \\
\hline & & $\mathrm{B} \& \mathrm{~W}$ & B\&W Mark B & W1717B & 159.8 & 8.44 & not available \\
\hline & & \multirow[t]{9}{*}{ WE } & WE & W1717WRF & 159.8 & 8.44 & not available \\
\hline & & & WE & W1717WVJ & 159.8 & 8.44 & not available \\
\hline & & & WE LOPAR & W1717WL & 159.8 & 8.44 & Zircaloy-4 \\
\hline & & & WE OFA & W1717WO & 159.8 & 8.44 & Zircaloy-4 \\
\hline & & & WE Pressurized & W1717WP & 159.8 & 8.44 & not available \\
\hline & & & WE Vantage & W1717WV & 159.8 & 8.44 & not available \\
\hline & & & WE Vantage + & W1717WV+ & 159.8 & 8.44 & ZIRLO \\
\hline & & & WE Vantage 5 & W1717WV5 & 159.8 & 8.44 & Zircaloy-4 \\
\hline & & & WE Vantage $5 \mathrm{H}$ & W1717WVH & 159.8 & 8.44 & not available \\
\hline South Texas & $17 \times 17$ & WE & WE & WST17W & 199.0 & 8.43 & Zircaloy-4 \\
\hline \multirow[t]{3}{*}{ Ft. Calhoun } & \multirow[t]{3}{*}{$14 \times 14$} & ANF & ANF & XFC14A & 146.0 & 8.10 & not available \\
\hline & & $\mathrm{CE}$ & $\mathrm{CE}$ & $\mathrm{XFC14C}$ & 146.0 & 8.10 & Zircaloy-4 \\
\hline & & WE & WE & $\mathrm{XFC14W}$ & 146.0 & 8.10 & not available \\
\hline \multirow[t]{8}{*}{ Haddam Neck } & \multirow[t]{8}{*}{$15 \times 15$} & \multirow[t]{2}{*}{$\mathrm{B} \& \mathrm{~W}$} & B\&W SS & XHN15B & 137.1 & 8.42 & SS-304 \\
\hline & & & B\&W Zir & XHN15BZ & 137.1 & 8.42 & Zircaloy \\
\hline & & \multirow[t]{2}{*}{ GA } & Gulf SS & XHN15HS & 137.1 & 8.42 & $\mathrm{SS}$ \\
\hline & & & Gulf Zir & XHN15HZ & 137.1 & 8.42 & Zircaloy \\
\hline & & \multirow[t]{2}{*}{ NU } & NUM SS & XHN15MS & 137.1 & 8.42 & $\mathrm{SS}$ \\
\hline & & & NUM Zir & XHN15MZ & 137.1 & 8.42 & Zircaloy \\
\hline & & \multirow[t]{2}{*}{ WE } & WE & XHN15W & 137.1 & 8.42 & SS-304 \\
\hline & & & WE Zir & XHN15WZ & 137.1 & 8.42 & not available \\
\hline Indian Point-1 & $13 \times 14$ & WE & WE & XIP14W & 138.8 & 6.27 & SS \\
\hline \multirow[t]{2}{*}{ Palisades } & \multirow[t]{2}{*}{$15 \times 15$} & ANF & ANF & XPA15A & 147.5 & 8.20 & Zircaloy-4 \\
\hline & & $\mathrm{CE}$ & $\mathrm{CE}$ & XPA15C & 147.5 & 8.20 & Zircaloy-4 \\
\hline St. Lucie-2 & $16 \times 16$ & $\mathrm{CE}$ & $\mathrm{CE}$ & XSL16C & 158.2 & 8.10 & Zircaloy-4 \\
\hline \multirow[t]{3}{*}{ San Onofre-1 } & \multirow[t]{3}{*}{$14 \times 14$} & \multirow[t]{3}{*}{ WE } & WE & XSO14W & 137.1 & 7.76 & SS-304 \\
\hline & & & WE D & XSO14WD & 137.1 & 7.76 & not available \\
\hline & & & WE M & XSO14WM & 137.1 & 7.76 & not available \\
\hline \multirow[t]{4}{*}{ Yankee Rowe } & \multirow[t]{3}{*}{$15 \times 16$} & ANF & ANF & XYR16A & 111.8 & 7.62 & Zircaloy-4 \\
\hline & & $\mathrm{CE}$ & $\mathrm{CE}$ & XYR16C & 111.8 & 7.62 & Zircaloy-4 \\
\hline & & UNC & UNC & XYR16U & 111.8 & 7.62 & not available \\
\hline & $17 \times 18$ & WE & WE & XYR18W & 111.8 & 7.62 & SS \\
\hline
\end{tabular}

Note: some characteristics of more recently discharged UNF (post-1999) have not yet been provided. 

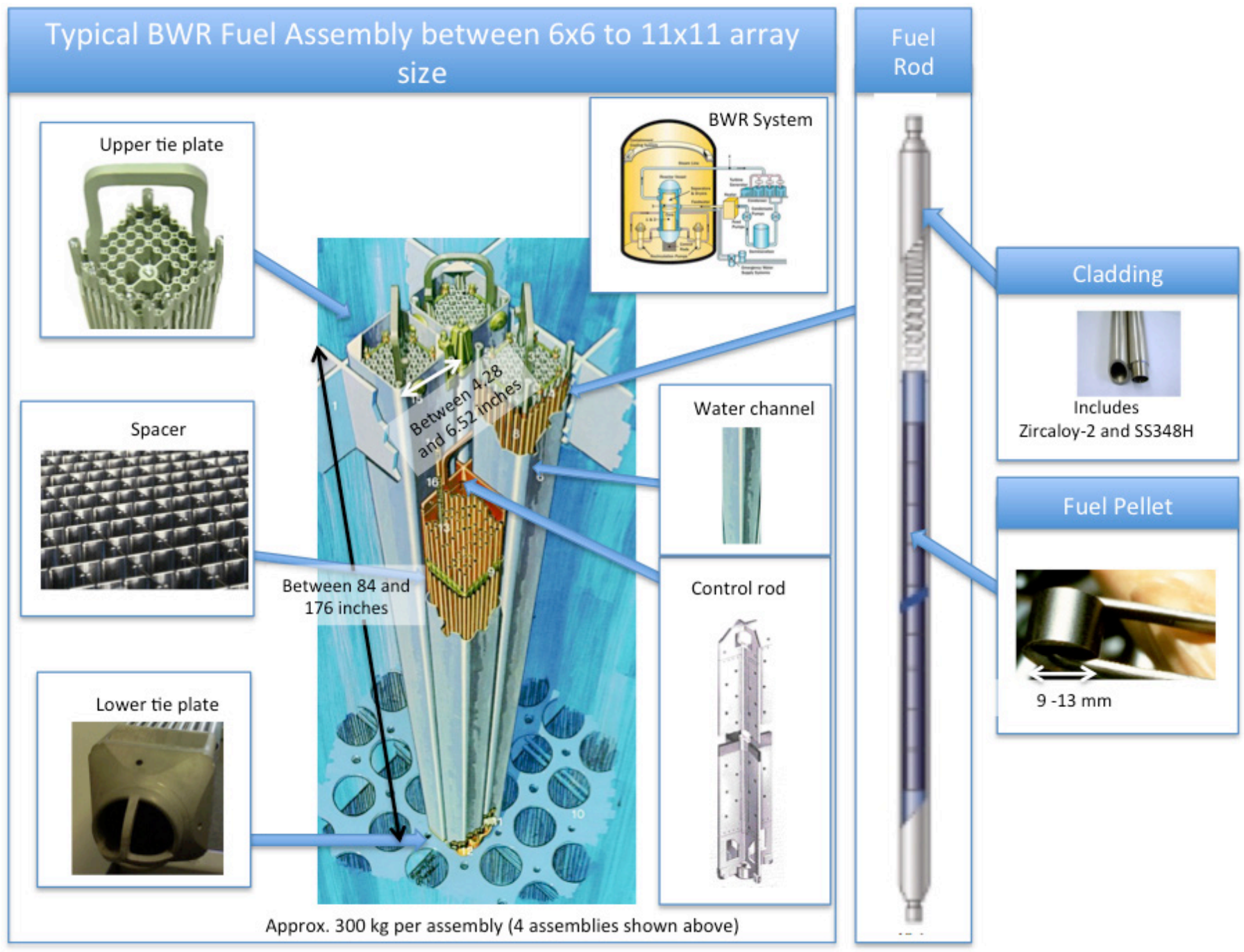

Figure A-2. Typical BWR fuel assembly. 
Table A-2. Physical characteristics of boiling water reactor assembly classes [Ref 3]

\begin{tabular}{|c|c|c|c|c|c|c|c|}
\hline $\begin{array}{c}\text { Assembly } \\
\text { class }\end{array}$ & $\begin{array}{c}\text { Array } \\
\text { size }\end{array}$ & Mfr. code & Version & $\begin{array}{c}\text { Assembly } \\
\text { code }\end{array}$ & $\begin{array}{l}\text { Length } \\
\text { (in.) }\end{array}$ & $\begin{array}{c}\text { Width } \\
\text { (in.) }\end{array}$ & $\begin{array}{c}\text { Clad } \\
\text { material }\end{array}$ \\
\hline \multirow{19}{*}{$\begin{array}{l}\text { GE BWR/ } \\
2,3\end{array}$} & $7 \times 7$ & ANF & ANF & G2307A & 171.2 & 5.44 & Zircaloy-2 \\
\hline & $8 \times 8$ & ANF & ANF & G2308A & 171.2 & 5.44 & Zircaloy-2 \\
\hline & \multirow[t]{2}{*}{$9 \times 9$} & \multirow[t]{2}{*}{ ANF } & ANF & G2309A & 171.2 & 5.44 & Zircaloy-2 \\
\hline & & & ANF IX & G2309AIX & 171.2 & 5.44 & Zircaloy-2 \\
\hline & \multirow[t]{2}{*}{$8 \times 8$} & ANF & $\begin{array}{l}\text { ANF } \\
\text { Pressurized }\end{array}$ & G2308AP & 171.2 & 5.44 & Zircaloy-2 \\
\hline & & GE & GE-10 & G2308G10 & 171.2 & 5.44 & Zircaloy-2 \\
\hline & $9 \times 9$ & GE & GE-11 & G2309G11 & 171.2 & 5.44 & Zircaloy-2 \\
\hline & \multirow[t]{3}{*}{$7 \times 7$} & \multirow[t]{3}{*}{ GE } & GE-2a & $\mathrm{G} 2307 \mathrm{G} 2 \mathrm{~A}$ & 171.2 & 5.44 & Zircaloy-2 \\
\hline & & & GE-2b & $\mathrm{G} 2307 \mathrm{G} 2 \mathrm{~B}$ & 171.2 & 5.44 & Zircaloy-2 \\
\hline & & & GE-3 & G2307G3 & 171.2 & 5.44 & Zircaloy-2 \\
\hline & \multirow[t]{8}{*}{$8 \times 8$} & \multirow[t]{8}{*}{ GE } & GE-4 & G2308G4 & 171.2 & 5.44 & Zircaloy-2 \\
\hline & & & GE-5 & G2308G5 & 171.2 & 5.44 & Zircaloy-2 \\
\hline & & & GE-7 & G2308G7 & 171.2 & 5.44 & NA \\
\hline & & & GE-8a & G2308G8A & 171.2 & 5.44 & Zircaloy-2 \\
\hline & & & GE- $8 b$ & G2308G8B & 171.2 & 5.44 & Zircaloy-2 \\
\hline & & & GE-9 & G2308G9 & 171.2 & 5.44 & Zircaloy-2 \\
\hline & & & GE-Barrier & G2308GB & 171.2 & 5.44 & Zircaloy-2 \\
\hline & & & GE-Pressurized & G2308GP & 171.2 & 5.44 & Zircaloy-2 \\
\hline & NA & NA & NA & 9X9IXQFA & 171.2 & 5.44 & NA \\
\hline \multirow{9}{*}{$\begin{array}{l}\text { GE BWR/ } \\
4-6\end{array}$} & $9 \times 9$ & ANF & ANF & G4609A & 176.2 & 5.44 & Zircaloy-2 \\
\hline & $10 \times 10$ & ANF & ANF & G4610A & 176.2 & 5.44 & NA \\
\hline & \multirow[t]{3}{*}{$9 \times 9$} & \multirow[t]{3}{*}{ ANF } & ANF 9-5 & G4609A5 & 176.2 & 5.44 & Zircaloy-2 \\
\hline & & & ANF 9X & G4609A9X & 176.2 & 5.44 & Zircaloy-2 \\
\hline & & & ANF IX & G4609AIX & 176.2 & 5.44 & Zircaloy-2 \\
\hline & $10 \times 10$ & ANF & ANF IX & G4610AIX & 176.2 & 5.44 & NA \\
\hline & $9 \times 9$ & ANF & ANF $X^{+}$ & G4609AX+ & 176.2 & 5.44 & NA \\
\hline & $8 \times 8$ & ANF & $\begin{array}{l}\text { ANF- } \\
\text { Pressurized }\end{array}$ & G4608AP & 176.2 & 5.44 & Zircaloy-2 \\
\hline & NA & AREVA & NA & ATRIUM10 & 176.2 & 5.44 & Zircaloy-2 ${ }^{\mathrm{a}}$ \\
\hline
\end{tabular}


Table A-2 (continued)

\begin{tabular}{|c|c|c|c|c|c|c|c|}
\hline $\begin{array}{c}\text { Assembly } \\
\text { class }\end{array}$ & $\begin{array}{c}\text { Array } \\
\text { size }\end{array}$ & Mfr. code & Version & $\begin{array}{c}\text { Assembly } \\
\text { code }\end{array}$ & $\begin{array}{c}\text { Length } \\
\text { (in.) }\end{array}$ & $\begin{array}{c}\text { Width } \\
\text { (in.) }\end{array}$ & $\begin{array}{c}\text { Clad } \\
\text { material }\end{array}$ \\
\hline \multirow{19}{*}{$\begin{array}{l}\text { GE BWR/ } \\
4-6 \\
\text { (Continued) }\end{array}$} & $10 \times 10$ & $\mathrm{ABB}$ & $\mathrm{CE}$ & G4610C & 176.2 & 5.44 & NA \\
\hline & \multirow[t]{2}{*}{$8 \times 8$} & \multirow[t]{2}{*}{ GE } & GE-10 & G4608G10 & 176.2 & 5.44 & Zircaloy-2 \\
\hline & & & GE-11 & G4608G11 & 176.2 & 5.44 & NA \\
\hline & $9 \times 9$ & GE & GE-11 & G4609G11 & 176.2 & 5.44 & Zircaloy-2 \\
\hline & $8 \times 8$ & GE & GE-12 & G4608G12 & 176.2 & 5.44 & NA \\
\hline & $10 \times 10$ & GE & GE-12 & G4610G12 & 176.2 & 5.44 & Zircaloy-2 \\
\hline & $9 \times 9$ & GE & GE-13 & G4609G13 & 176.2 & 5.44 & Zircaloy-2 \\
\hline & $10 \times 10$ & GE & GE-14 & G4610G14 & 176.2 & 5.44 & NA \\
\hline & \multirow[t]{3}{*}{$7 \times 7$} & \multirow[t]{3}{*}{ GE } & GE-2 & G4607G2 & 176.2 & 5.44 & Zircaloy-2 \\
\hline & & & GE-3a & G4607G3A & 176.2 & 5.44 & Zircaloy-2 \\
\hline & & & GE-3b & G4607G3B & 176.2 & 5.44 & Zircaloy-2 \\
\hline & \multirow[t]{8}{*}{$8 \times 8$} & \multirow[t]{7}{*}{ GE } & GE-4a & G4608G4A & 176.2 & 5.44 & Zircaloy-2 \\
\hline & & & GE-4b & G4608G4B & 176.2 & 5.44 & Zircaloy-2 \\
\hline & & & GE-5 & G4608G5 & 176.2 & 5.44 & Zircaloy-2 \\
\hline & & & GE-8 & G4608G8 & 176.2 & 5.44 & Zircaloy-2 \\
\hline & & & GE-9 & G4608G9 & 176.2 & 5.44 & Zircaloy-2 \\
\hline & & & GE-Barrier & G4608GB & 176.2 & 5.44 & Zircaloy-2 \\
\hline & & & GE-Pressurized & G4608GP & 176.2 & 5.44 & Zircaloy-2 \\
\hline & & WE & WE & G4608W & 176.2 & 5.44 & Zircaloy-2 \\
\hline \multirow{7}{*}{$\begin{array}{l}\text { Big Rock } \\
\text { Point }\end{array}$} & $9 \times 9$ & ANF & ANF & XBR09A & 84 & 6.52 & Zircaloy-2 \\
\hline & $11 \times 11$ & ANF & ANF & XBR11A & 84 & 6.52 & Zircaloy-2 \\
\hline & $7 \times 7$ & GE & GE & XBR07G & 84 & 6.52 & NA \\
\hline & $8 \times 8$ & GE & GE & XBR08G & 84 & 6.52 & NA \\
\hline & $9 \times 9$ & GE & GE & XBR09G & 84 & 6.52 & Zircaloy-2 \\
\hline & \multirow[t]{2}{*}{$11 \times 11$} & GE & GE & XBR11G & 84 & 6.52 & Zircaloy-2 \\
\hline & & NFS & NFS & XBR11N & 84 & 6.52 & NA \\
\hline \multirow[t]{8}{*}{ Dresden-1 } & \multirow[t]{2}{*}{$6 \times 6$} & ANF & ANF & XDR06A & 134.4 & 4.28 & Zircaloy-2 \\
\hline & & GE & GE & XDR06G & 134.4 & 4.28 & Zircaloy-2 \\
\hline & $7 \times 7$ & GE & GE SA-1 & XDR07GS & 134.4 & 4.28 & NA \\
\hline & $8 \times 8$ & GE & GE PF Fuels & XDR08G & 134.4 & 4.28 & NA \\
\hline & \multirow[t]{4}{*}{$6 \times 6$} & \multirow[t]{3}{*}{ GE } & GE Type III-B & XDR06G3B & 134.4 & 4.28 & NA \\
\hline & & & GE Type III-F & XDR06G3F & 134.4 & 4.28 & NA \\
\hline & & & GE Type V & XDR06G5 & 134.4 & 4.28 & NA \\
\hline & & UNC & UNC & XDR06U & 134.4 & 4.28 & NA \\
\hline
\end{tabular}


Table A-2 (continued)

\begin{tabular}{|l|c|l|l|l|c|c|l|}
\hline $\begin{array}{c}\text { Assembly } \\
\text { class }\end{array}$ & $\begin{array}{c}\text { Array } \\
\text { size }\end{array}$ & \multicolumn{1}{|c|}{ Mfr. code } & \multicolumn{1}{|c|}{ Version } & $\begin{array}{c}\text { Assembly } \\
\text { code }\end{array}$ & $\begin{array}{c}\text { Length } \\
\text { (in.) }\end{array}$ & $\begin{array}{c}\text { Width } \\
\text { (in.) }\end{array}$ & $\begin{array}{c}\text { Clad } \\
\text { material }\end{array}$ \\
\hline \multirow{2}{*}{$\begin{array}{l}\text { Humboldt } \\
\text { Bay }\end{array}$} & $6 \times 6$ & ANF & $6 \times 6$ ANF & XHB06A & 95 & 4.67 & Zircaloy \\
\cline { 2 - 8 } & & GE & GE & XHB06G & 95 & 4.67 & Zircaloy-2 \\
\cline { 2 - 8 } & $7 \times 7$ & GE & GE Type II & XHB07G2 & 95 & 4.67 & Zircaloy \\
\hline \multirow{2}{*}{ La Crosse } & $10 \times 10$ & AC & AC & XLC10L & 102.5 & 5.62 & SS348H \\
\cline { 3 - 8 } & & ANF & ANF & XLC10A & 102.5 & 5.62 & SS348H \\
\hline
\end{tabular}

Note: some characteristics of more recently discharged UNF (post-1999) have not yet been provided. 
Table A-3. Assembly types and their main characteristics as of December 31, 2002 [Ref. 3]

\begin{tabular}{|c|c|c|c|c|c|c|c|c|c|}
\hline \multirow{2}{*}{$\begin{array}{c}\text { Reactor } \\
\text { type }\end{array}$} & \multirow{2}{*}{$\begin{array}{c}\text { Manufacturer } \\
\text { code }\end{array}$} & \multirow{2}{*}{$\begin{array}{c}\text { Assembly } \\
\text { code }\end{array}$} & \multicolumn{2}{|c|}{$\begin{array}{c}\text { Initial uranium } \\
\text { loading } \\
\text { (kg/assembly) }\end{array}$} & \multicolumn{3}{|c|}{$\begin{array}{l}\text { Enrichment } \\
\left(\mathbf{U}^{235} \text { wt \%) }\right.\end{array}$} & \multicolumn{2}{|c|}{$\begin{array}{c}\text { Burnup } \\
\text { (MWd/MTU) }\end{array}$} \\
\hline & & & Avg. & Max. & Min. & Avg. & Max. & Avg. & Max. \\
\hline BWR & not available & 9X9IXQFA & 170.713 & 170.800 & 3.25 & 3.25 & 3.25 & 39,166 & 39,248 \\
\hline BWR & $\mathrm{AC}$ & XLC10L & 120.160 & 121.034 & 3.63 & 3.77 & 3.94 & 14,419 & 21,532 \\
\hline BWR & ANF & G2307A & 181.574 & 183.797 & 2.56 & 2.64 & 2.65 & 24,256 & 27,826 \\
\hline BWR & ANF & G2308A & 174.624 & 184.355 & 2.39 & 2.66 & 3.13 & 28,814 & 36,826 \\
\hline BWR & ANF & G2308AP & 172.753 & 173.132 & 2.82 & 2.83 & 2.83 & 34,366 & 34,826 \\
\hline BWR & ANF & G2309A & 168.097 & 169.520 & 2.78 & 3.10 & 3.15 & 35,941 & 40,818 \\
\hline BWR & ANF & G2309AIX & 169.185 & 170.059 & 3.25 & 3.31 & 3.82 & 39,151 & 43,778 \\
\hline BWR & ANF & G4608AP & 176.175 & 176.800 & 2.62 & 2.88 & 3.40 & 31,248 & 35,518 \\
\hline BWR & ANF & G4609A & 172.970 & 174.700 & 0.72 & 3.42 & 3.73 & 36,933 & 47,000 \\
\hline BWR & ANF & G4609A5 & 176.147 & 177.000 & 2.90 & 3.28 & 3.55 & 36,536 & 43,555 \\
\hline BWR & ANF & G4609A9X & 169.155 & 176.800 & 2.53 & 2.87 & 3.11 & 36,880 & 43,330 \\
\hline BWR & ANF & G4609AIX & 174.788 & 177.000 & 3.00 & 3.58 & 3.94 & 24,156 & 36,777 \\
\hline BWR & ANF & G4609AX+ & 167.264 & 167.277 & 3.13 & 3.14 & 3.15 & 39,239 & 40,457 \\
\hline BWR & ANF & G4610A & 176.900 & 176.900 & 3.94 & 3.94 & 3.94 & 38,207 & 39,000 \\
\hline BWR & ANF & G4610AIX & 175.000 & 175.000 & 3.39 & 3.39 & 3.39 & 37,706 & 38,009 \\
\hline BWR & ANF & XBR09A & 127.687 & 131.406 & 3.45 & 3.48 & 3.52 & 20,981 & 22,811 \\
\hline BWR & ANF & XBR11A & 130.237 & 133.174 & 3.13 & 3.42 & 3.82 & 22,716 & 34,212 \\
\hline BWR & ANF & XDR06A & 95.206 & 95.478 & 2.23 & 2.23 & 2.24 & 4,907 & 5,742 \\
\hline BWR & ANF & XHB06A & 69.734 & 73.800 & 2.35 & 2.40 & 2.41 & 9,037 & 22,377 \\
\hline BWR & ANF & XLC10A & 108.657 & 109.609 & 3.68 & 3.69 & 3.71 & 15,017 & 20,126 \\
\hline BWR & AREVA & ATRIUM10 & 176.900 & 176.900 & 3.94 & 3.94 & 3.94 & 38,406 & 39,000 \\
\hline BWR & $\mathrm{ABB}$ & G4610C & 175.683 & 176.300 & 2.51 & 3.29 & 3.62 & 38,133 & 42,640 \\
\hline BWR & GE & G2307G2A & 194.902 & 197.604 & 2.07 & 2.10 & 2.11 & 16,775 & 24,902 \\
\hline BWR & GE & G2307G2B & 193.203 & 197.400 & 1.65 & 2.15 & 2.62 & 16,384 & 29,728 \\
\hline BWR & GE & G2307G3 & 187.419 & 189.105 & 1.96 & 2.41 & 2.60 & 25,420 & 38,861 \\
\hline BWR & GE & G2308G10 & 172.225 & 173.512 & 3.10 & 3.25 & 3.56 & 33,988 & 43,977 \\
\hline BWR & GE & G2308G4 & 183.991 & 185.496 & 2.19 & 2.51 & 2.76 & 26,087 & 40,523 \\
\hline BWR & GE & G2308G5 & 176.971 & 177.628 & 2.39 & 2.66 & 2.82 & 29,009 & 33,597 \\
\hline BWR & GE & G2308G7 & 178.520 & 179.400 & 2.96 & 2.97 & 2.99 & 31,570 & 35,894 \\
\hline BWR & GE & G2308G8A & 175.695 & 179.584 & 2.55 & 3.09 & 3.40 & 34,848 & 44,933 \\
\hline BWR & GE & G2308G8B & 172.590 & 178.000 & 2.96 & 3.19 & 3.39 & 36,400 & 42,518 \\
\hline BWR & GE & G2308G9 & 172.017 & 173.108 & 2.85 & 3.18 & 3.48 & 37,268 & 42,295 \\
\hline BWR & GE & G2308GB & 177.983 & 180.060 & 2.62 & 2.80 & 3.39 & 32,014 & 43,381 \\
\hline BWR & GE & G2308GP & 177.145 & 179.200 & 2.08 & 2.77 & 3.01 & 29,317 & 38,139 \\
\hline
\end{tabular}


Table A-3 (continued)

\begin{tabular}{|c|c|c|c|c|c|c|c|c|c|}
\hline \multirow{2}{*}{$\begin{array}{c}\text { Reactor } \\
\text { type }\end{array}$} & \multirow{2}{*}{$\begin{array}{c}\text { Manufacturer } \\
\text { code }\end{array}$} & \multirow{2}{*}{$\begin{array}{c}\text { Assembly } \\
\text { code }\end{array}$} & \multicolumn{2}{|c|}{$\begin{array}{c}\text { Initial uranium } \\
\text { loading } \\
\text { (kg/assembly) }\end{array}$} & \multicolumn{3}{|c|}{$\begin{array}{l}\text { Enrichment } \\
\left(\mathrm{U}^{235} \text { wt \%) }\right.\end{array}$} & \multicolumn{2}{|c|}{$\begin{array}{c}\text { Burnup } \\
\text { (MWd/MTU) }\end{array}$} \\
\hline & & & Avg. & Max. & Min. & Avg. & Max. & Avg. & Max. \\
\hline BWR & GE & G2309G11 & 165.650 & 169.500 & 3.10 & 3.56 & 3.78 & 40,522 & 45,117 \\
\hline BWR & GE & G4607G2 & 194.729 & 197.334 & 1.09 & 1.56 & 2.50 & 9,362 & 11,829 \\
\hline BWR & GE & G4607G3A & 187.455 & 189.141 & 1.10 & 2.33 & 2.51 & 21,058 & 32,188 \\
\hline BWR & GE & G4607G3B & 189.925 & 191.542 & 1.10 & 2.31 & 2.51 & 21,948 & 30,831 \\
\hline BWR & GE & G4608G10 & 177.778 & 186.094 & 2.63 & 3.24 & 3.70 & 36,695 & 44,343 \\
\hline BWR & GE & G4608G11 & 170.786 & 171.000 & 3.38 & 3.38 & 3.38 & 35,194 & 42,551 \\
\hline BWR & GE & G4608G12 & 180.873 & 181.484 & 3.69 & 3.71 & 3.99 & 32,069 & 34,462 \\
\hline BWR & GE & G4608G4A & 183.931 & 185.221 & 2.19 & 2.62 & 2.99 & 24,931 & 43,430 \\
\hline BWR & GE & G4608G4B & 186.709 & 187.900 & 2.10 & 2.31 & 2.76 & 21,362 & 32,941 \\
\hline BWR & GE & G4608G5 & 183.007 & 185.366 & 0.70 & 2.36 & 3.01 & 23,964 & 38,224 \\
\hline BWR & GE & G4608G8 & 179.801 & 185.854 & 2.95 & 3.19 & 3.40 & 34,905 & 44,640 \\
\hline BWR & GE & G4608G8B & 178.000 & 178.000 & 3.36 & 3.37 & 3.39 & 35,174 & 38,396 \\
\hline BWR & GE & G4608G9 & 177.738 & 185.789 & 1.51 & 3.23 & 3.88 & 36,492 & 47,062 \\
\hline BWR & GE & G4608GB & 184.636 & 186.653 & 0.71 & 2.53 & 3.25 & 26,297 & 45,986 \\
\hline BWR & GE & G4608GP & 183.195 & 186.888 & 0.70 & 2.38 & 3.27 & 23,112 & 42,428 \\
\hline BWR & GE & G4609G11 & 170.123 & 178.136 & 1.46 & 3.56 & 4.14 & 40,351 & 65,149 \\
\hline BWR & GE & G4609G13 & 171.417 & 172.912 & 3.24 & 3.85 & 4.17 & 42,045 & 53,636 \\
\hline BWR & GE & G4610G12 & 176.100 & 182.141 & 3.12 & 3.98 & 4.20 & 44,175 & 52,735 \\
\hline BWR & GE & G4610G14 & 179.127 & 180.402 & 4.01 & 4.11 & 4.24 & 5,868 & 8,915 \\
\hline BWR & GE & G4806G10 & 178.400 & 178.400 & 3.06 & 3.06 & 3.06 & 34,473 & 36,591 \\
\hline BWR & GE & XBR07G & 131.500 & 133.000 & 2.88 & 2.88 & 2.88 & 1,643 & 1,690 \\
\hline BWR & GE & XBR08G & 112.500 & 113.000 & 2.85 & 2.85 & 2.85 & 4,546 & 7,027 \\
\hline BWR & GE & XBR09G & 137.088 & 141.000 & 3.51 & 3.58 & 3.62 & 15,092 & 22,083 \\
\hline BWR & GE & XBR11G & 124.500 & 132.000 & 3.11 & 3.46 & 3.63 & 22,802 & 24,997 \\
\hline BWR & GE & XDR06G & 111.352 & 111.352 & 1.47 & 1.47 & 1.47 & 23,522 & 23,522 \\
\hline BWR & GE & XDR06G3B & 101.610 & 102.520 & 1.83 & 1.83 & 1.83 & 18,632 & 27,106 \\
\hline BWR & GE & XDR06G3F & 102.049 & 102.876 & 2.25 & 2.25 & 2.25 & 22,132 & 28,138 \\
\hline BWR & GE & XDR06G5 & 105.857 & 112.257 & 2.26 & 2.26 & 2.26 & 21,095 & 25,886 \\
\hline BWR & GE & XDR07GS & 59.000 & 59.000 & 3.10 & 3.10 & 3.10 & 29,000 & 29,000 \\
\hline BWR & GE & XDR08G & 99.714 & 99.714 & 1.95 & 1.95 & 1.95 & 25,287 & 25,287 \\
\hline BWR & GE & XHB06G & 76.355 & 77.000 & 2.35 & 2.43 & 2.52 & 17,170 & 22,876 \\
\hline BWR & GE & XHB07G2 & 76.325 & 77.100 & 2.08 & 2.11 & 2.31 & 18,187 & 20,770 \\
\hline BWR & NFS & XBR11N & 128.991 & 134.414 & 2.16 & 2.83 & 3.51 & 18,940 & 21,850 \\
\hline BWR & UNC & XDR06U & 102.021 & 103.441 & 1.83 & 2.24 & 2.26 & 17,685 & 26,396 \\
\hline BWR & WE & G4608W & 156.696 & 171.403 & 2.69 & 2.85 & 3.01 & 28,041 & 33,140 \\
\hline
\end{tabular}


Table A-3 (continued)

\begin{tabular}{|c|c|c|c|c|c|c|c|c|c|}
\hline \multirow{2}{*}{$\begin{array}{c}\text { Reactor } \\
\text { type }\end{array}$} & \multirow{2}{*}{$\begin{array}{c}\text { Manufacturer } \\
\text { code }\end{array}$} & \multirow{2}{*}{$\begin{array}{c}\text { Assembly } \\
\text { code }\end{array}$} & \multicolumn{2}{|c|}{$\begin{array}{c}\text { Initial uranium } \\
\text { loading } \\
\text { (kg/assembly) }\end{array}$} & \multicolumn{3}{|c|}{$\begin{array}{l}\text { Enrichment } \\
\left(\mathbf{U}^{235} w t \%\right)\end{array}$} & \multicolumn{2}{|c|}{$\begin{array}{c}\text { Burnup } \\
\text { (MWd/MTU) }\end{array}$} \\
\hline & & & Avg. & Max. & Min. & Avg. & Max. & Avg. & Max. \\
\hline PWR & ANF & C1414A & 380.870 & 400.000 & 0.30 & 3.50 & 4.32 & 38,899 & 50,871 \\
\hline PWR & ANF & W1414A & 378.274 & 406.840 & 0.71 & 3.42 & 4.50 & 37,500 & 56,328 \\
\hline PWR & ANF & W1414ATR & 362.788 & 368.011 & 2.39 & 3.38 & 3.57 & 38,168 & 46,000 \\
\hline PWR & ANF & W1515A & 428.888 & 434.792 & 2.01 & 3.00 & 3.60 & 33,344 & 49,859 \\
\hline PWR & ANF & W1515AHT & 434.546 & 438.074 & 3.51 & 4.08 & 4.59 & 45,441 & 56,922 \\
\hline PWR & ANF & W1515APL & 307.361 & 310.073 & 1.23 & 1.55 & 1.88 & 27,971 & 37,770 \\
\hline PWR & ANF & W1717A & 413.845 & 460.540 & 2.43 & 4.19 & 4.77 & 45,291 & 53,958 \\
\hline PWR & ANF & XFC14A & 353.345 & 358.811 & 3.50 & 3.57 & 3.80 & 37,205 & 46,048 \\
\hline PWR & ANF & XPA15A & 396.674 & 408.040 & 1.50 & 3.17 & 4.05 & 34,362 & 51,486 \\
\hline PWR & ANF & XYR16A & 233.555 & 237.300 & 3.49 & 3.78 & 4.02 & 29,034 & 35,088 \\
\hline PWR & $\mathrm{B} \& \mathrm{~W}$ & $\mathrm{~B} 1515 \mathrm{~B}$ & 463.398 & 465.480 & 2.74 & 3.57 & 3.62 & 40,407 & 50,128 \\
\hline PWR & $\mathrm{B} \& W$ & B1515B10 & 476.778 & 489.299 & 3.24 & 3.90 & 4.73 & 44,417 & 56,880 \\
\hline PWR & $\mathrm{B} \& \mathrm{~W}$ & B1515B3 & 463.845 & 465.830 & 1.08 & 2.42 & 2.84 & 21,036 & 32,267 \\
\hline PWR & $\mathrm{B} \& \mathrm{~W}$ & B1515B4 & 464.285 & 474.853 & 0.90 & 2.91 & 4.06 & 29,534 & 57,000 \\
\hline PWR & $\mathrm{B} \& \mathrm{~W}$ & B1515B4Z & 463.735 & 466.305 & 3.22 & 3.84 & 3.95 & 39,253 & 51,660 \\
\hline PWR & $\mathrm{B} \& W$ & B1515B5 & 468.250 & 468.250 & 3.13 & 3.13 & 3.13 & 38,017 & 39,000 \\
\hline PWR & $\mathrm{B} \& \mathrm{~W}$ & B1515B5Z & 464.421 & 465.176 & 3.20 & 3.22 & 3.23 & 36,016 & 42,328 \\
\hline PWR & $\mathrm{B} \& \mathrm{~W}$ & B1515B6 & 462.495 & 464.403 & 3.22 & 3.47 & 3.66 & 41,790 & 49,383 \\
\hline PWR & $\mathrm{B} \& \mathrm{~W}$ & $\mathrm{~B} 1515 \mathrm{~B} 7$ & 463.244 & 464.513 & 3.48 & 3.51 & 3.55 & 42,059 & 48,738 \\
\hline PWR & $\mathrm{B} \& \mathrm{~W}$ & $\mathrm{~B} 1515 \mathrm{~B} 8$ & 464.864 & 468.560 & 3.29 & 3.65 & 4.01 & 42,692 & 54,000 \\
\hline PWR & $\mathrm{B} \& \mathrm{~W}$ & B1515B9 & 463.566 & 467.566 & 3.29 & 3.96 & 4.76 & 44,097 & 53,952 \\
\hline PWR & $\mathrm{B} \& \mathrm{~W}$ & B1515BGD & 429.552 & 430.255 & 3.92 & 3.92 & 3.92 & 49,027 & 58,310 \\
\hline PWR & $\mathrm{B} \& \mathrm{~W}$ & B1515BZ & 463.410 & 466.279 & 3.05 & 3.47 & 4.68 & 37,441 & 54,023 \\
\hline PWR & $\mathrm{B} \& \mathrm{~W}$ & $\mathrm{~B} 1717 \mathrm{~B}$ & 456.722 & 457.929 & 2.64 & 2.84 & 3.04 & 29,517 & 33,904 \\
\hline PWR & $\mathrm{B} \& \mathrm{~W}$ & W1414B & 383.157 & 383.157 & 3.22 & 3.22 & 3.22 & 24,398 & 24,465 \\
\hline PWR & $\mathrm{B} \& \mathrm{~W}$ & W1717B & 455.799 & 466.688 & 2.00 & 3.84 & 4.60 & 40,741 & 54,014 \\
\hline PWR & $\mathrm{B} \& \mathrm{~W}$ & XHN15B & 409.913 & 415.060 & 3.00 & 3.99 & 4.02 & 33,776 & 37,833 \\
\hline PWR & $\mathrm{B} \& \mathrm{~W}$ & XHN15BZ & 363.921 & 368.072 & 3.40 & 3.80 & 3.91 & 34,278 & 42,956 \\
\hline PWR & $\mathrm{CE}$ & $\mathrm{C} 1414 \mathrm{C}$ & 382.437 & 408.508 & 1.03 & 3.20 & 4.48 & 33,597 & 56,000 \\
\hline PWR & $\mathrm{CE}$ & C1616CSD & 413.912 & 442.986 & 1.87 & 3.62 & 4.63 & 37,916 & 63,328 \\
\hline PWR & $\mathrm{CE}$ & $\mathrm{C} 8016 \mathrm{C}$ & 421.468 & 442.000 & 1.92 & 3.57 & 4.27 & 38,490 & 56,312 \\
\hline PWR & $\mathrm{CE}$ & $\mathrm{XFC14C}$ & 362.313 & 376.842 & 1.39 & 2.96 & 3.95 & 32,130 & 52,125 \\
\hline PWR & $\mathrm{CE}$ & XPA15C & 412.442 & 416.780 & 1.65 & 2.47 & 3.06 & 16,020 & 33,630 \\
\hline PWR & $\mathrm{CE}$ & XSL16C & 381.018 & 394.400 & 1.72 & 3.44 & 4.28 & 38,807 & 54,838 \\
\hline PWR & $\mathrm{CE}$ & XYR16C & 228.766 & 233.400 & 3.51 & 3.80 & 3.92 & 24,282 & 35,999 \\
\hline
\end{tabular}


Table A-3 (continued)

\begin{tabular}{|c|c|c|c|c|c|c|c|c|c|}
\hline \multirow{2}{*}{$\begin{array}{c}\text { Reactor } \\
\text { type }\end{array}$} & \multirow{2}{*}{$\begin{array}{c}\text { Manufacturer } \\
\text { code }\end{array}$} & \multirow{2}{*}{$\begin{array}{c}\text { Assembly } \\
\text { code }\end{array}$} & \multicolumn{2}{|c|}{$\begin{array}{c}\text { Initial uranium } \\
\text { loading } \\
\text { (kg/assembly) }\end{array}$} & \multicolumn{3}{|c|}{$\begin{array}{l}\text { Enrichment } \\
\left(\mathbf{U}^{235} \text { wt \%) }\right.\end{array}$} & \multicolumn{2}{|c|}{$\begin{array}{c}\text { Burnup } \\
\text { (MWd/MTU) }\end{array}$} \\
\hline & & & Avg. & Max. & Min. & Avg. & Max. & Avg. & Max. \\
\hline PWR & GA & XHN15HS & 406.163 & 406.163 & 3.99 & 3.99 & 3.99 & 32,151 & 32,151 \\
\hline PWR & GA & XHN15HZ & 362.863 & 362.863 & 3.26 & 3.26 & 3.26 & 18,546 & 18,546 \\
\hline PWR & NU & XHN15MS & 405.979 & 406.992 & 3.66 & 3.66 & 3.66 & 28,324 & 28,324 \\
\hline PWR & NU & XHN15MZ & 370.776 & 371.039 & 2.95 & 2.95 & 2.95 & 25,643 & 25,643 \\
\hline PWR & UNC & XYR16U & 238.573 & 241.300 & 3.96 & 3.99 & 4.02 & 27,461 & 31,986 \\
\hline PWR & WE & B1515W & 461.819 & 464.763 & 3.90 & 4.06 & 4.22 & 36,993 & 49,075 \\
\hline PWR & WE & C1414W & 403.483 & 411.719 & 2.70 & 3.15 & 3.76 & 30,039 & 37,781 \\
\hline PWR & WE & W1414W & 393.896 & 403.683 & 2.26 & 3.04 & 3.47 & 27,315 & 39,723 \\
\hline PWR & WE & W1414WL & 399.092 & 405.809 & 2.27 & 3.07 & 3.41 & 31,940 & 47,932 \\
\hline PWR & WE & W1414WO & 355.724 & 369.265 & 0.99 & 3.92 & 4.95 & 44,730 & 69,452 \\
\hline PWR & WE & W1515W & 451.193 & 458.091 & 2.21 & 3.00 & 3.35 & 29,324 & 41,806 \\
\hline PWR & WE & W1515WL & 455.236 & 465.600 & 1.85 & 2.98 & 3.80 & 30,874 & 55,385 \\
\hline PWR & WE & W1515WO & 460.764 & 465.747 & 1.91 & 3.53 & 4.60 & 39,071 & 56,138 \\
\hline PWR & WE & W1515WV5 & 457.793 & 462.934 & 2.99 & 3.92 & 4.80 & 37,556 & 53,056 \\
\hline PWR & WE & W1717WL & 461.323 & 469.200 & 1.60 & 3.12 & 4.40 & 32,340 & 58,417 \\
\hline PWR & WE & W1717WO & 425.107 & 459.433 & 1.60 & 3.05 & 4.02 & 32,690 & 53,000 \\
\hline PWR & WE & W1717WP & 417.069 & 417.878 & 3.73 & 4.59 & 4.81 & 50,707 & 58,237 \\
\hline PWR & WE & W1717WRF & 455.497 & 456.735 & 4.00 & 4.18 & 4.42 & 45,530 & 48,037 \\
\hline PWR & WE & W1717WV & 425.399 & 426.042 & 4.21 & 4.38 & 4.41 & 44,263 & 48,385 \\
\hline PWR & WE & W1717WV+ & 424.010 & 465.469 & 1.61 & 4.16 & 4.66 & 45,430 & 61,685 \\
\hline PWR & WE & W1717WV5 & 424.269 & 430.925 & 1.49 & 4.01 & 4.95 & 43,872 & 56,570 \\
\hline PWR & WE & W1717WVH & 461.954 & 473.962 & 2.11 & 3.87 & 4.95 & 41,081 & 55,496 \\
\hline PWR & WE & W1717WVJ & 461.518 & 465.200 & 3.71 & 3.99 & 4.40 & 43,922 & 46,847 \\
\hline PWR & WE & WST17W & 540.480 & 546.600 & 1.51 & 3.38 & 4.41 & 35,926 & 54,399 \\
\hline PWR & WE & XFC14W & 374.055 & 376.000 & 0.27 & 3.75 & 4.25 & 38,521 & 51,971 \\
\hline PWR & WE & XHN15W & 415.557 & 421.227 & 3.02 & 3.59 & 4.00 & 27,922 & 35,196 \\
\hline PWR & WE & XHN15WZ & 384.894 & 386.689 & 4.20 & 4.39 & 4.60 & 14,321 & 19,376 \\
\hline PWR & WE & XIP14W & 191.152 & 200.467 & 2.83 & 4.12 & 4.36 & 16,471 & 27,048 \\
\hline PWR & WE & XSO14W & 368.153 & 374.885 & 3.16 & 3.87 & 4.02 & 27,232 & 39,275 \\
\hline PWR & WE & XSO14WD & 373.323 & 373.643 & 4.01 & 4.01 & 4.02 & 18,259 & 18,424 \\
\hline PWR & WE & XSO14WM & 311.225 & 311.225 & 0.71 & 0.71 & 0.71 & 19,307 & 19,636 \\
\hline PWR & WE & XYR18W & 273.350 & 274.100 & 4.94 & 4.94 & 4.94 & 25,484 & 31,755 \\
\hline
\end{tabular}


Table A-4. Summary of UNF characteristics from which representative samples may be selected [Ref. 5]

\begin{tabular}{|c|c|c|c|c|c|c|c|c|c|c|c|}
\hline $\begin{array}{c}\text { Assembly } \\
\text { code }\end{array}$ & Lattice & $\begin{array}{l}\text { Number of } \\
\text { assemblies }\end{array}$ & $\begin{array}{c}\text { Average } \\
\text { initial } \\
\text { kgU }\end{array}$ & $\begin{array}{c}\text { Minimum } \\
\text { final assay } \\
\text { average BU } \\
\text { (MWd/MTU) }\end{array}$ & $\begin{array}{c}\text { Maximum } \\
\text { final assay } \\
\text { average BU } \\
\text { (MWd/MTU) }\end{array}$ & $\begin{array}{l}\text { Minimum } \\
\text { assay } \\
\text { average } \\
\text { initial } \\
\text { enrichment } \\
\text { (wt \%) } \\
\end{array}$ & $\begin{array}{l}\text { Maximum } \\
\text { assay } \\
\text { average } \\
\text { initial } \\
\text { enrichment } \\
\text { (wt \%) } \\
\end{array}$ & $\begin{array}{c}\text { Minimum } \\
\text { cooling } \\
\text { time } \\
\text { thru } \\
2010 \\
\text { (years) }\end{array}$ & $\begin{array}{c}\text { Maximum } \\
\text { cooling } \\
\text { time } \\
\text { thru } \\
2010 \\
\text { (years) } \\
\end{array}$ & $\begin{array}{c}\text { Manu- } \\
\text { facturer }\end{array}$ & $\begin{array}{c}\text { Assay } \\
\text { length } \\
\text { (in.) }\end{array}$ \\
\hline C1414A & $14 \times 14$ & 1383 & 380.87 & 2000 & 50871 & 0.3 & 4.32 & 8.3 & 26.8 & ANF & 157 \\
\hline $\mathrm{C} 1414 \mathrm{C}$ & $14 \times 14$ & 4198 & 382.43 & 2768 & 56000 & 1.02 & 4.48 & 8.9 & 36.5 & $\mathrm{CE}$ & 157 \\
\hline C1414W & $14 \times 14$ & 552 & 403.48 & 7339 & 37781 & 2.69 & 3.76 & 14.1 & 27.6 & WE & 157 \\
\hline W1414A & $14 \times 14$ & 1018 & 378.27 & 24961 & 56328 & 0.71 & 4.5 & 9.3 & 33.7 & ANF & 159.8 \\
\hline W1414ATR & $14 \times 14$ & 288 & 362.78 & 23144 & 46000 & 2.39 & 3.57 & 18.9 & 26.3 & ANF & 159.8 \\
\hline W1414B & $14 \times 14$ & 2 & 383.15 & 24330 & 24465 & 3.22 & 3.22 & 33.7 & 33.7 & $\mathrm{~B} \& \mathrm{~W}$ & 159.8 \\
\hline W1414W & $14 \times 14$ & 603 & 393.89 & 5582 & 39723 & 2.25 & 3.47 & 24.8 & 39.9 & WE & 159.8 \\
\hline W1414WL & $14 \times 14$ & 1429 & 399.09 & 10774 & 47932 & 2.26 & 3.4 & 16.7 & 38.3 & WE & 159.8 \\
\hline W1414WO & $14 \times 14$ & 2108 & 355.72 & 12670 & 69452 & 0.99 & 4.95 & 8.1 & 27.8 & WE & 159.8 \\
\hline XFC14A & $14 \times 14$ & 192 & 353.34 & 24119 & 46048 & 3.5 & 3.8 & 18.9 & 26.8 & ANF & 146 \\
\hline $\mathrm{XFC} 14 \mathrm{C}$ & $14 \times 14$ & 418 & 362.31 & 7936 & 52125 & 1.39 & 3.95 & 9.8 & 35.9 & $\mathrm{CE}$ & 146 \\
\hline XFC14W & $14 \times 14$ & 229 & 374.05 & 10492 & 51971 & 0.27 & 4.25 & 8.7 & 14.2 & WE & 146 \\
\hline XIP14W & $14 \times 14$ & 160 & 191.15 & 3704 & 27048 & 2.83 & 4.36 & 36.2 & 38.0 & WE & 138.8 \\
\hline XSO14W & $14 \times 14$ & 657 & 368.15 & 6800 & 39275 & 3.15 & 4.02 & 18.1 & 40.2 & WE & 137.1 \\
\hline XSO14WD & $14 \times 14$ & 4 & 373.32 & 18154 & 18424 & 4.01 & 4.01 & 18.1 & 18.1 & WE & 137.1 \\
\hline XSO14WM & $14 \times 14$ & 4 & 311.22 & 19061 & 19636 & 0.71 & 0.71 & 37.6 & 37.6 & WE & 137.1 \\
\hline $\mathrm{B} 1515 \mathrm{~B}$ & $15 \times 15$ & 103 & 463.39 & 4286 & 50128 & 2.74 & 3.62 & 8.2 & 14.2 & $\mathrm{~B} \& \mathrm{~W}$ & 165.7 \\
\hline $\mathrm{B} 1515 \mathrm{~B} 10$ & $15 \times 15$ & 681 & 476.76 & 28791 & 56880 & 3.24 & 4.73 & 8.2 & 15.2 & $\mathrm{~B} \& \mathrm{~W}$ & 165.7 \\
\hline $\mathrm{B} 1515 \mathrm{~B} 3$ & $15 \times 15$ & 181 & 463.84 & 8652 & 32267 & 1.07 & 2.83 & 16.7 & 32.8 & $\mathrm{~B} \& \mathrm{~W}$ & 165.7 \\
\hline $\mathrm{B} 1515 \mathrm{~B} 4$ & $15 \times 15$ & 4136 & 464.28 & 10809 & 57000 & 0.9 & 4.06 & 8.2 & 36.2 & $\mathrm{~B} \& \mathrm{~W}$ & 165.7 \\
\hline $\mathrm{B} 1515 \mathrm{~B} 4 \mathrm{Z}$ & $15 \times 15$ & 170 & 463.73 & 33119 & 51660 & 3.21 & 3.95 & 9.3 & 18.7 & $\mathrm{~B} \& \mathrm{~W}$ & 165.7 \\
\hline B1515B5 & $15 \times 15$ & 58 & 468.25 & 38000 & 39000 & 3.13 & 3.13 & 16.2 & 17.8 & $\mathrm{~B} \& \mathrm{~W}$ & 165.7 \\
\hline B1515B5Z & $15 \times 15$ & 29 & 464.42 & 34116 & 42328 & 3.2 & 3.23 & 17.7 & 19.0 & $\mathrm{~B} \& \mathrm{~W}$ & 165.7 \\
\hline
\end{tabular}


Table A-4 (continued)

\begin{tabular}{|c|c|c|c|c|c|c|c|c|c|c|c|}
\hline $\begin{array}{c}\text { Assembly } \\
\text { code }\end{array}$ & Lattice & $\begin{array}{l}\text { Number of } \\
\text { assemblies }\end{array}$ & $\begin{array}{c}\text { Average } \\
\text { initial } \\
\text { kgU } \\
\end{array}$ & $\begin{array}{c}\text { Minimum } \\
\text { final assay } \\
\text { average BU } \\
\text { (MWd/MTU) }\end{array}$ & $\begin{array}{c}\text { Maximum } \\
\text { final assay } \\
\text { average BU } \\
\text { (MWd/MTU) }\end{array}$ & $\begin{array}{l}\text { Minimum } \\
\text { assay } \\
\text { average } \\
\text { initial } \\
\text { enrichment } \\
\text { (wt \%) } \\
\end{array}$ & $\begin{array}{c}\text { Maximum } \\
\text { assay } \\
\text { average } \\
\text { initial } \\
\text { enrichment } \\
\text { (wt \%) } \\
\end{array}$ & $\begin{array}{c}\text { Minimum } \\
\text { cooling } \\
\text { time } \\
\text { thru } \\
2010 \\
\text { (years) } \\
\end{array}$ & $\begin{array}{c}\text { Maximum } \\
\text { cooling } \\
\text { time } \\
\text { thru } \\
2010 \\
\text { (years) } \\
\end{array}$ & $\begin{array}{c}\text { Manu- } \\
\text { facturer }\end{array}$ & $\begin{array}{c}\text { Assay } \\
\text { length } \\
\text { (in.) } \\
\end{array}$ \\
\hline B1515B6 & $15 \times 15$ & 130 & 462.49 & 35247 & 49383 & 3.22 & 3.66 & 16.7 & 19.0 & $\mathrm{~B} \& \mathrm{~W}$ & 165.7 \\
\hline B1515B7 & $15 \times 15$ & 96 & 463.24 & 37204 & 48738 & 3.47 & 3.55 & 17.0 & 18.4 & $\mathrm{~B} \& \mathrm{~W}$ & 165.7 \\
\hline $\mathrm{B} 1515 \mathrm{~B} 8$ & $15 \times 15$ & 798 & 464.86 & 27124 & 54000 & 3.28 & 4.01 & 8.9 & 17.8 & $\mathrm{~B} \& \mathrm{~W}$ & 165.7 \\
\hline B1515B9 & $15 \times 15$ & 276 & 463.56 & 22796 & 53952 & 3.29 & 4.75 & 11.2 & 16.7 & $\mathrm{~B} \& \mathrm{~W}$ & 165.7 \\
\hline B1515BGD & $15 \times 15$ & 4 & 429.55 & 45785 & 58310 & 3.91 & 3.92 & 22.0 & 23.3 & $\mathrm{~B} \& \mathrm{~W}$ & 165.7 \\
\hline $\mathrm{B} 1515 \mathrm{BZ}$ & $15 \times 15$ & 848 & 463.41 & 10000 & 54023 & 3.05 & 4.67 & 9.3 & 24.0 & $\mathrm{~B} \& \mathrm{~W}$ & 165.7 \\
\hline $\mathrm{B} 1515 \mathrm{~W}$ & $15 \times 15$ & 8 & 461.82 & 25076 & 49075 & 3.9 & 4.21 & 11.3 & 17.3 & WE & 165.7 \\
\hline W1515A & $15 \times 15$ & 889 & 428.88 & 20298 & 49859 & 2.01 & 3.6 & 11.3 & 31.7 & ANF & 159.8 \\
\hline W1515AHT & $15 \times 15$ & 308 & 434.54 & 32682 & 56922 & 3.51 & 4.58 & 8.2 & 15.7 & ANF & 159.8 \\
\hline W1515APL & $15 \times 15$ & 24 & 307.36 & 21470 & 37770 & 1.22 & 1.87 & 8.2 & 17.3 & ANF & 159.8 \\
\hline $\mathrm{W} 1515 \mathrm{~W}$ & $15 \times 15$ & 393 & 451.19 & 12034 & 41806 & 2.21 & 3.34 & 25.0 & 34.8 & WE & 159.8 \\
\hline W1515WL & $15 \times 15$ & 4644 & 455.23 & 8381 & 55385 & 1.85 & 3.8 & 13.8 & 37.8 & WE & 159.8 \\
\hline W1515WO & $15 \times 15$ & 3576 & 460.76 & 5816 & 56138 & 1.91 & 4.59 & 8.7 & 25.7 & WE & 159.8 \\
\hline W1515WV5 & $15 \times 15$ & 531 & 457.79 & 14227 & 53056 & 2.98 & 4.79 & 8.2 & 15.3 & WE & 159.8 \\
\hline XHN15B & $15 \times 15$ & 629 & 409.91 & 8193 & 37833 & 3 & 4.01 & 14.4 & 33.2 & $\mathrm{~B} \& W$ & 137.1 \\
\hline XHN15BZ & $15 \times 15$ & 104 & 363.92 & 23813 & 42956 & 3.4 & 3.91 & 14.4 & 21.3 & $\mathrm{~B} \& \mathrm{~W}$ & 137.1 \\
\hline XHN15HS & $15 \times 15$ & 1 & 406.16 & 32151 & 32151 & 3.98 & 3.98 & 35.6 & 35.6 & Gulf & 137.1 \\
\hline XHN15HZ & $15 \times 15$ & 2 & 362.86 & 18546 & 18546 & 3.25 & 3.25 & 37.5 & 37.5 & Gulf & 137.1 \\
\hline XHN15MS & $15 \times 15$ & 2 & 405.98 & 28324 & 28324 & 3.66 & 3.66 & 37.5 & 37.5 & NU & 137.1 \\
\hline XHN15MZ & $15 \times 15$ & 2 & 370.77 & 25643 & 25643 & 2.95 & 2.95 & 37.5 & 37.5 & NU & 137.1 \\
\hline XHN15W & $15 \times 15$ & 309 & 415.55 & 10742 & 35196 & 3.02 & 4 & 33.2 & 40.7 & WE & 137.1 \\
\hline XHN15WZ & $15 \times 15$ & 53 & 384.89 & 8874 & 19376 & 4.2 & 4.6 & 14.4 & 14.4 & WE & 137.1 \\
\hline XPA15A & $15 \times 15$ & 808 & 396.67 & 11837 & 51486 & 1.49 & 4.04 & 9.8 & 33.0 & ANF & 147.5 \\
\hline XPA15C & $15 \times 15$ & 273 & 412.44 & 5139 & 33630 & 1.65 & 3.06 & 29.3 & 35.0 & $\mathrm{CE}$ & 147.5 \\
\hline XYR16A & $15 \times 16$ & 228 & 233.56 & 22631 & 35088 & 3.49 & 4.02 & 23.7 & 32.2 & ANF & 111.8 \\
\hline XYR16C & $15 \times 16$ & 156 & 228.77 & 6039 & 35999 & 3.51 & 3.92 & 19.2 & 22.1 & $\mathrm{CE}$ & 111.8 \\
\hline
\end{tabular}


Table A-4 (continued)

\begin{tabular}{|c|c|c|c|c|c|c|c|c|c|c|c|}
\hline $\begin{array}{c}\text { Assembly } \\
\text { code }\end{array}$ & Lattice & $\begin{array}{l}\text { Number of } \\
\text { assemblies }\end{array}$ & $\begin{array}{c}\text { Average } \\
\text { initial } \\
\text { kgU }\end{array}$ & $\begin{array}{c}\text { Minimum } \\
\text { final assay } \\
\text { average BU } \\
\text { (MWd/MTU) }\end{array}$ & $\begin{array}{c}\text { Maximum } \\
\text { final assay } \\
\text { average BU } \\
\text { (MWd/MTU) }\end{array}$ & $\begin{array}{l}\text { Minimum } \\
\text { assay } \\
\text { average } \\
\text { initial } \\
\text { enrichment } \\
\text { (wt \%) } \\
\end{array}$ & $\begin{array}{c}\text { Maximum } \\
\text { assay } \\
\text { average } \\
\text { initial } \\
\text { enrichment } \\
\text { (wt \%) } \\
\end{array}$ & $\begin{array}{c}\text { Minimum } \\
\text { cooling } \\
\text { time } \\
\text { thru } \\
2010 \\
\text { (years) } \\
\end{array}$ & $\begin{array}{c}\text { Maximum } \\
\text { cooling } \\
\text { time } \\
\text { thru } \\
2010 \\
\text { (years) } \\
\end{array}$ & $\begin{array}{c}\text { Manu- } \\
\text { facturer }\end{array}$ & $\begin{array}{c}\text { Assay } \\
\text { length } \\
\text { (in.) } \\
\end{array}$ \\
\hline XYR16U & $15 \times 16$ & 73 & 238.57 & 4244 & 31986 & 3.96 & 4.02 & 33.6 & 36.6 & UNC & 111.8 \\
\hline $\mathrm{C} 1616 \mathrm{CSD}$ & $16 \times 16$ & 4080 & 414.01 & 11053 & 63328 & 1.86 & 4.63 & 8.6 & 29.8 & $\mathrm{CE}$ & 176.8 \\
\hline $\mathrm{C} 8016 \mathrm{C}$ & $16 \times 16$ & 2747 & 421.47 & 13902 & 56312 & 1.92 & 4.27 & 8.3 & 23.2 & $\mathrm{CE}$ & 178.3 \\
\hline XSL16C & $16 \times 16$ & 909 & 381.02 & 9867 & 54838 & 1.71 & 4.28 & 9.1 & 26.2 & $\mathrm{CE}$ & 158.2 \\
\hline $\mathrm{B} 1717 \mathrm{~B}$ & $17 \times 17$ & 4 & 456.72 & 25123 & 33904 & 2.64 & 3.03 & 29.0 & 30.8 & $\mathrm{~B} \& \mathrm{~W}$ & 165.7 \\
\hline W1717A & $17 \times 17$ & 1210 & 413.84 & 20607 & 53958 & 2.43 & 4.77 & 8.3 & 24.8 & ANF & 159.8 \\
\hline W1717B & $17 \times 17$ & 2060 & 455.80 & 5000 & 54014 & 2 & 4.6 & 8.3 & 19.3 & $\mathrm{~B} \& \mathrm{~W}$ & 159.8 \\
\hline W1717WL & $17 \times 17$ & 10097 & 461.32 & 7227 & 58417 & 1.6 & 4.4 & 8.7 & 32.8 & WE & 159.8 \\
\hline W1717WO & $17 \times 17$ & 3204 & 425.10 & 12030 & 53000 & 1.6 & 4.02 & 8.8 & 26.9 & WE & 159.8 \\
\hline W1717WP & $17 \times 17$ & 216 & 417.07 & 44578 & 58237 & 3.73 & 4.81 & 8.7 & 13.2 & WE & 159.8 \\
\hline W1717WRF & $17 \times 17$ & 72 & 455.49 & 42342 & 48037 & 3.99 & 4.41 & 8.2 & 10.3 & WE & 159.8 \\
\hline W1717WV & $17 \times 17$ & 24 & 425.40 & 37862 & 48385 & 4.2 & 4.41 & 11.2 & 11.2 & WE & 159.8 \\
\hline W1717WV+ & $17 \times 17$ & 2126 & 424.01 & 21649 & 61685 & 1.61 & 4.65 & 8.2 & 16.3 & WE & 159.8 \\
\hline W1717WV5 & $17 \times 17$ & 4469 & 424.27 & 18865 & 56570 & 1.49 & 4.95 & 8.3 & 22.3 & WE & 159.8 \\
\hline W1717WVH & $17 \times 17$ & 3868 & 461.95 & 11804 & 55496 & 2.11 & 4.95 & 8.2 & 19.9 & WE & 159.8 \\
\hline W1717WVJ & $17 \times 17$ & 104 & 461.52 & 34132 & 46847 & 3.71 & 4.4 & 8.8 & 10.3 & WE & 159.8 \\
\hline WST17W & $17 \times 17$ & 1254 & 540.48 & 10825 & 54399 & 1.5 & 4.41 & 8.2 & 21.4 & WE & 199 \\
\hline XYR18W & $17 \times 18$ & 76 & 273.35 & 19054 & 31755 & 4.94 & 4.94 & 35.2 & 38.9 & WE & 111.8 \\
\hline G4806G10 & $6 \times 6$ & 11 & 178.57 & 5679 & 36591 & 3.06 & 4 & 8.7 & 11.8 & $\mathrm{GE}$ & 176.2 \\
\hline XDR06A & $6 \times 6$ & 66 & 95.20 & 3241 & 5742 & 2.23 & 2.23 & 32.2 & 32.2 & ANF & 134.4 \\
\hline XDR06G & $6 \times 6$ & 1 & 111 & 23522 & 23522 & 1.47 & 1.47 & 41.3 & 41.3 & GE & 134.4 \\
\hline XDR06G3B & $6 \times 6$ & 163 & 101.61 & 9755 & 27106 & 1.82 & 1.83 & 33.5 & 41.3 & GE & 134.4 \\
\hline XDR06G3F & $6 \times 6$ & 96 & 102.04 & 12387 & 28138 & 2.24 & 2.25 & 33.5 & 41.3 & $\mathrm{GE}$ & 134.4 \\
\hline XDR06G5 & $6 \times 6$ & 106 & 105.85 & 9065 & 25886 & 2.26 & 2.26 & 32.2 & 41.3 & GE & 134.4 \\
\hline XDR06U & $6 \times 6$ & 458 & 102.02 & 4164 & 26396 & 1.83 & 2.26 & 32.2 & 41.3 & UNC & 134.4 \\
\hline XHB06A & $6 \times 6$ & 126 & 69.73 & 1307 & 22377 & 2.35 & 2.41 & 34.5 & 35.6 & ANF & 95 \\
\hline
\end{tabular}


Table A-4 (continued)

\begin{tabular}{|c|c|c|c|c|c|c|c|c|c|c|c|}
\hline $\begin{array}{c}\text { Assembly } \\
\text { code }\end{array}$ & Lattice & $\begin{array}{l}\text { Number of } \\
\text { assemblies }\end{array}$ & $\begin{array}{c}\text { Average } \\
\text { initial } \\
\text { kgU }\end{array}$ & $\begin{array}{c}\text { Minimum } \\
\text { final assay } \\
\text { average BU } \\
\text { (MWd/MTU) }\end{array}$ & $\begin{array}{c}\text { Maximum } \\
\text { final assay } \\
\text { average BU } \\
\text { (MWd/MTU) }\end{array}$ & $\begin{array}{l}\text { Minimum } \\
\text { assay } \\
\text { average } \\
\text { initial } \\
\text { enrichment } \\
\text { (wt \%) } \\
\end{array}$ & $\begin{array}{l}\text { Maximum } \\
\text { assay } \\
\text { average } \\
\text { initial } \\
\text { enrichment } \\
\text { (wt \%) } \\
\end{array}$ & $\begin{array}{c}\text { Minimum } \\
\text { cooling } \\
\text { time } \\
\text { thru } \\
2010 \\
\text { (years) } \\
\end{array}$ & $\begin{array}{c}\text { Maximum } \\
\text { cooling } \\
\text { time } \\
\text { thru } \\
2010 \\
\text { (years) } \\
\end{array}$ & $\begin{array}{c}\text { Manu- } \\
\text { facturer }\end{array}$ & $\begin{array}{c}\text { Assay } \\
\text { length } \\
\text { (in.) } \\
\end{array}$ \\
\hline XHB06G & $6 \times 6$ & 176 & 76.35 & 6119 & 22876 & 2.35 & 2.52 & 34.5 & 39.6 & GE & 95 \\
\hline G2307A & $7 \times 7$ & 152 & 181.57 & 17663 & 27826 & 2.56 & 2.65 & 31.0 & 33.7 & ANF & 171.2 \\
\hline G2307G2A & $7 \times 7$ & 1672 & 194.90 & 4493 & 24902 & 2.06 & 2.11 & 31.7 & 39.3 & GE & 171.2 \\
\hline $\mathrm{G} 2307 \mathrm{G} 2 \mathrm{~B}$ & $7 \times 7$ & 5047 & 193.20 & 177 & 29728 & 1.65 & 2.62 & 29.3 & 40.6 & GE & 171.2 \\
\hline G2307G3 & $7 \times 7$ & 395 & 187.42 & 5607 & 38861 & 1.96 & 2.6 & 26.7 & 35.3 & GE & 171.2 \\
\hline $\mathrm{G} 4607 \mathrm{G} 2$ & $7 \times 7$ & 1142 & 194.72 & 959 & 11829 & 1.09 & 2.5 & 31.7 & 37.3 & GE & 176.2 \\
\hline G4607G3A & $7 \times 7$ & 3752 & 187.45 & 2317 & 32188 & 1.1 & 2.51 & 25.1 & 35.6 & GE & 176.2 \\
\hline G4607G3B & $7 \times 7$ & 1184 & 189.92 & 7695 & 30831 & 1.09 & 2.5 & 28.6 & 34.3 & GE & 176.2 \\
\hline XBR07G & $7 \times 7$ & 4 & 131.50 & 1596 & 1690 & 2.88 & 2.88 & 42.5 & 42.5 & GE & 84 \\
\hline XDR07GS & $7 \times 7$ & 1 & 59 & 29000 & 29000 & 3.1 & 3.1 & 41.3 & 41.3 & GE & 134.4 \\
\hline XHB07G2 & $7 \times 7$ & 88 & 76.33 & 15136 & 20770 & 2.08 & 2.31 & 37.3 & 39.6 & GE & 95 \\
\hline G2308A & $8 \times 8$ & 1517 & 174.62 & 16205 & 36826 & 2.39 & 3.13 & 18.0 & 32.3 & ANF & 171.2 \\
\hline G2308AP & $8 \times 8$ & 32 & 172.75 & 33686 & 34826 & 2.82 & 2.83 & 16.8 & 16.8 & ANF & 171.2 \\
\hline G2308G10 & $8 \times 8$ & 1404 & 172.22 & 5624 & 43977 & 3.1 & 3.55 & 8.2 & 15.2 & GE & 171.2 \\
\hline G2308G4 & $8 \times 8$ & 3944 & 183.99 & 16646 & 40523 & 2.19 & 2.75 & 23.2 & 32.2 & GE & 171.2 \\
\hline G2308G5 & $8 \times 8$ & 810 & 176.97 & 22519 & 33597 & 2.39 & 2.82 & 19.9 & 28.3 & GE & 171.2 \\
\hline G2308G7 & $8 \times 8$ & 164 & 178.52 & 29145 & 35894 & 2.96 & 2.99 & 15.9 & 15.9 & GE & 171.2 \\
\hline G2308G8A & $8 \times 8$ & 1150 & 175.69 & 30074 & 44933 & 2.54 & 3.4 & 12.1 & 19.8 & GE & 171.2 \\
\hline G2308G8B & $8 \times 8$ & 1382 & 172.36 & 21331 & 42518 & 2.95 & 3.39 & 10.2 & 17.9 & GE & 171.2 \\
\hline G2308G9 & $8 \times 8$ & 890 & 172.01 & 32167 & 42295 & 2.85 & 3.48 & 8.2 & 14.7 & GE & 171.2 \\
\hline G2308GB & $8 \times 8$ & 1367 & 177.98 & 21943 & 43381 & 2.62 & 3.39 & 13.8 & 25.0 & GE & 171.2 \\
\hline G2308GP & $8 \times 8$ & 3281 & 177.14 & 22466 & 38139 & 2.08 & 3.01 & 15.8 & 25.8 & GE & 171.2 \\
\hline G4608AP & $8 \times 8$ & 1888 & 176.17 & 23000 & 35518 & 2.62 & 3.4 & 13.8 & 21.8 & ANF & 176.2 \\
\hline G4608G10 & $8 \times 8$ & 2337 & 177.77 & 18762 & 44343 & 2.63 & 3.7 & 8.7 & 17.8 & GE & 176.2 \\
\hline G4608G11 & $8 \times 8$ & 236 & 170.79 & 26390 & 42551 & 3.38 & 3.38 & 9.9 & 11.8 & GE & 176.2 \\
\hline $\mathrm{G} 4608 \mathrm{G} 12$ & $8 \times 8$ & 88 & 180.87 & 13493 & 34462 & 3.69 & 3.99 & 9.9 & 11.8 & GE & 176.2 \\
\hline
\end{tabular}


Table A-4 (continued)

\begin{tabular}{|c|c|c|c|c|c|c|c|c|c|c|c|}
\hline $\begin{array}{c}\text { Assembly } \\
\text { code }\end{array}$ & Lattice & $\begin{array}{l}\text { Number of } \\
\text { assemblies }\end{array}$ & $\begin{array}{c}\text { Average } \\
\text { initial } \\
\text { kgU }\end{array}$ & $\begin{array}{c}\text { Minimum } \\
\text { final assay } \\
\text { average BU } \\
\text { (MWd/MTU) }\end{array}$ & $\begin{array}{c}\text { Maximum } \\
\text { final assay } \\
\text { average BU } \\
\text { (MWd/MTU) }\end{array}$ & $\begin{array}{l}\text { Minimum } \\
\text { assay } \\
\text { average } \\
\text { initial } \\
\text { enrichment } \\
\text { (wt \%) } \\
\end{array}$ & $\begin{array}{c}\text { Maximum } \\
\text { assay } \\
\text { average } \\
\text { initial } \\
\text { enrichment } \\
\text { (wt \%) } \\
\end{array}$ & $\begin{array}{c}\text { Minimum } \\
\text { cooling } \\
\text { time } \\
\text { thru } \\
2010 \\
\text { (years) } \\
\end{array}$ & $\begin{array}{c}\text { Maximum } \\
\text { cooling } \\
\text { time } \\
\text { thru } \\
2010 \\
\text { (years) } \\
\end{array}$ & $\begin{array}{c}\text { Manu- } \\
\text { facturer }\end{array}$ & $\begin{array}{c}\text { Assay } \\
\text { length } \\
\text { (in.) } \\
\end{array}$ \\
\hline G4608G4A & $8 \times 8$ & 1785 & 183.93 & 5750 & 43430 & 2.19 & 2.99 & 18.8 & 33.4 & $\mathrm{GE}$ & 176.2 \\
\hline G4608G4B & $8 \times 8$ & 1227 & 186.82 & 13379 & 32941 & 2.17 & 2.75 & 26.3 & 32.3 & GE & 176.2 \\
\hline G4608G5 & $8 \times 8$ & 4213 & 183.00 & 1829 & 38224 & 0.69 & 3.01 & 14.9 & 31.0 & GE & 176.2 \\
\hline G4608G8 & $8 \times 8$ & 3919 & 179.84 & 1969 & 44640 & 2.94 & 3.4 & 9.3 & 20.3 & GE & 176.2 \\
\hline G4608G8B & $8 \times 8$ & 57 & 178.00 & 32647 & 38396 & 3.36 & 3.39 & 14.2 & 14.2 & $\mathrm{GE}$ & 176.2 \\
\hline G4608G9 & $8 \times 8$ & 7146 & 177.73 & 8722 & 47062 & 1.5 & 3.87 & 8.2 & 18.3 & GE & 176.2 \\
\hline G4608GB & $8 \times 8$ & 10246 & 184.63 & 1814 & 45986 & 0.71 & 3.25 & 10.2 & 26.3 & $\mathrm{GE}$ & 176.2 \\
\hline G4608GP & $8 \times 8$ & 12642 & 183.19 & 1676 & 42428 & 0.7 & 3.26 & 8.8 & 29.8 & GE & 176.2 \\
\hline G4608W & $8 \times 8$ & 8 & 156.70 & 23000 & 33140 & 2.69 & 3.01 & 14.8 & 19.1 & WE & 176.2 \\
\hline XBR08G & $8 \times 8$ & 2 & 112.5 & 2065 & 7027 & 2.85 & 2.85 & 41.7 & 42.5 & $\mathrm{GE}$ & 84 \\
\hline XDR08G & $8 \times 8$ & 1 & 99.71 & 25287 & 25287 & 1.94 & 1.94 & 41.3 & 41.3 & $\mathrm{GE}$ & 134.4 \\
\hline 9X9IXQFA & $9 \times 9$ & 8 & 170.71 & 39079 & 39248 & 3.25 & 3.25 & 11.0 & 11.0 & $?$ & 171.2 \\
\hline G2309A & $9 \times 9$ & 1820 & 168.09 & 6210 & 40818 & 2.77 & 3.15 & 8.2 & 20.3 & ANF & 171.2 \\
\hline G2309AIX & $9 \times 9$ & 224 & 169.18 & 11933 & 43778 & 3.25 & 3.81 & 8.2 & 9.2 & ANF & 171.2 \\
\hline G2309G11 & $9 \times 9$ & 132 & 165.65 & 31737 & 45117 & 3.1 & 3.78 & 9.2 & 13.8 & $\mathrm{GE}$ & 171.2 \\
\hline G4609A & $9 \times 9$ & 3280 & 172.97 & 4000 & 47000 & 0.72 & 3.73 & 8.8 & 21.3 & ANF & 176.2 \\
\hline G4609A5 & $9 \times 9$ & 1124 & 176.15 & 28632 & 43555 & 2.9 & 3.55 & 9.7 & 17.3 & ANF & 176.2 \\
\hline G4609A9X & $9 \times 9$ & 768 & 169.16 & 30682 & 43330 & 2.53 & 3.11 & 9.6 & 15.7 & ANF & 176.2 \\
\hline G4609AIX & $9 \times 9$ & 12 & 174.79 & 16164 & 36777 & 3 & 3.93 & 8.2 & 17.3 & ANF & 176.2 \\
\hline G4609AX+ & $9 \times 9$ & 8 & 167.26 & 38043 & 40457 & 3.13 & 3.14 & 13.9 & 14.3 & ANF & 176.2 \\
\hline G4609G11 & $9 \times 9$ & 5351 & 170.12 & 5835 & 65149 & 1.46 & 4.14 & 8.3 & 16.9 & GE & 176.2 \\
\hline G4609G13 & $9 \times 9$ & 2060 & 171.41 & 11810 & 53636 & 3.23 & 4.17 & 8.2 & 14.8 & GE & 176.2 \\
\hline XBR09A & $9 \times 9$ & 4 & 127.68 & 19061 & 22811 & 3.44 & 3.51 & 33.4 & 34.9 & ANF & 84 \\
\hline XBR09G & $9 \times 9$ & 143 & 137.09 & 4802 & 22083 & 3.5 & 3.62 & 30.2 & 39.9 & GE & 84 \\
\hline ATRIUM10 & $10 \times 10$ & 128 & 176.90 & 37000 & 39000 & 3.94 & 3.94 & 9.8 & 9.8 & ANP & 176.2 \\
\hline G4610A & $10 \times 10$ & 116 & 176.90 & 37000 & 39000 & 3.94 & 3.94 & 8.8 & 8.8 & ANF & 176.2 \\
\hline
\end{tabular}


Table A-4 (continued)

\begin{tabular}{|c|c|c|c|c|c|c|c|c|c|c|c|}
\hline $\begin{array}{c}\text { Assembly } \\
\text { code }\end{array}$ & Lattice & $\begin{array}{l}\text { Number of } \\
\text { assemblies }\end{array}$ & $\begin{array}{c}\text { Average } \\
\text { initial } \\
\text { kgU } \\
\end{array}$ & $\begin{array}{c}\text { Minimum } \\
\text { final assay } \\
\text { average BU } \\
\text { (MWd/MTU) }\end{array}$ & $\begin{array}{c}\text { Maximum } \\
\text { final assay } \\
\text { average BU } \\
\text { (MWd/MTU) }\end{array}$ & $\begin{array}{c}\text { Minimum } \\
\text { assay } \\
\text { average } \\
\text { initial } \\
\text { enrichment } \\
\text { (wt \%) } \\
\end{array}$ & $\begin{array}{l}\text { Maximum } \\
\text { assay } \\
\text { average } \\
\text { initial } \\
\text { enrichment } \\
\text { (wt \%) } \\
\end{array}$ & $\begin{array}{c}\text { Minimum } \\
\text { cooling } \\
\text { time } \\
\text { thru } \\
2010 \\
\text { (years) } \\
\end{array}$ & $\begin{array}{c}\text { Maximum } \\
\text { cooling } \\
\text { time } \\
\text { thru } \\
2010 \\
\text { (years) } \\
\end{array}$ & $\begin{array}{c}\text { Manu- } \\
\text { facturer }\end{array}$ & $\begin{array}{c}\text { Assay } \\
\text { length } \\
\text { (in.) } \\
\end{array}$ \\
\hline G4610AIX & $10 \times 10$ & 4 & 175.00 & 37412 & 38009 & 3.39 & 3.39 & 10.2 & 10.2 & ANF & 176.2 \\
\hline G4610C & $10 \times 10$ & 148 & 175.68 & 17636 & 42640 & 2.51 & 3.62 & 9.6 & 14.8 & $\mathrm{ABB}$ & 176.2 \\
\hline G4610G12 & $10 \times 10$ & 371 & 176.09 & 36534 & 52735 & 3.12 & 4.2 & 8.2 & 10.3 & GE & 176.2 \\
\hline G4610G14 & $10 \times 10$ & 5 & 178.90 & 4365 & 38073 & 4.01 & 4.24 & 8.2 & 8.7 & GE & 176.2 \\
\hline XLC10A & $10 \times 10$ & 178 & 108.6523 & 4678 & 20126 & 3.68 & 3.7 & 23.7 & 28.7 & $\mathrm{AC}$ & 102.5 \\
\hline XLC10L & $10 \times 10$ & 156 & $\begin{array}{c}120.1547 \\
4 \\
\end{array}$ & 1591 & 21532 & 3.63 & 3.93 & 28.7 & 41.2 & ANF & 102.5 \\
\hline XBR11A & $11 \times 11$ & 360 & $\begin{array}{c}130.2331 \\
7 \\
\end{array}$ & 3514 & 34212 & 3.13 & 3.82 & 13.3 & 31.9 & ANF & 84 \\
\hline XBR11G & $11 \times 11$ & 6 & 124.5 & 20189 & 24997 & 3.11 & 3.63 & 38.8 & 38.8 & GE & 84 \\
\hline XBR11N & $11 \times 11$ & 8 & 128.9875 & 15875 & 21850 & 2.16 & 3.5 & 33.4 & 36.6 & NFS & 84 \\
\hline
\end{tabular}


Table A-5. Summary of UNF characteristics from which representative samples may be selected for PWR fuel assemblies [Ref. 5]

\begin{tabular}{|c|c|c|c|c|c|c|c|c|c|c|}
\hline \multirow{2}{*}{$\begin{array}{l}\text { Assembly } \\
\text { code }\end{array}$} & \multirow{2}{*}{$\begin{array}{l}\text { Number of } \\
\text { assemblies }\end{array}$} & \multicolumn{2}{|c|}{$\begin{array}{c}\text { Initial } \\
\text { uranium } \\
\text { loading } \\
\text { (kg/assembly) }\end{array}$} & \multicolumn{3}{|c|}{$\begin{array}{l}\text { Enrichment } \\
\left(\mathbf{U}^{235} w t \%\right)\end{array}$} & \multicolumn{2}{|c|}{$\begin{array}{c}\text { Burnup } \\
\text { (MWd/MTHM) }\end{array}$} & \multicolumn{2}{|c|}{$\begin{array}{c}\text { Cooling } \\
\text { time thru } \\
2010 \\
\text { (years) } \\
\end{array}$} \\
\hline & & Avg. & Max. & Min. & Avg. & Max. & Avg. & Max. & Min. & Max \\
\hline B1515B & 103 & 463 & 465 & 2.74 & 3.57 & 3.62 & 40,407 & 50,128 & 8.2 & 14.2 \\
\hline $\mathrm{B} 1515 \mathrm{~B} 10$ & 681 & 477 & 489 & 3.24 & 3.9 & 4.73 & 44,417 & 56,880 & 8.2 & 15.2 \\
\hline B1515B3 & 181 & 464 & 466 & 1.08 & 2.42 & 2.84 & 21,036 & 32,267 & 16.7 & 32.8 \\
\hline B1515B4 & 4136 & 464 & 475 & 0.9 & 2.91 & 4.06 & 29,534 & 57,000 & 8.2 & 36.2 \\
\hline B1515B4Z & 170 & 464 & 466 & 3.22 & 3.84 & 3.95 & 39,253 & 51,660 & 9.3 & 18.7 \\
\hline B1515B5 & 58 & 468 & 468 & 3.13 & 3.13 & 3.13 & 38,017 & 39,000 & 16.2 & 17.8 \\
\hline B1515B5Z & 29 & 464 & 465 & 3.2 & 3.22 & 3.23 & 36,016 & 42,328 & 17.7 & 19 \\
\hline B1515B6 & 130 & 462 & 464 & 3.22 & 3.47 & 3.66 & 41,790 & 49,383 & 16.7 & 19 \\
\hline B1515B7 & 96 & 463 & 465 & 3.48 & 3.51 & 3.55 & 42,059 & 48,738 & 17 & 18.4 \\
\hline $\mathrm{B} 1515 \mathrm{~B} 8$ & 798 & 465 & 469 & 3.29 & 3.65 & 4.01 & 42,692 & 54,000 & 8.9 & 17.8 \\
\hline B1515B9 & 276 & 464 & 468 & 3.29 & 3.96 & 4.76 & 44,097 & 53,952 & 11.2 & 16.7 \\
\hline B1515BGD & 4 & 430 & 430 & 3.92 & 3.92 & 3.92 & 49,027 & 58,310 & 22 & 23.3 \\
\hline B1515BZ & 848 & 463 & 466 & 3.05 & 3.47 & 4.68 & 37,441 & 54,023 & 9.3 & 24 \\
\hline B1515W & 8 & 462 & 465 & 3.9 & 4.06 & 4.22 & 36,993 & 49,075 & 11.3 & 17.3 \\
\hline B1717B & 4 & 457 & 458 & 2.64 & 2.84 & 3.04 & 29,517 & 33,904 & 29 & 30.8 \\
\hline C1414A & 1383 & 381 & 400 & 0.3 & 3.5 & 4.32 & 38,899 & 50,871 & 8.3 & 26.8 \\
\hline C1414C & 4198 & 382 & 409 & 1.03 & 3.2 & 4.48 & 33,597 & 56,000 & 8.9 & 36.5 \\
\hline C1414W & 552 & 403 & 412 & 2.7 & 3.15 & 3.76 & 30,039 & 37,781 & 14.1 & 27.6 \\
\hline C1616CSD & 4080 & 414 & 443 & 1.87 & 3.62 & 4.63 & 37,916 & 63,328 & 8.6 & 29.8 \\
\hline $\mathrm{C} 8016 \mathrm{C}$ & 2747 & 421 & 442 & 1.92 & 3.57 & 4.27 & 38,490 & 56,312 & 8.3 & 23.2 \\
\hline W1414A & 1018 & 378 & 407 & 0.71 & 3.42 & 4.5 & 37,500 & 56,328 & 9.3 & 33.7 \\
\hline W1414ATR & 288 & 363 & 368 & 2.39 & 3.38 & 3.57 & 38,168 & 46,000 & 18.9 & 26.3 \\
\hline W1414B & 2 & 383 & 383 & 3.22 & 3.22 & 3.22 & 24,398 & 24,465 & 33.7 & 33.7 \\
\hline W1414W & 603 & 394 & 404 & 2.26 & 3.04 & 3.47 & 27,315 & 39,723 & 24.8 & 39.9 \\
\hline W1414WL & 1429 & 399 & 406 & 2.27 & 3.07 & 3.41 & 31,940 & 47,932 & 16.7 & 38.3 \\
\hline W1414WO & 2108 & 356 & 369 & 0.99 & 3.92 & 4.95 & 44,730 & 69,452 & 8.1 & 27.8 \\
\hline W1515A & 889 & 429 & 435 & 2.01 & 3 & 3.6 & 33,344 & 49,859 & 11.3 & 31.7 \\
\hline W1515AHT & 308 & 435 & 438 & 3.51 & 4.08 & 4.59 & 45,441 & 56,922 & 8.2 & 15.7 \\
\hline W1515APL & 24 & 307 & 310 & 1.23 & 1.55 & 1.88 & 27,971 & 37,770 & 8.2 & 17.3 \\
\hline W1515W & 393 & 451 & 458 & 2.21 & 3 & 3.35 & 29,324 & 41,806 & 25 & 34.8 \\
\hline W1515WL & 4644 & 455 & 466 & 1.85 & 2.98 & 3.8 & 30,874 & 55,385 & 13.8 & 37.8 \\
\hline W1515WO & 3576 & 461 & 466 & 1.91 & 3.53 & 4.6 & 39,071 & 56,138 & 8.7 & 25.7 \\
\hline
\end{tabular}


Table A-5 (continued)

\begin{tabular}{|c|c|c|c|c|c|c|c|c|c|c|}
\hline \multirow{2}{*}{$\begin{array}{c}\text { Assembly } \\
\text { code }\end{array}$} & \multirow{2}{*}{$\begin{array}{l}\text { Number of } \\
\text { assemblies }\end{array}$} & \multicolumn{2}{|c|}{$\begin{array}{c}\text { Initial } \\
\text { uranium } \\
\text { loading } \\
\text { (kg/assembly) } \\
\end{array}$} & \multicolumn{3}{|c|}{$\begin{array}{l}\text { Enrichment } \\
\left(\mathbf{U}^{235} \text { wt \%) }\right.\end{array}$} & \multicolumn{2}{|c|}{$\begin{array}{c}\text { Burnup } \\
\text { (MWd/MTHM) }\end{array}$} & \multicolumn{2}{|c|}{$\begin{array}{l}\text { Cooling } \\
\text { time thru } \\
2010 \\
\text { (years) }\end{array}$} \\
\hline & & Avg. & Max. & Min. & Avg. & Max. & Avg. & Max. & Min. & Max. \\
\hline W1515WV5 & 531 & 458 & 463 & 2.99 & 3.92 & 4.8 & 37,556 & 53,056 & 8.2 & 15.3 \\
\hline W1717A & 1210 & 414 & 461 & 2.43 & 4.19 & 4.77 & 45,291 & 53,958 & 8.3 & 24.8 \\
\hline W1717B & 2060 & 456 & 467 & 2 & 3.84 & 4.6 & 40,741 & 54,014 & 8.3 & 19.3 \\
\hline W1717WL & 10097 & 461 & 469 & 1.6 & 3.12 & 4.4 & 32,340 & 58,417 & 8.7 & 32.8 \\
\hline W1717WO & 3204 & 425 & 459 & 1.6 & 3.05 & 4.02 & 32,690 & 53,000 & 8.8 & 26.9 \\
\hline W1717WP & 216 & 417 & 418 & 3.73 & 4.59 & 4.81 & 50,707 & 58,237 & 8.7 & 13.2 \\
\hline W1717WRF & 72 & 455 & 457 & 4 & 4.18 & 4.42 & 45,530 & 48,037 & 8.2 & 10.3 \\
\hline W1717WV & 24 & 425 & 426 & 4.21 & 4.38 & 4.41 & 44,263 & 48,385 & 11.2 & 11.2 \\
\hline W1717WV+ & 2126 & 424 & 465 & 1.61 & 4.16 & 4.66 & 45,430 & 61,685 & 8.2 & 16.3 \\
\hline W1717WV5 & 4469 & 424 & 431 & 1.49 & 4.01 & 4.95 & 43,872 & 56,570 & 8.3 & 22.3 \\
\hline W1717WVH & 3868 & 462 & 474 & 2.11 & 3.87 & 4.95 & 41,081 & 55,496 & 8.2 & 19.9 \\
\hline W1717WVJ & 104 & 462 & 465 & 3.71 & 3.99 & 4.4 & 43,922 & 46,847 & 8.8 & 10.3 \\
\hline WST17W & 1254 & 540 & 547 & 1.51 & 3.38 & 4.41 & 35,926 & 54,399 & 8.2 & 21.4 \\
\hline XFC14A & 192 & 353 & 359 & 3.5 & 3.57 & 3.8 & 37,205 & 46,048 & 18.9 & 26.8 \\
\hline XFC14C & 418 & 362 & 377 & 1.39 & 2.96 & 3.95 & 32,130 & 52,125 & 9.8 & 35.9 \\
\hline XFC14W & 229 & 374 & 376 & 0.27 & 3.75 & 4.25 & 38,521 & 51,971 & 8.7 & 14.2 \\
\hline XHN15B & 629 & 410 & 415 & 3 & 3.99 & 4.02 & 33,776 & 37,833 & 14.4 & 33.2 \\
\hline XHN15BZ & 104 & 364 & 368 & 3.4 & 3.8 & 3.91 & 34,278 & 42,956 & 14.4 & 21.3 \\
\hline XHN15HS & 1 & 406 & 406 & 3.99 & 3.99 & 3.99 & 32,151 & 32,151 & 35.6 & 35.6 \\
\hline XHN15HZ & 2 & 363 & 363 & 3.26 & 3.26 & 3.26 & 18,546 & 18,546 & 37.5 & 37.5 \\
\hline XHN15MS & 2 & 406 & 407 & 3.66 & 3.66 & 3.66 & 28,324 & 28,324 & 37.5 & 37.5 \\
\hline XHN15MZ & 2 & 371 & 371 & 2.95 & 2.95 & 2.95 & 25,643 & 25,643 & 37.5 & 37.5 \\
\hline XHN15W & 309 & 416 & 421 & 3.02 & 3.59 & 4 & 27,922 & 35,196 & 33.2 & 40.7 \\
\hline XHN15WZ & 53 & 385 & 387 & 4.2 & 4.39 & 4.6 & 14,321 & 19,376 & 14.4 & 14.4 \\
\hline XIP14W & 160 & 191 & 200 & 2.83 & 4.12 & 4.36 & 16,471 & 27,048 & 36.2 & 38 \\
\hline XPA15A & 808 & 397 & 408 & 1.5 & 3.17 & 4.05 & 34,362 & 51,486 & 9.8 & 33 \\
\hline XPA15C & 273 & 412 & 417 & 1.65 & 2.47 & 3.06 & 16,020 & 33,630 & 29.3 & 35 \\
\hline XSL16C & 909 & 381 & 394 & 1.72 & 3.44 & 4.28 & 38,807 & 54,838 & 9.1 & 26.2 \\
\hline XSO14W & 657 & 368 & 375 & 3.16 & 3.87 & 4.02 & 27,232 & 39,275 & 18.1 & 40.2 \\
\hline XSO14WD & 4 & 373 & 374 & 4.01 & 4.01 & 4.02 & 18,259 & 18,424 & 18.1 & 18.1 \\
\hline XSO14WM & 4 & 311 & 311 & 0.71 & 0.71 & 0.71 & 19,307 & 19,636 & 37.6 & 37.6 \\
\hline XYR16A & 228 & 234 & 237 & 3.49 & 3.78 & 4.02 & 29,034 & 35,088 & 23.7 & 32.2 \\
\hline XYR16C & 156 & 229 & 233 & 3.51 & 3.8 & 3.92 & 24,282 & 35,999 & 19.2 & 22.1 \\
\hline XYR16U & 73 & 239 & 241 & 3.96 & 3.99 & 4.02 & 27,461 & 31,986 & 33.6 & 36.6 \\
\hline
\end{tabular}


Table A-5 (continued)

\begin{tabular}{|c|c|c|c|c|c|c|c|c|c|c|}
\hline \multirow{2}{*}{$\begin{array}{c}\text { Assembly } \\
\text { code }\end{array}$} & \multirow{2}{*}{$\begin{array}{l}\text { Number of } \\
\text { assemblies }\end{array}$} & \multicolumn{2}{|c|}{$\begin{array}{c}\text { Initial } \\
\text { uranium } \\
\text { loading } \\
\text { (kg/assembly) } \\
\end{array}$} & \multicolumn{3}{|c|}{$\begin{array}{l}\text { Enrichment } \\
\left(\mathrm{U}^{235} \text { wt \%) }\right.\end{array}$} & \multicolumn{2}{|c|}{$\begin{array}{c}\text { Burnup } \\
\text { (MWd/MTHM) }\end{array}$} & \multicolumn{2}{|c|}{$\begin{array}{c}\text { Cooling } \\
\text { time thru } \\
2010 \\
\text { (years) } \\
\end{array}$} \\
\hline & & Avg. & Max. & Min. & Avg. & Max. & Avg. & Max. & Min. & Max. \\
\hline XYR18W & 76 & 273 & 274 & 4.94 & 4.94 & 4.94 & 25,484 & 31,755 & 35.2 & 38.9 \\
\hline
\end{tabular}


Table A-6. Summary of UNF characteristics from which representative samples may be selected for BWR fuel assemblies [Ref. 5]

\begin{tabular}{|c|c|c|c|c|c|c|c|c|c|c|}
\hline \multirow{2}{*}{$\begin{array}{c}\text { Assembly } \\
\text { code }\end{array}$} & \multirow{2}{*}{$\begin{array}{l}\text { Number of } \\
\text { assemblies }\end{array}$} & \multicolumn{2}{|c|}{$\begin{array}{c}\text { Initial } \\
\text { uranium } \\
\text { loading } \\
\text { (kg/assembly) }\end{array}$} & \multicolumn{3}{|c|}{$\begin{array}{l}\text { Enrichment } \\
\left(\mathbf{U}^{235} \text { wt \%) }\right.\end{array}$} & \multicolumn{2}{|c|}{$\begin{array}{c}\text { Burnup } \\
\text { (MWd/MTHM) }\end{array}$} & \multicolumn{2}{|c|}{$\begin{array}{l}\text { Cooling time } \\
\text { thru 2010 } \\
\text { (years) }\end{array}$} \\
\hline & & Avg. & Max. & Min. & Avg. & Max. & Avg. & Max. & Min. & Max. \\
\hline 9X9IXQFA & 8 & 171 & 171 & 3.25 & 3.25 & 3.25 & 39166 & 39248 & 11 & 11 \\
\hline ATRIUM10 & 128 & 177 & 177 & 3.94 & 3.94 & 3.94 & 38406 & 39000 & 9.8 & 9.8 \\
\hline G2307A & 152 & 182 & 184 & 2.56 & 2.64 & 2.65 & 24256 & 27826 & 31 & 33.7 \\
\hline G2307G2A & 1672 & 195 & 198 & 2.07 & 2.1 & 2.11 & 16775 & 24902 & 31.7 & 39.3 \\
\hline G2307G2B & 5047 & 193 & 197 & 1.65 & 2.15 & 2.62 & 16384 & 29728 & 29.3 & 40.6 \\
\hline G2307G3 & 395 & 187 & 189 & 1.96 & 2.41 & 2.6 & 25420 & 38861 & 26.7 & 35.3 \\
\hline G2308A & 1517 & 175 & 184 & 2.39 & 2.66 & 3.13 & 28814 & 36826 & 18 & 32.3 \\
\hline G2308AP & 32 & 173 & 173 & 2.82 & 2.83 & 2.83 & 34366 & 34826 & 16.8 & 16.8 \\
\hline G2308G10 & 1404 & 172 & 174 & 3.1 & 3.25 & 3.56 & 33988 & 43977 & 8.2 & 15.2 \\
\hline G2308G4 & 3944 & 184 & 185 & 2.19 & 2.51 & 2.76 & 26087 & 40523 & 23.2 & 32.2 \\
\hline G2308G5 & 810 & 177 & 178 & 2.39 & 2.66 & 2.82 & 29009 & 33597 & 19.9 & 28.3 \\
\hline G2308G7 & 164 & 179 & 179 & 2.96 & 2.97 & 2.99 & 31570 & 35894 & 15.9 & 15.9 \\
\hline G2308G8A & 1150 & 176 & 180 & 2.55 & 3.09 & 3.4 & 34848 & 44933 & 12.1 & 19.8 \\
\hline G2308G8B & 1382 & 173 & 178 & 2.96 & 3.19 & 3.39 & 36400 & 42518 & 10.2 & 17.9 \\
\hline G2308G9 & 890 & 172 & 173 & 2.85 & 3.18 & 3.48 & 37268 & 42295 & 8.2 & 14.7 \\
\hline G2308GB & 1367 & 178 & 180 & 2.62 & 2.8 & 3.39 & 32014 & 43381 & 13.8 & 25 \\
\hline G2308GP & 3281 & 177 & 179 & 2.08 & 2.77 & 3.01 & 29317 & 38139 & 15.8 & 25.8 \\
\hline G2309A & 1820 & 168 & 170 & 2.78 & 3.1 & 3.15 & 35941 & 40818 & 8.2 & 20.3 \\
\hline G2309AIX & 224 & 169 & 170 & 3.25 & 3.31 & 3.82 & 39151 & 43778 & 8.2 & 9.2 \\
\hline G2309G11 & 132 & 166 & 170 & 3.1 & 3.56 & 3.78 & 40522 & 45117 & 9.2 & 13.8 \\
\hline G4607G2 & 1142 & 195 & 197 & 1.09 & 1.56 & 2.5 & 9362 & 11829 & 31.7 & 37.3 \\
\hline G4607G3A & 3752 & 187 & 189 & 1.1 & 2.33 & 2.51 & 21058 & 32188 & 25.1 & 35.6 \\
\hline G4607G3B & 1184 & 190 & 192 & 1.1 & 2.31 & 2.51 & 21948 & 30831 & 28.6 & 34.3 \\
\hline G4608AP & 1888 & 176 & 177 & 2.62 & 2.88 & 3.4 & 31248 & 35518 & 13.8 & 21.8 \\
\hline G4608G10 & 2337 & 178 & 186 & 2.63 & 3.24 & 3.7 & 36695 & 44343 & 8.7 & 17.8 \\
\hline G4608G11 & 236 & 171 & 171 & 3.38 & 3.38 & 3.38 & 35194 & 42551 & 9.9 & 11.8 \\
\hline G4608G12 & 88 & 181 & 181 & 3.69 & 3.71 & 3.99 & 32069 & 34462 & 9.9 & 11.8 \\
\hline G4608G4A & 1785 & 184 & 185 & 2.19 & 2.62 & 2.99 & 24931 & 43430 & 18.8 & 33.4 \\
\hline G4608G4B & 560 & 187 & 188 & 2.1 & 2.31 & 2.76 & 21362 & 32941 & 25.8 & 32 \\
\hline G4608G5 & 4213 & 183 & 185 & 0.7 & 2.36 & 3.01 & 23964 & 38224 & 14.9 & 31 \\
\hline G4608G8 & 3919 & 180 & 186 & 2.95 & 3.19 & 3.4 & 34905 & 44640 & 9.3 & 20.3 \\
\hline G4608G9 & 7146 & 178 & 186 & 1.51 & 3.23 & 3.88 & 36492 & 47062 & 8.2 & 18.3 \\
\hline G4608GB & 10246 & 185 & 187 & 0.71 & 2.53 & 3.25 & 26297 & 45986 & 10.2 & 26.3 \\
\hline G4608GP & 12642 & 183 & 187 & 0.7 & 2.38 & 3.27 & 23112 & 42428 & 8.8 & 29.8 \\
\hline G4608W & 8 & 157 & 171 & 2.69 & 2.85 & 3.01 & 28041 & 33140 & 14.8 & 19.1 \\
\hline G4609A & 3280 & 173 & 175 & 0.72 & 3.42 & 3.73 & 36933 & 47000 & 8.8 & 21.3 \\
\hline G4609A5 & 1124 & 176 & 177 & 2.9 & 3.28 & 3.55 & 36536 & 43555 & 9.7 & 17.3 \\
\hline G4609A9X & 768 & 169 & 177 & 2.53 & 2.87 & 3.11 & 36880 & 43330 & 9.6 & 15.7 \\
\hline G4609AIX & 12 & 175 & 177 & 3 & 3.58 & 3.94 & 24156 & 36777 & 8.2 & 17.3 \\
\hline G4609AX+ & 8 & 167 & 167 & 3.13 & 3.14 & 3.15 & 39239 & 40457 & 13.9 & 14.3 \\
\hline G4609G11 & 5351 & 170 & 178 & 1.46 & 3.56 & 4.14 & 40351 & 65149 & 8.3 & 16.9 \\
\hline G4609G13 & 2060 & 171 & 173 & 3.24 & 3.85 & 4.17 & 42045 & 53636 & 8.2 & 14.8 \\
\hline G4610A & 116 & 177 & 177 & 3.94 & 3.94 & 3.94 & 38207 & 39000 & 8.8 & 8.8 \\
\hline G4610AIX & 4 & 175 & 175 & 3.39 & 3.39 & 3.39 & 37706 & 38009 & 10.2 & 10.2 \\
\hline G4610C & 148 & 176 & 176 & 2.51 & 3.29 & 3.62 & 38133 & 42640 & 9.6 & 14.8 \\
\hline G4610G12 & 371 & 176 & 182 & 3.12 & 3.98 & 4.2 & 44175 & 52735 & 8.2 & 10.3 \\
\hline
\end{tabular}


Table A-6 (continued)

\begin{tabular}{|c|c|c|c|c|c|c|c|c|c|c|}
\hline \multirow{2}{*}{$\begin{array}{c}\text { Assembly } \\
\text { code }\end{array}$} & \multirow{2}{*}{$\begin{array}{l}\text { Number of } \\
\text { assemblies }\end{array}$} & \multicolumn{2}{|c|}{$\begin{array}{c}\text { Initial } \\
\text { uranium } \\
\text { loading } \\
\text { (kg/assembly) }\end{array}$} & \multicolumn{3}{|c|}{$\begin{array}{l}\text { Enrichment } \\
\left(\mathbf{U}^{235} \text { wt \%) }\right.\end{array}$} & \multicolumn{2}{|c|}{$\begin{array}{c}\text { Burnup } \\
\text { (MWd/MTHM) }\end{array}$} & \multicolumn{2}{|c|}{$\begin{array}{c}\text { Cooling time } \\
\text { thru 2010 } \\
\text { (years) }\end{array}$} \\
\hline & & Avg. & Max. & Min. & Avg. & Max. & Avg. & Max. & Min. & Max. \\
\hline G4610G14 & 5 & 179 & 180 & 4.01 & 4.11 & 4.24 & 5868 & 8915 & 8.2 & 8.7 \\
\hline XBR07G & 4 & 132 & 133 & 2.88 & 2.88 & 2.88 & 1643 & 1690 & 42.5 & 42.5 \\
\hline XBR08G & 2 & 113 & 113 & 2.85 & 2.85 & 2.85 & 4546 & 7027 & 41.7 & 42.5 \\
\hline XBR09A & 4 & 128 & 131 & 3.45 & 3.48 & 3.52 & 20981 & 22811 & 33.4 & 34.9 \\
\hline XBR09G & 143 & 137 & 141 & 3.51 & 3.58 & 3.62 & 15092 & 22083 & 30.2 & 39.9 \\
\hline XBR11A & 360 & 130 & 133 & 3.13 & 3.42 & 3.82 & 22716 & 34212 & 13.3 & 31.9 \\
\hline XBR11G & 6 & 125 & 132 & 3.11 & 3.46 & 3.63 & 22802 & 24997 & 38.8 & 38.8 \\
\hline XBR11N & 8 & 129 & 134 & 2.16 & 2.83 & 3.51 & 18940 & 21850 & 33.4 & 36.6 \\
\hline XDR06A & 66 & 95 & 95 & 2.23 & 2.23 & 2.24 & 4907 & 5742 & 32.2 & 32.2 \\
\hline XDR06G & 1 & 111 & 111 & 1.47 & 1.47 & 1.47 & 23522 & 23522 & 41.3 & 41.3 \\
\hline XDR06G3B & 163 & 102 & 103 & 1.83 & 1.83 & 1.83 & 18632 & 27106 & 33.5 & 41.3 \\
\hline XDR06G3F & 96 & 102 & 103 & 2.25 & 2.25 & 2.25 & 22132 & 28138 & 33.5 & 41.3 \\
\hline XDR06G5 & 106 & 106 & 112 & 2.26 & 2.26 & 2.26 & 21095 & 25886 & 32.2 & 41.3 \\
\hline XDR06U & 458 & 102 & 103 & 1.83 & 2.24 & 2.26 & 17685 & 26396 & 32.2 & 41.3 \\
\hline XDR07GS & 1 & 59 & 59 & 3.1 & 3.1 & 3.1 & 29000 & 29000 & 41.3 & 41.3 \\
\hline XDR08G & 1 & 100 & 100 & 1.95 & 1.95 & 1.95 & 25287 & 25287 & 41.3 & 41.3 \\
\hline ХHB06A & 126 & 70 & 74 & 2.35 & 2.4 & 2.41 & 9037 & 22377 & 34.5 & 35.6 \\
\hline XHB06G & 176 & 76 & 77 & 2.35 & 2.43 & 2.52 & 17170 & 22876 & 34.5 & 39.6 \\
\hline XHB07G2 & 88 & 76 & 77 & 2.08 & 2.11 & 2.31 & 18187 & 20770 & 37.3 & 39.6 \\
\hline XLC10A & 178 & 109 & 110 & 3.68 & 3.69 & 3.71 & 15017 & 20126 & 23.7 & 28.7 \\
\hline XLC10L & 156 & 120 & 121 & 3.63 & 3.77 & 3.94 & 14419 & 21532 & 28.7 & 41.2 \\
\hline
\end{tabular}



APPENDIX B

DOE-OWNED USED NUCLEAR FUEL CHARACTERISTICS

B-1 
Table B-1. Ranges of nominal properties for DOE-owned used nuclear fuel [Ref. 3]

\begin{tabular}{|c|c|c|c|c|c|c|c|c|c|}
\hline Fuel group & МТНМ $^{a}$ & \begin{tabular}{|c|}
$\begin{array}{c}\text { EOL effective } \\
\text { enrichment } \\
(\%)\end{array}$ \\
\end{tabular} & $\begin{array}{l}\text { Cladding } \\
\text { composition }\end{array}$ & $\begin{array}{l}\text { Cladding } \\
\text { condition }\end{array}$ & $\begin{array}{c}\text { Fuel } \\
\text { compound } \\
\text { names }\end{array}$ & $\begin{array}{c}\text { Fuel } \\
\text { matrix }\end{array}$ & Configuration & $\begin{array}{l}\text { Length } \\
\text { (ft) }\end{array}$ & $\begin{array}{c}\text { Width/ } \\
\text { height/ } \\
\text { diameter } \\
\text { (in.) }\end{array}$ \\
\hline 01. U metal, zirc clad, LEU & 2103 & $1.7-0.5$ & Zirconium & $\begin{array}{l}\text { Fair } \\
\text { Poor }\end{array}$ & U metal & None & $\begin{array}{l}\text { Plates } \\
\text { Tubes }\end{array}$ & $2.1-9.9$ & $1.0-4.3$ \\
\hline $\begin{array}{l}\text { 02. U metal, nonzirc clad, } \\
\text { LEU }\end{array}$ & 8 & $3.4-0.2$ & $\begin{array}{c}\text { SST } \\
\text { Aluminum }\end{array}$ & $\begin{array}{l}\text { Poor } \\
\text { Good } \\
\text { Fair }\end{array}$ & U metal & None & $\begin{array}{c}\text { Cans of scrap } \\
\text { Tubes } \\
\text { None }\end{array}$ & $0.6-0.9$ & $1.4-1.9$ \\
\hline 03. U-zirc & $<1$ & $92.9-0.5$ & Zirconium & $\begin{array}{l}\text { Fair } \\
\text { Good }\end{array}$ & $\begin{array}{l}\text { U metal } 2 \% \mathrm{Zr} \\
\mathrm{U}-\mathrm{Zr}\end{array}$ & None & $\begin{array}{c}\text { Tube } \\
\text { Cylinders } \\
\text { Plates } \\
\end{array}$ & $2.0-12.5$ & $2.0-7.4$ \\
\hline 04. U-Mo & 4 & $25.8-2.4$ & $\begin{array}{l}\text { Zirconium } \\
\text { Aluminum } \\
\text { None }\end{array}$ & $\begin{array}{l}\text { Good } \\
\text { Poor } \\
\text { Fair } \\
\text { None }\end{array}$ & U-Mo & None & $\begin{array}{c}\text { Rod } \\
\text { Tube } \\
\text { Plates in can }\end{array}$ & $1.0-3.8$ & $0.1-2.1$ \\
\hline $\begin{array}{l}\text { 05. U oxide, zirc clad, intact, } \\
\text { HEU }\end{array}$ & $<1$ & $92.5-23.1$ & Zirconium & $\begin{array}{l}\text { Fair } \\
\text { Good }\end{array}$ & $\mathrm{UO}_{2}$ & $\begin{array}{c}\mathrm{ZrO}_{2}-\mathrm{CaO} \\
\text { Graphite } \\
\mathrm{ZrO}_{2} \\
\end{array}$ & $\begin{array}{c}\text { Rod } \\
\text { Assembly } \\
\text { Plates }\end{array}$ & $3.1-9.0$ & $0.3-7.4$ \\
\hline $\begin{array}{l}\text { 06. U oxide, zirc clad, intact, } \\
\text { MEU }\end{array}$ & 2 & $6.9-5$ & Zirconium & $\begin{array}{l}\text { Fair } \\
\text { Good }\end{array}$ & $\mathrm{UO}_{2}$ & None & $\begin{array}{c}\text { Plates } \\
\text { Rod } \\
\text { Cans of rods } \\
\text { Element }\end{array}$ & $2.9-5.2$ & $0.3-3.8$ \\
\hline $\begin{array}{l}\text { 07. U oxide, zirc clad, intact, } \\
\text { LEU }\end{array}$ & 90 & $4.9 \%-0.6$ & Zirconium & $\begin{array}{l}\text { Good } \\
\text { Fair }\end{array}$ & $\mathrm{UO}_{2}$ & None & $\begin{array}{c}\text { Tubes } \\
\text { Rod } \\
\text { Plates } \\
\text { Assembly }\end{array}$ & $0.8-14.7$ & $0.4-8.5$ \\
\hline $\begin{array}{l}\text { 08. U oxide, SST/hastelloy } \\
\text { clad, intact, HEU }\end{array}$ & $<1$ & $93.2-91.0$ & $\begin{array}{c}\text { SST } \\
\text { Hastelloy }\end{array}$ & $\begin{array}{l}\text { Good } \\
\text { Fair }\end{array}$ & $\begin{array}{l}\text { U oxide } \\
\mathrm{UO}_{2}\end{array}$ & $\begin{array}{c}\text { SST } \\
\text { SST } \\
(316 \mathrm{~L}) \\
\text { SST 304B } \\
\text { SST 304 } \\
\text { None }\end{array}$ & $\begin{array}{c}\text { Tubes } \\
\text { Cans of scrap } \\
\text { Rod } \\
\text { Plates } \\
\text { Rod assembly }\end{array}$ & $2.1-6.6$ & $0.9-3.7$ \\
\hline $\begin{array}{l}\text { 09. U oxide, SST clad, intact, } \\
\text { MEU }\end{array}$ & $<1$ & $20.0-5.5$ & SST & $\begin{array}{l}\text { Good } \\
\text { Fair }\end{array}$ & $\begin{array}{c}\mathrm{UO}_{2}-\mathrm{BeO}_{2} \\
\mathrm{UO}_{2}\end{array}$ & $\begin{array}{l}\mathrm{ZrO}_{2}-\mathrm{CaO} \\
\quad \text { None }\end{array}$ & $\begin{array}{c}\text { Rod } \\
\text { Element }\end{array}$ & $2.4-4.0$ & $0.3-1.5$ \\
\hline $\begin{array}{l}\text { 10. U oxide, SST clad, intact, } \\
\text { LEU }\end{array}$ & $<1$ & $1.9-0.2$ & SST & $\begin{array}{l}\text { Good } \\
\text { Fair }\end{array}$ & $\mathrm{UO}_{2}$ & None & $\begin{array}{l}\text { Tube } \\
\text { Rod }\end{array}$ & $1.5-12.0$ & $0.4-8.5$ \\
\hline
\end{tabular}


Table B-1 (continued)

\begin{tabular}{|c|c|c|c|c|c|c|c|c|c|}
\hline Fuel group & МТНМ $^{a}$ & $\begin{array}{c}\text { EOL effective } \\
\text { enrichment } \\
(\%)\end{array}$ & $\begin{array}{l}\text { Cladding } \\
\text { composition }\end{array}$ & $\begin{array}{l}\text { Cladding } \\
\text { condition }\end{array}$ & $\begin{array}{l}\text { Fuel } \\
\text { compound } \\
\text { names }\end{array}$ & $\begin{array}{c}\text { Fuel } \\
\text { matrix }\end{array}$ & Configuration & $\begin{array}{l}\text { Length } \\
\text { (ft) }\end{array}$ & $\begin{array}{l}\text { Width/ } \\
\text { height/ } \\
\text { diameter } \\
\text { (in.) }\end{array}$ \\
\hline $\begin{array}{l}\text { 11. U oxide, nonalum clad, } \\
\text { nonintact or declad, HEU }\end{array}$ & $<1$ & $93.3-21.0$ & $\begin{array}{l}\text { Nichrome } \\
\text { Hastelloy } \\
\text { SST } \\
\text { Zirconium } \\
\text { None }\end{array}$ & $\begin{array}{l}\text { Poor } \\
\text { None }\end{array}$ & $\mathrm{UO}_{2}$ & $\begin{array}{c}\text { BEO } \\
\text { SST } \\
\text { Nichrome } \\
\text { None }\end{array}$ & Cans of scrap & $0.2-2.8$ & $2.8-5.6$ \\
\hline $\begin{array}{l}\text { 12. U oxide, nonalum clad, } \\
\text { nonintact or declad, MEU }\end{array}$ & $<1$ & $18.6-5.2$ & $\begin{array}{l}\text { None } \\
\text { Zirconium } \\
\text { SST }\end{array}$ & Poor & $\mathrm{UO}_{2}$ & $\begin{array}{l}\mathrm{Gd}_{2} \mathrm{O}_{3} \\
\text { None } \\
\text { SST }\end{array}$ & $\begin{array}{l}\text { Experiment } \\
\text { capsule } \\
\text { Scrap } \\
\text { Cans of scrap }\end{array}$ & $3.4-9.9$ & $0.4-9.1$ \\
\hline $\begin{array}{l}\text { 13. U oxide, nonalum clad, } \\
\text { nonintact or declad, LEU }\end{array}$ & 83 & $3.2-1.1$ & $\begin{array}{l}\text { Zirconium } \\
\text { SST }\end{array}$ & Poor & $\mathrm{UO}_{2}$ & None & $\begin{array}{c}\text { Cans of scrap } \\
\text { Scrap } \\
\text { Rod } \\
\end{array}$ & $12.4-13.5$ & $0.5-14.0$ \\
\hline 14. U oxide, alum clad, HEU & 5 & $89.9-58.1$ & Aluminum & $\begin{array}{l}\text { Good } \\
\text { Fair }\end{array}$ & $\mathrm{U}_{3} \mathrm{O}_{8}$ & Alum & Plates & $2.0-3.6$ & $2.8-17.2$ \\
\hline $\begin{array}{l}\text { 15. U oxide, alum clad, MEU } \\
\text { and LEU }\end{array}$ & $<1$ & $20.0-8.9$ & Aluminum & $\begin{array}{l}\text { Good } \\
\text { Fair }\end{array}$ & $\mathrm{U}_{3} \mathrm{O}_{8}$ & Alum & $\begin{array}{c}\text { Plates } \\
\text { Assembly }\end{array}$ & $2.2-3.3$ & $3.0-4.8$ \\
\hline 16. U-ALx, HEU & 8 & $93.3-21.9$ & Aluminum & $\begin{array}{l}\text { Good } \\
\text { Fair }\end{array}$ & U-ALx & Alum & $\begin{array}{c}\text { Rods } \\
\text { Tubes } \\
\text { Plates } \\
\text { Pin cluster } \\
\text { Assemblies } \\
\text { Elements }\end{array}$ & $0.4-10.1$ & $1.3-16.3$ \\
\hline 17. U-ALx, MEU & 3 & $20.0-9.0$ & Aluminum & $\begin{array}{l}\text { Good } \\
\text { Fair }\end{array}$ & U-ALX & Alum & $\begin{array}{c}\text { Assembly } \\
\text { Element } \\
\text { Plates } \\
\end{array}$ & $2.0-3.4$ & $2.1-4.1$ \\
\hline 18. U3Si2 & 8 & $22.0-5.2$ & Aluminum & $\begin{array}{l}\text { Good } \\
\text { Fair } \\
\text { Poor }\end{array}$ & $\mathrm{U}_{3} \mathrm{SI}_{2}$ & Alum & $\begin{array}{c}\text { Tubes } \\
\text { Multi-pin cluster } \\
\text { Assembly } \\
\text { Cans of Scrap } \\
\end{array}$ & $2.0-3.4$ & $2.6-4.1$ \\
\hline $\begin{array}{l}\text { 19. Th/U carbide, TRISO or } \\
\text { BISO coated particles in } \\
\text { graphite }^{b}\end{array}$ & 25 & $84.4-71.4$ & $\begin{array}{c}\text { BISC } \\
\text { TRISO }\end{array}$ & Good & $\begin{array}{l}\mathrm{ThC}_{2}-\mathrm{UC}_{2} \\
\text { ThC-UC }\end{array}$ & Graphite & $\begin{array}{c}\text { Tubes } \\
\text { Cans of scrap }\end{array}$ & $2.6-10.5$ & $3.5-14.2$ \\
\hline
\end{tabular}


Table B-1 (continued)

\begin{tabular}{|c|c|c|c|c|c|c|c|c|c|}
\hline Fuel group & МТНМ $^{a}$ & $\begin{array}{c}\text { EOL effective } \\
\text { enrichment } \\
(\%)\end{array}$ & $\begin{array}{l}\text { Cladding } \\
\text { composition }\end{array}$ & $\begin{array}{l}\text { Cladding } \\
\text { condition }\end{array}$ & $\begin{array}{l}\text { Fuel } \\
\text { compound } \\
\text { names }\end{array}$ & $\begin{array}{c}\text { Fuel } \\
\text { matrix }\end{array}$ & Configuration & $\begin{array}{l}\text { Length } \\
\text { (ft) }\end{array}$ & $\begin{array}{l}\text { Width/ } \\
\text { height/ } \\
\text { diameter } \\
\text { (in.) }\end{array}$ \\
\hline $\begin{array}{l}\text { 20. Th/U carbide, mono- } \\
\text { pyrolytic carbon coated } \\
\text { particles in graphite }{ }^{b}\end{array}$ & 2 & $93.2-80.6$ & $\begin{array}{l}\text { Mono-pyrolytic } \\
\text { carbon }\end{array}$ & Poor & $\begin{array}{l}\text { ThCO-UCO } \\
\text { ThC }_{2}-\mathrm{UC}_{2}\end{array}$ & Graphite & $\begin{array}{c}\text { Element } \\
\text { Carbon coated } \\
\text { part } \\
\text { Cans of Scrap }\end{array}$ & $\sim 12.0$ & $\sim 3.5$ \\
\hline \begin{tabular}{|l} 
21. \\
$\mathrm{Pu} / \mathrm{U}$ carbide, \\
nongraphite clad, not \\
sodium bonded
\end{tabular} & $<1$ & $67.3-1$ & SST & $\begin{array}{l}\text { Good } \\
\text { Fair } \\
\text { Poor }\end{array}$ & $\mathrm{Pu} / \mathrm{U}$ carbide & None & $\begin{array}{c}\text { Element } \\
\text { Cans of scrap } \\
\text { Rod }\end{array}$ & $7.7-12.0$ & $0.2-5.2$ \\
\hline 22. MOX, zirc clad & 2 & $21.3-1.3$ & Zirconium & $\begin{array}{l}\text { Poor } \\
\text { Good } \\
\text { Fair }\end{array}$ & $\mathrm{PuO}_{2}-\mathrm{UO}_{2}$ & None & $\begin{array}{c}\text { Rod } \\
\text { Cans of Scrap } \\
\text { Plates } \\
\text { Element }\end{array}$ & $3.3-7.1$ & $0.3-6.6$ \\
\hline 23. MOX, SST clad & 11 & $87.4-2.1$ & SST & $\begin{array}{l}\text { Poor } \\
\text { Good } \\
\text { Fair }\end{array}$ & $\begin{array}{c}\mathrm{PuO}_{2}-\mathrm{UO}_{2} \\
\mathrm{PuO}_{2}\end{array}$ & None & $\begin{array}{c}\text { Rod } \\
\text { Plates } \\
\text { Element } \\
\text { Cans of Scrap } \\
\text { Scrap }\end{array}$ & $1.1-12.0$ & $0.2-9.1$ \\
\hline $\begin{array}{l}\text { 24. MOX, non-SST/nonzirc } \\
\text { clad }\end{array}$ & $<1$ & $54.3-5$ & Unknown & $\begin{array}{l}\text { N/A } \\
\text { Poor }\end{array}$ & $\mathrm{PuO}_{2}-\mathrm{UO}_{2}$ & $\begin{array}{c}\text { None } \\
\text { Unknown }\end{array}$ & $\begin{array}{c}\text { Scrap } \\
\text { Cans of scrap }\end{array}$ & Unknown & Unknown \\
\hline 25. $\mathrm{Th} / \mathrm{U}$ oxide, zirc clad & 43 & $98.4-10.1$ & Zirconium & $\begin{array}{l}\text { Good } \\
\text { Poor } \\
\text { N/A }\end{array}$ & $\begin{array}{c}\mathrm{ThO}_{2}-\mathrm{UO}_{2} \\
\text { ceramic }\end{array}$ & None & $\begin{array}{c}\text { Rod } \\
\text { Assembly } \\
\text { Cans of scrap }\end{array}$ & $\sim 11.8$ & $9.0-22.3$ \\
\hline 26. $\mathrm{Th} / \mathrm{U}$ oxide, $\mathrm{SST}$ clad & 8 & $97.8-7.6$ & SST & $\begin{array}{l}\text { Fair } \\
\text { Good } \\
\text { Poor }\end{array}$ & $\mathrm{ThO}_{2}-\mathrm{UO}_{2}$ & None & $\begin{array}{c}\text { Assembly } \\
\text { Cans of scrap } \\
\text { Rod }\end{array}$ & $5.2-11.7$ & $0.4-11.9$ \\
\hline $\begin{array}{l}\text { 27. U-zirc hydride, } \\
\text { SST/incoloy clad, HEU }\end{array}$ & $<1$ & $93.2-42.5$ & $\begin{array}{c}\text { SST } \\
\text { Incoloy }\end{array}$ & $\begin{array}{l}\text { Good } \\
\text { Fair }\end{array}$ & U-ZrHX-Er & None & $\begin{array}{c}\text { Rod } \\
\text { Element }\end{array}$ & $2.4-3.8$ & $0.5-3.2$ \\
\hline $\begin{array}{ll}\text { 28. U-zirc hydride, } \\
\text { SST/incoloy clad, MEU }\end{array}$ & 2 & $20.0-11.9$ & $\begin{array}{c}\text { SST } \\
\text { Incoloy } \\
\end{array}$ & $\begin{array}{l}\text { Good } \\
\text { Poor }\end{array}$ & $\begin{array}{c}\mathrm{U}-\mathrm{ZrHX} \\
\mathrm{U}-\mathrm{ZrHX}-\mathrm{Er}\end{array}$ & None & $\begin{array}{c}\text { Element } \\
\text { Canister of scrap }\end{array}$ & $2.4-3.8$ & $\sim 1.5$ \\
\hline $\begin{array}{l}\text { 29. U-zirc hydride, alum } \\
\text { clad, MEU }\end{array}$ & $<1$ & $20.0-16.8$ & Aluminum & Good & U-ZrHX & None & Element & $\sim 2.4$ & $\sim 1.5$ \\
\hline 30. U-zirc hydride, declad & $<1$ & $\sim 89.7$ & None & $\mathrm{N} / \mathrm{A}$ & U-ZrHX & None & Declad rod & $\sim 1.2$ & $\sim 1.2$ \\
\hline
\end{tabular}


Table B-1 (continued)

\begin{tabular}{|c|c|c|c|c|c|c|c|c|c|}
\hline Fuel group & МТНМ $^{a}$ & $\begin{array}{c}\text { EOL effective } \\
\text { enrichment } \\
(\%)\end{array}$ & $\begin{array}{l}\text { Cladding } \\
\text { composition }\end{array}$ & $\begin{array}{l}\text { Cladding } \\
\text { condition }\end{array}$ & $\begin{array}{c}\text { Fuel } \\
\text { compound } \\
\text { names }\end{array}$ & $\begin{array}{c}\text { Fuel } \\
\text { matrix }\end{array}$ & Configuration & $\begin{array}{l}\text { Length } \\
\text { (ft) }\end{array}$ & $\begin{array}{c}\text { Width/ } \\
\text { height/ } \\
\text { diameter } \\
\text { (in.) }\end{array}$ \\
\hline 31. Metallic sodium bonded & 60 & $93.2-<0.1$ & $\begin{array}{c}\text { SST } \\
\text { None } \\
\text { Unknown }\end{array}$ & $\begin{array}{l}\text { Poor } \\
\text { Good } \\
\text { N/A } \\
\text { Fair }\end{array}$ & $\begin{array}{c}\mathrm{PuO}_{2}-\mathrm{UO}_{2} \\
\mathrm{U}-10 \mathrm{Zr} \\
\mathrm{U}-\mathrm{Mo} \\
\mathrm{U}-10 \mathrm{Zr} \\
\mathrm{U} \text { metal } \\
\mathrm{U}-\mathrm{Pu}-\mathrm{Zr} \\
\mathrm{UO}_{2} \\
\mathrm{U} \text { metal } \\
\mathrm{Pu} / \mathrm{U} \text { alloy } \\
\mathrm{U}-5 \text { fissium } \\
\mathrm{Pu} / \mathrm{U} \text { carbide }\end{array}$ & None & $\begin{array}{c}\text { Fuel in sodium } \\
\text { Rod } \\
\text { Assembly } \\
\text { Cans of Scrap } \\
\text { Scrap }\end{array}$ & $1.8-12.0$ & $0.2-9.1$ \\
\hline 32. Naval & 65 & - & - & - & - & - & - & - & - \\
\hline 33. Canyon stabilization & $\mathrm{N} / \mathrm{A}$ & - & - & - & - & - & - & - & - \\
\hline $\begin{array}{l}\text { 34. Misc (not previously } \\
\text { listed) }\end{array}$ & $<1$ & $90.0-14.6$ & $\begin{array}{c}\text { None } \\
\text { Zirconium } \\
\text { Unknown } \\
\text { Aluminum } \\
\text { SST }\end{array}$ & $\begin{array}{l}\text { Fair } \\
\text { Poor } \\
\text { N/A } \\
\text { Good }\end{array}$ & $\begin{array}{c}\mathrm{ThO}_{2}-\mathrm{UO}_{2} \\
\mathrm{U}-\mathrm{Th} \text { metal } \\
\mathrm{U} \text { metal } \\
\text { Am oxide } \\
\mathrm{Pu} / \mathrm{U} \text { nitride }\end{array}$ & $\begin{array}{l}\text { None } \\
\text { Alum } \\
(1100) \\
\text { Unknown }\end{array}$ & $\begin{array}{c}\text { Cans of scrap } \\
\text { Tube } \\
\text { Rod }\end{array}$ & $0.3-9.9$ & $0.5-2.6$ \\
\hline
\end{tabular}

${ }^{a}$ MTHM are rounded to next higher whole number or reported as $<1$ MTHM, as applicable.

${ }^{b}$ For fuel groups 19 and 20, cladding composition and cladding condition are reporting particle coating composition and condition.

Group 31 is sodium-bonded fuel. Some of this material has been or will be treated into HLW.

Group 33 will be processed into HLW. 
